Florida International University FIU Digital Commons

\title{
Gammaridean Amphipods as Bioindicators in Subtropical Seagrass Ecosystems
}

Jennifer L. Sweatman

Florida International University, jswea001@fiu.edu

DOI: 10.25148 /etd.FIDC000721

Follow this and additional works at: https://digitalcommons.fiu.edu/etd

Part of the Biology Commons

\section{Recommended Citation}

Sweatman, Jennifer L., "Gammaridean Amphipods as Bioindicators in Subtropical Seagrass Ecosystems" (2016). FIU Electronic Theses and Dissertations. 2603.

https://digitalcommons.fiu.edu/etd/2603 


\section{FLORIDA INTERNATIONAL UNIVERSITY}

Miami, Florida

\section{GAMMARIDEAN AMPHIPODS AS BIOINDICATORS IN SUBTROPICAL SEAGRASS ECOSYSTEMS}

A dissertation submitted in partial fulfillment of the requirements for the degree of

DOCTOR OF PHILOSOPHY

in

BIOLOGY

by

Jennifer Lynn Sweatman

2016 
To: Dean Michael R. Heithaus

College of Arts, Sciences and Education

This dissertation, written by Jennifer Lynn Sweatman, and entitled Gammaridean Amphipods as Bioindicators in Subtropical Seagrass Ecosystems, having been approved in respect to style and intellectual content, is referred to you for judgment.

We have read this dissertation and recommend that it be approved.

Deron Burkepile

Kenneth Feeley

Craig Layman

Jennifer Rehage

James W. Fourqurean, Major Professor

Date of Defense: June 28, 2016

The dissertation of Jennifer Lynn Sweatman is approved.

Dean Michael R. Heithaus

College of Arts, Sciences and Education

Andrés G. Gil

Vice President for Research and Economic Development and Dean of the University Graduate School

Florida International University, 2016 


\section{ACKNOWLEDGMENTS}

First and foremost, I would like to thank my major advisor, Dr. James W.

Fourqurean. Jim supported me through my failures and successes as a doctoral student, and provided the encouragement I needed to get over the hurdles along the way. Dr.

Craig Layman was pivotal in shaping my dissertation from the early stages. Craig acted as an advisor while Jim was on sabbatical, and facilitated my doctoral and future research in Abaco. I would like to thank the remaining dissertation committee members Dr. Deron Burkepile, Dr. Jenn Rehage, and Dr. Ken Feeley, for their support and guidance through this process.

Seagrass Rangers past and present provided me with field, statistical, professional, and emotional support during my time at FIU. Dr. Justin Campbell, Dr. Elizabeth Lacey, Dr. Amanda Bourque, Rachel Decker, Alex Perez, Christian Lopes, Jason Howard, Glauco Puig-Santana, Pam Parker, Sonja Smith, Sara Wilson, and Claire Burgett helped in the developmental, data collection and processing, analysis, and/or presentation stages of this dissertation. Christina Currais, Rebecca Valls, and Cassandra Arevalo spent countless hours helping me process samples. Dr. Bryan Dewsbury provided guidance as I re-forged my career toward a more teaching-focused path. My officemate, Dr. Betsy Stoner, provided more emotional support than a licensed therapist, assisted with experimental design issues, and provided logistical support in Abaco. Emily Warschefsky and Zoe Pratt helped relieve stress by rock climbing, comedic relief, and co-commiseration. Mike Bush provided countless hours of discussions on a range of topics from statistics to experimental design to alternative career paths. Last, but not least, I'd like to thank my family for always answering my phone calls and being there 
for me when I needed to vent. I could not have made it through this process without the support of these generous folks, and I am forever grateful.

I am forever indebted to Sara LeCroy for her enthusiasm and willingness to share her knowledge of the amphipods of south Florida with me. I spent three weeks learning the art of amphipod identification from her at the Gulf Coast Research Lab in Ocean Springs, Mississippi. I would also like to thank Kristen Williams of Friends of the Environment in Abaco, Bahamas, for logistical support during my time there.

Finally, I would like to thank my funding sources. Support for this research was generously provided by the Christina Menendez Fellowship and the Women Diver's Hall of Fame. Travel funding to present the results of my research at conferences were provided by the College of Arts and Science and the Graduate and Professional Student Committee at FIU, the Florida Coastal Everglades Long-Term Ecological Research travel grant, and the Coastal and Estuarine Research Federation travel award. Funding throughout my time as a doctoral student was provided by the USEPA and NOAA funded Seagrass and Water Quality Monitoring Projects, the FCE-LTER program (NSF/OCE9910514), and a teaching assistantship provided by FIU. 


\section{ABSTRACT OF THE DISSERTATION}

\section{GAMMARIDEAN AMPHIPODS AS BIOINDICATORS IN SUBTROPICAL SEAGRASS ECOSYSTEMS}

by

Jennifer Lynn Sweatman

Florida International University, 2016

Miami, Florida

\section{Professor James W. Fourqurean, Major Professor}

Anthropogenic disturbances are ubiquitous in coastal marine ecosystems. As such, more intensive monitoring efforts are necessary to conserve these valuable habitats. Bioindicators, organisms that predictably respond to changes in environmental variables, may be utilized in monitoring efforts to assess ecosystem functioning. To incorporate organisms into monitoring programs as bioindicators managers need to first understand the difference between the natural phenology of the focal organisms and their responses to different forms of anthropogenic disturbance.

To determine if gammaridean amphipods could be used as indicators of changes in environmental quality in sub-tropical seagrass ecosystems, I conducted spatial and temporal surveys of amphipod communities in south Florida. Amphipod community structure varied significantly across sites and seasons. Variation in community structure was largely driven by macrophyte biomass, food availability, seasonally variable factors (epiphyte abundance, dissolved oxygen, salinity, and temperature), water-column nitrogen concentration, and factors related to freshwater input, including low Thalassia testudinum and high Halodule wrightii densities, and salinity. 
Amphipods are also susceptible to mechanical damage in seagrass habitats and could be used as indicators of ecological functioning of a region. A major source of mechanical damage in seagrass ecosystems is caused by boat propellers. I simulated propeller scars in continuous seagrass beds to investigate the effects of scarring on seagrass ecosystem functioning. Seagrasses located adjacent to propeller scars experienced a shift in the limiting resource from light to phosphorus. Amphipod community structure, however, was not impacted by scarring, but amphipod density was reduced in fragmented patches. To determine if plant-herbivore interactions were impacted by propeller scarring, we removed amphipods from half of the experimental plots and measured epiphyte biomass and community composition. Top-down control on epiphyte biomass or community composition by amphipods was not affected by fragmentation, despite reduced amphipod densities.

My dissertation research demonstrates that amphipods could be incorporated into existing management programs in sub-tropical seagrass ecosystems as environmental indicators. Reduced amphipod densities in fragmented seagrass beds suggests that amphipods could also be used as ecological indicators, but more research is needed to determine the extent of the impacts of fragmentation on higher trophic levels. 


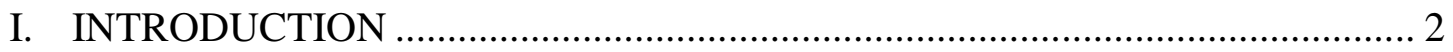

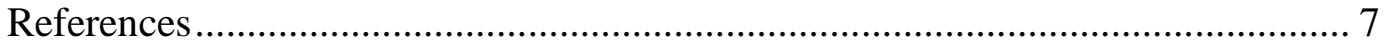

II. ENVIRONMENTAL DRIVERS OF AMPHIPOD DENSITY, DIVERSITY, AND COMMUNITY COMPOSITION ………….................................... 9

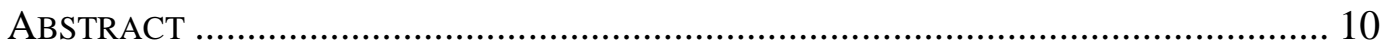

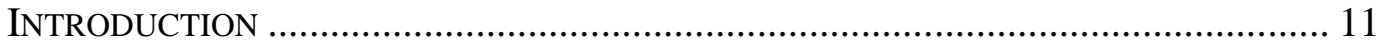

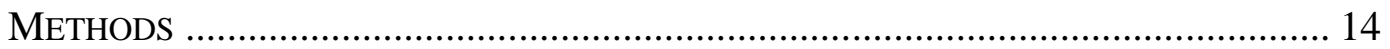

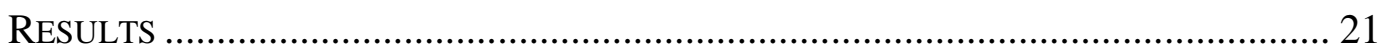

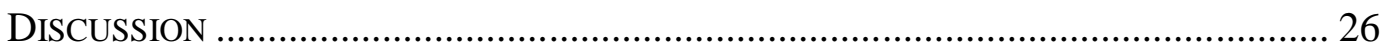

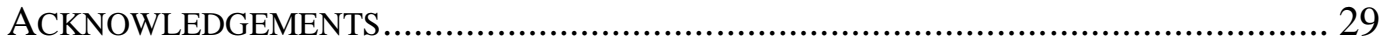

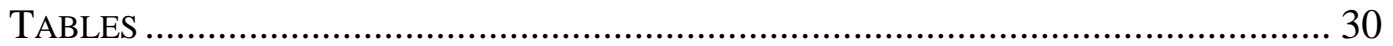

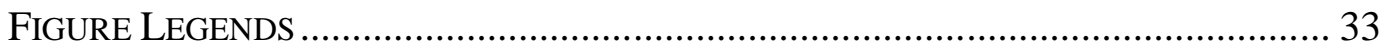

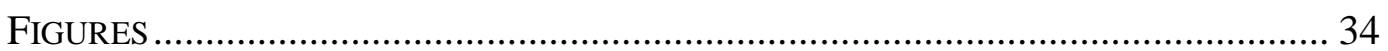

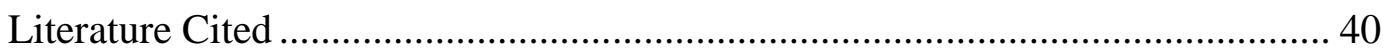

III. GAMMARIDEAN AMPHIPODS IN FLORIDA BAY AND THEIR UTILITY AS INDICATORS IN A SUBTROPICAL SEAGRASS MONITORING

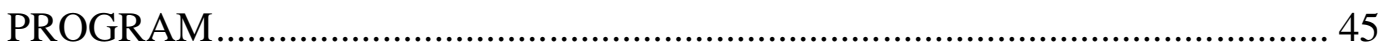

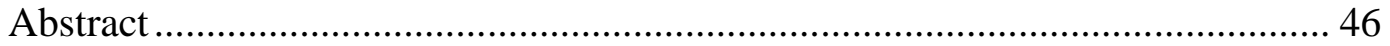

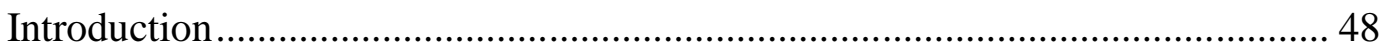

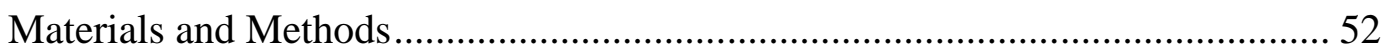

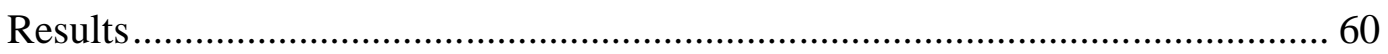

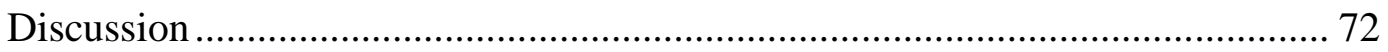

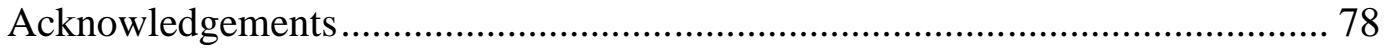

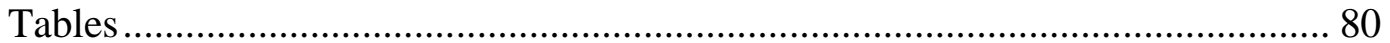

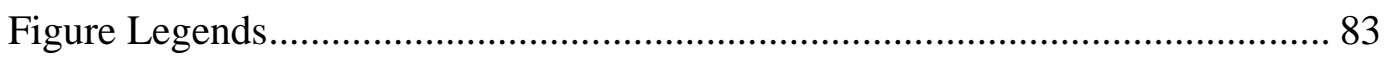

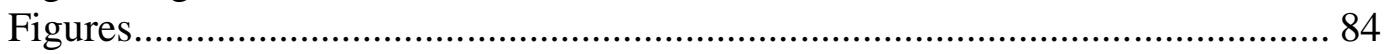

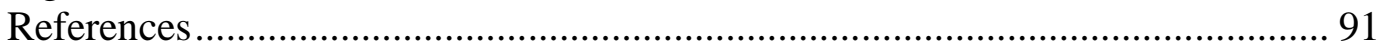

IV. HABITAT FRAGMENTATION HAS WEAK IMPACTS ON ASPECTS OF ECOSYSTEM FUNCTIONING IN A SUB-TROPICAL SEAGRASS BED ..... 99

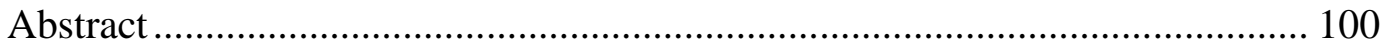

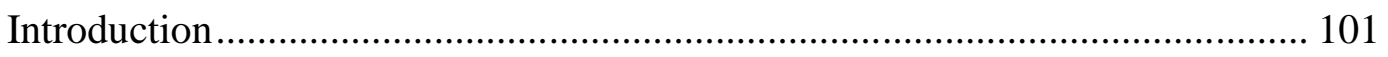

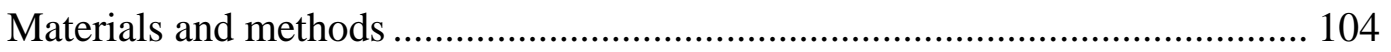

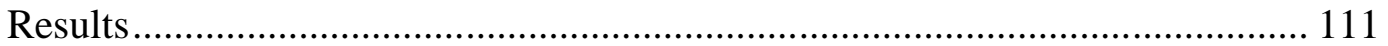

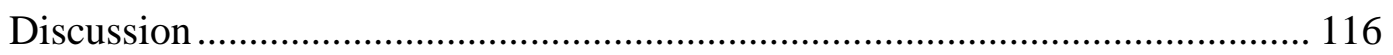

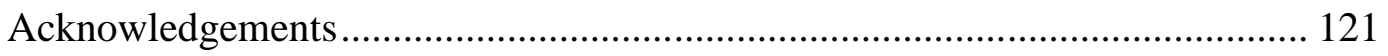

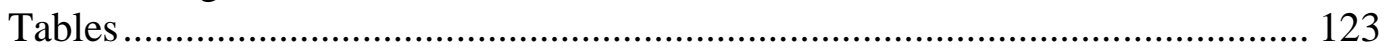




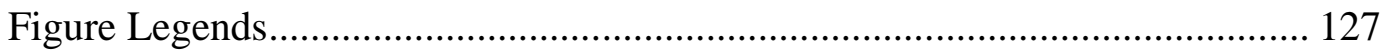

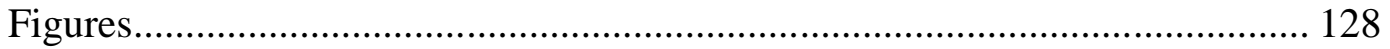

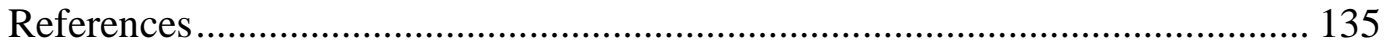

V. CONCLUSIONS AND FUTURE DIRECTIONS....................................... 143

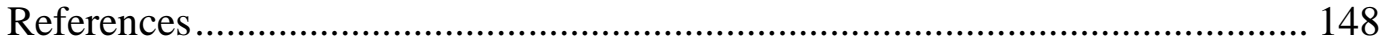

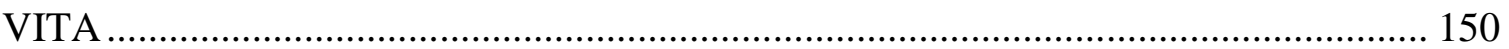




\section{LIST OF TABLES}

TABLE

PAGE

\section{CHAPTER II}

2.1 Mean \pm S.E. of amphipod density, species richness, Shannon-Wiener index, and inverse Simpson's Dominance index by site.

2.2 Results from Tukey's HSD test across sites (comparison) for standardized amphipod abundance, species richness, Shannon-Wiener diversity, and inverse Simpson's dominance index. P-values shown for significant comparisons only ...31

2.3 Standardized principle component factor loadings after varimax rotation. Variables loading strongly on each component are in bold text.

\section{CHAPTER III}

3.1 Mean \pm S.E. of amphipod density, species richness, Shannon-Wiener index, and inverse Simpson's Dominance index by site and season

3.2 Mean \pm S.E. of environmental variables and results of 1-way ANOVA for each variable across sites. Units of measure listed here in parentheses. Thalassia testudinum (BB score), Syringodium filiforme (BB score), Halodule wrightii (BB score), Halimeda spp. (BB score), Penicillus spp. (BB score), Batophora spp. (BB score), Laurencia spp. (BB score), sponge (BB score), CGT (BB score), Depth (ft), Turbidity (NTU), Temperature $\left({ }^{\circ} \mathrm{C}\right)$, Salinity (PSU), N (\%), $\mathrm{C}(\%), \mathrm{P}(\%)$, Epiphyte biomass (chl $a$ per seagrass short shoot), Dry Weight (DW in $\mathrm{g}$ of seagrass biomass collected with amphipods), Inorganic matter (weight in $\mathrm{g}$ of ashes from combusted DW), and Organic matter (weight in $\mathrm{g}$, ash-free dry weight), Nitrate+Nitrite $\left(\mathrm{NO}_{\mathbf{X}} ; \mathrm{M}\right)$, nitrate $\left(\mathrm{NO}_{3}{ }^{-} ; \mathrm{M}\right)$, nitrite $\left(\mathrm{NO}_{2} ; \mathrm{M}\right)$, ammonium $\left(\mathrm{NH}_{4}{ }^{+} ; \mathrm{M}\right)$, total nitrogen $(\mathrm{TN} ; \mathrm{M})$, dissolved inorganic nitrogen (DIN; M), total organic nitrogen (TON; M), dissolved oxygen (DO), phytoplankton chlorophyll $a(\mathrm{Chl} a ; \mathrm{g})$, total organic carbon (TOC; M), soluble reactive phosphorus (SRP; M), and total

3.3 Standardized principle component factor loadings after varimax rotation. Variables loading strongly on each component are in bold text. Units of measure listed here in parentheses. Thalassia testudinum (BB score), Syringodium filiforme (BB score), Halodule wrightii (BB score), Halimeda spp. (BB score), Penicillus spp. (BB score), Batophora spp. (BB score), Laurencia spp. (BB score), sponge (BB score), CGT (BB score), Date (as sampling month), Depth (ft), Turbidity (NTU), Temperature $\left({ }^{\circ} \mathrm{C}\right)$, Salinity (PSU), N (\%), C (\%), P (\%), Epiphyte biomass (chl $a$ per seagrass short shoot), Dry Weight (DW in $\mathrm{g}$ of seagrass biomass collected with amphipods), Inorganic matter (weight in $\mathrm{g}$ of ashes from combusted DW), and Organic matter (weight in $\mathrm{g}$, ash-free dry weight), nitrate+nitrite (NOX; M), nitrate $\left(\mathrm{NO}_{3}{ }^{-} ; \mathrm{M}\right)$, nitrite 
$\left(\mathrm{NO}_{2}{ }^{-} ; \mathrm{M}\right)$, ammonium $\left(\mathrm{NH}_{4}^{+} ; \mathrm{M}\right)$, total nitrogen $(\mathrm{TN} ; \mathrm{M})$, dissolved inorganic nitrogen (DIN; M), total organic nitrogen (TON; M), dissolved oxygen (DO), water-column chlorophyll $a(\mathrm{Chl} a ; \mathrm{g})$, total organic carbon (TOC; M), soluble reactive phosphorus (SRP; M), and total phosphorus (TP; M).

\section{CHAPTER IV}

4.1 Predicted and observed responses to habitat fragmentation in seagrass ecosystems from Abaco, Bahamas. E= Edge, I= Interior, and C= Continuous. Predictions were derived from previous studies on the effects of propeller scarring in seagrass ecosystems, and habitat fragmentation or patch dynamics of gammaridean amphipods.

4.2 Table detailing plots and initial models used to test for Fragmentation or Edge Effects. $\mathrm{CS}=$ Cherokee Sound, and JC= Jungle Creek

4.3 Average values \pm standard error for seagrass percent cover and productivity across treatments at each site. Differences between sites are significantly different for each seagrass metric. $\mathrm{Tt}=$ Thalassia testudinum; LAI=Leaf Area Index

4.4 Minimum, mean and maximum epiphyte biomass by main effect (site, habitat type, and grazer treatment) as described by the epiphyte autotrophic index ( $\mu \mathrm{g}$ Chl $a \mathrm{~g}^{-1}$ epiphyte dry mass) and leaf specific epiphyte biomass ( $\mu \mathrm{g}$ Chl $a$ leaf area $\left.^{-1}\right)$... 


\section{LIST OF FIGURES}

FIGURE

PAGE

\section{CHAPTER II}

2.1 Map of the study area. Sites are designated by black points with site identifiers (numbers or letters). Study areas include Florida Bay (TC-Trout Cove, DKDuck Key, LM-Little Madiera, BA-Bob Allen Keys, and SB-Sprigger Bank), the Florida Keys National Marine Sanctuary (215, 501, 503, 235, 237, 296, 314, and 269), and the Dry Tortugas National Park (5 and 15).

2.2 Shade plot of amphipod density by site. Each cell is shaded to correspond to the abundance of the species at that site. Darker grey cells indicate a higher density and lighter cells indicate lower density

2.3 Bar plots of a) amphipod density, b) species richness, and c) ShannonWiener diversity index by site. Error bars are standard errors. For significance see Table 2.2. Shading of boxes represents general location where black boxes are DRTO sites, light grey boxes are oceanside, and dark grey boxes are bayside and Florida Bay. Shading of bars is for illustrative purposes only

2.4 Amphipod community data by sites. Nonmetric multidimensional scaling plot illustrates similarity between sites where closer points are more similar. Shading of site symbols (circles) represents general location where black circles are DRTO sites, light grey circles are oceanside sites, and dark grey circles are bayside and Florida Bay sites. Shading is for illustrative purposes only

2.5 Maps of (a) similar amphipod communities and (b) environmental climates from cluster analyses across sites. Symbols used to identify sites within the same cluster.

2.6 Biplot of first and second principle components explaining 53\% of the variation in environmental data. Nitrogen concentration (PC1) explains $35 \%$ of the variation. Hardbottom community (octocoral density) (PC2) explains $18 \%$ of the variation.

\section{CHAPTER III}

3.1 Map of the study sites in Florida Bay. The five sites sampled were Trout Cove (TC), Duck Key (DK), Little Madiera (LM), Bob Allen Keys (BA), and Sprigger Bank (SB). 
3.2 Shade plot of amphipod density by site and season. Each cell is shaded to correspond to the density of the species at that date and time. Darker grey cells indicate a higher density and lighter cells indicate lower density

3.3 Box plots of amphipod density per $\mathrm{m}^{2}$ (a-d), species richness (e-h), Shannon-Wiener diversity index (i-1), and inverse Simpson's dominance index $(\mathrm{m}-\mathrm{p})$ by site $(\mathrm{BA}=\mathrm{Bob}$ Allen, DK=Duck Key, LM=Little Madiera, $\mathrm{SB}=$ Sprigger Bank, and $\mathrm{TC}=$ Trout Cove) and season (rows)

3.4 Nonmultidimensional scaling plot of amphipod community for each site and season. Bob Allen (BA, triangles), Duck Key (DK, asterisks), Little Madiera (LM, inverted triangles), Trout Cove (TC, x's), and Sprigger Bank (SB, circles). Months are designated by shading of symbols where the darkest symbols are for January samples and the lightest samples are for October sampling

3.5 Dendrogram of cluster analysis of the amphipod community data across sites and seasons. Dark circles at nodes indicate significantly different clusters. Non-dashed lines indicate divisions not supported at the $p<0.05$ significance level

3.6 Biplots of first and third principle components explaining $49 \%$ of the variation in environmental data. Macrophyte density (PC1) explains $37 \%$ of the variation. Freshwater input (PC3) explains $12 \%$ of the variation. Bob Allen (BA, triangles), Duck Key (DK, asterisks), Little Madiera (LM, inverted triangles), Trout Cove (TC, x's), and Sprigger Bank (SB, circles). Months are designated by shading of symbols where the darkest symbols are for January samples and the lightest samples are for October sampling

3.7 dbRDA ordination plot of the best fit model (from the DISTLM procedure) of multivariate amphipod community data as explained by the environmental components from the five Florida Bay sites in for seasons

\section{CHAPTER IV}

4.1 Map of study area. Black points indicate experimental sites 128

4.2 Schematic of experimental plots. Black shading indicated simulated propeller scar where seagrasses were removed, and grey coloring indicates where seagrasses are intact. Arrows indicate distance between ecotones $(0.25 \mathrm{~m}$ is the width of the scar; $3 \mathrm{~m}$ is the distance from the scar to the patch center) or patch centers $(10 \mathrm{~m})$. Letters indicate where samples were collected: $\mathrm{N}=$ Grazer exclusion; $\mathrm{G}=$ Grazer control; $\mathrm{C}=$ Continuous sample location; $\mathrm{I}=$ 
Interior sample location; $\mathrm{E}=$ Edge sample location; $\mathrm{P}=$ Productivity samples. Figure not drawn to scale

4.3 Nitrogen content in seagrass photosynthetic tissues within sites. Differences in nitrogen content by sampling location (panels a and c), and grazer treatments (panels $\mathrm{p}$ and $\mathrm{d}$ ). $\mathrm{G}=$ grazer control; $\mathrm{NG}=$ grazer exclusion. Significant differences indicated by letters above error bars.

4.4 Phosphorus content in seagrass photosynthetic tissues within sites.

Differences in phosphorus content by sampling location (panels a and c), and grazer treatments (panels $b$ and $d$ ). $\mathrm{G}=$ grazer control; $\mathrm{NG}=$ grazer exclusion. Significant differences indicated by letters above error bars.

4.5 Relationship between $\delta^{13} \mathrm{C}$ and \% phosphorus

4.6 Relative abundance of epiphytes by major taxonomic group at each site. $\mathrm{CS}=$ Cherokee Sound, JC= Jungle Creek

4.7 Non-metric multidimensional scaling plot illustrating community differences between sites, but not across locations within sites. Jungle Creek plots are indicated by open shapes and Cherokee Sound plots are in solid shapes. Circles are Interior plots, squares are edge plots, and triangles are continuous plots. Codes for amphipod taxa consist of four letters and '+', where Amlo is Ampithoe longimana, Amra is Ampithoe ramondi, Cyco is Cymadusa compta, Cyfi is Cymadusa filosa, Elle is Elasmopus levis, Beun is Bemlos unicornis, Grbo is Grandidierella bonnieroides, Plre is Plesiolembos rectangulatus, Prsc is Protohadzia schoenerae, Nehi is Neomegamphopus hiatus, and Shcu is Shoemakerella cubensis 


\section{PREFACE}

The following chapters will be submitted for publication and are formatted according to journal specifications:

\section{CHAPTER II}

Sweatman, J. L. and J. W. Fourqurean. Environmental drivers of amphipod density, diversity, and community composition. Bulletin of Marine Science.

\section{CHAPTER III}

Sweatman, J. L. and J. W. Fourqurean. Gammaridean amphipods in Florida Bay and their utility as indicators in a subtropical seagrass monitoring program. Ecological Indicators.

\section{CHAPTER IV}

Sweatman, J. L., C. A. Layman, and J. W. Fourqurean. Habitat fragmentation has weak impacts on aspects of ecosystem functioning in a sub-tropical seagrass bed. Marine Environmental Research. 
CHAPTER 1

INTRODUCTION 
Anthropogenic disturbances such as land use changes, increases in nutrient and contaminant pollution, harvesting of plants and animals, and introductions of nonnative species are causing reductions in biodiversity worldwide (Dirzo et al. 2014). Such reductions in biodiversity can reduce the stability of an ecosystem ultimately leading to changes in ecosystem functioning (Jackson et al. 2001; Ives \& Carpenter 2007; Hooper et al 2012; MacDougall et al. 2013). Up to $60 \%$ of the global population is situated near coasts, thereby increasing the susceptibility of coastal ecosystems to multiple, anthropogenic disturbances (Vitousek et al. 1997; Halpern et al. 2007, 2008). As such, the need for systematic monitoring programs is increasing as they are necessary to the conservation of shallow-water habitats.

Monitoring programs in marine habitats, however, are costly in terms of the time and money necessary to establish and maintain them, so it is important to design monitoring programs to collect as much information as possible while simultaneously minimizing ecological impacts and costs (Thomas 1993). Plants and animals are often used in monitoring programs as indicators of changes in an ecosystem. These organisms are broadly termed bioindicators, but can be indicative of changes in the environmental quality of a habitat (environmental indicators), the ecological functioning of a region (ecological indicators), or the biodiversity of higher taxa (biodiversity indicators)(definitions summarized in McGeoch 2007).

Effective bioindicators are abundant, have limited dispersal abilities, and respond predictably to changes in the environment (Thomas 1993). As such, plants are often focal species in environmental monitoring programs. Seagrasses, for example, are extensively monitored worldwide because their shallow, coastal distribution means they are at the 
forefront of multiple anthropogenic stressors including pollution and sedimentation from runoff, mechanical damage from boating and coastal development activities (e.g., dredging), and fisheries and over-fishing (Short et al. 2011). Plant species tend to provide information on resource availability over longer temporal scales (e.g., seagrasses provide information on the long-term resource availability of an environment, Fourqurean \& Rutten 2003), and are less sensitive to short-term changes in resource availability or to different pollutants than algal species or animals (e.g., oil and dispersants have minimal impacts on seagrasses Wilson \& Ralph 2008).

Amphipods are commonly used as environmental indicators in seagrass and other marine temperate environments where natural history research has been conducted for decades (Reish \& Barnard 1979; Conradi et al. 1997; Douglass et al. 2010). Because amphipods are sensitive to changes in their environment, they have been used as indicators of degraded water quality (de-la-Ossa-Carretero et al. 2012), oil and dispersant pollution (Gesteira \& Dauvin 2000), bioaccumulation/toxicity studies (Rainbow et al. 1989), and changes in salinity, temperature, dissolved oxygen, and turbidity (Reish \& Barnard 1979; Conradi et al. 1997). Amphipods are used less often as bioindicators in tropical environments than in temperate environments, despite the multiple, anthropogenic stressors faced by these organisms (Thomas 1993).

This dissertation investigates the use of amphipods in tropical seagrass ecosystems as environmental and ecological indicators of changes in ecosystem health and functioning. In Chapter II entitled: "Environmental drivers of amphipod density, diversity, and community composition", I collected amphipods from sites in Florida Bay, the Florida Keys National Marine Sanctuary, and Dry Tortugas National Park to identify 
amphipod community structure. The purpose of this chapter was to understand the broadscale drivers of amphipod abundance, diversity, and community composition across south Florida. Results from this chapter contribute to the necessary, but scant body of knowledge about the natural history of amphipods in this region.

Building on Chapter II, Chapter III is entitled: “Gammaridean amphipods in Florida Bay and their utility as indicators in a tropical seagrass monitoring program", and focused on understanding the temporal drivers of amphipod community structure throughout the course of a year. For organisms to be considered as bioindicators, data are needed regarding the natural variability in community structure through time. As such, this chapter contributes to the understanding of temporal variability in amphipod communities with the purpose understanding if amphipods would be good indicators of changes in environmental quality in Florida Bay.

In Chapter IV entitled: “Habitat fragmentation has weak impacts on some aspects of ecosystem functioning in a tropical seagrass bed", I simulated propeller scars in a continuous seagrass bed to understand how propeller scarring impacts seagrass ecosystem functioning. The first objective of this chapter was to understand the impacts of propeller scarring on seagrass resource dynamics by analyzing seagrass nutrient and isotope content. The second objective was to understand the impacts of propeller scarring on amphipod communities by analyzing diversity and community composition across treatments. The final objective was to understand the impact of propellers scarring on the relationship between seagrass epiphytes and grazing amphipods.

All chapters in this dissertation were focused on understanding the responses of amphipod communities to environmental variability or disturbances to evaluate the 
potential for incorporating amphipod sampling into seagrass monitoring programs in south Florida. Together Chapters II and III are the first studies to investigate the spatial and temporal drivers of amphipod communities in seagrasses of south Florida and the wider Caribbean and Gulf of Mexico bioregion. These data are important in assessing the utility of amphipods as environmental indicators, and provide baseline data on amphipod spatial and temporal distribution and the environmental drivers of amphipod distribution for managers to use in future monitoring programs. Chapter IV was the first study to investigate the effects of habitat fragmentation via propeller scarring on amphipod communities, epiphyte community composition (i.e., relative abundances of major phototrophic groups), seagrass stoichiometry, and the ecological relationship between amphipods and epiphytes. Chapter IV assessed the utility of using amphipods as ecological indicators of habitat fragmentation in seagrass ecosystems.

The chapters of this dissertation represent the first attempt at identifying the relationship between amphipod community structure and composition with multiple abiotic and biotic factors. Relationships between amphipod abundance, diversity, and community composition are documented across broad spatial and temporal scales to develop a better understanding of the natural history of these organisms. This work demonstrates that amphipods would be good environmental indicators, but more work is needed to determine if amphipods would be good ecological indicators in sub-tropical seagrass ecosystems. Results from this dissertation can be used as a baseline of natural history information upon which amphipod monitoring programs can be developed and incorporated into existing seagrass monitoring programs. 


\section{References}

Conradi, M., López-González, P.J. \& García-Gómez, C. (1997) The Amphipod Community as a Bioindicator in Algeciras Bay (Southern Iberian Peninsula) Based on a Spatio-Temporal Distribution. Marine Ecology, 18, 97-111.

de-la-Ossa-Carretero, J.A., Del-Pilar-Ruso, Y., Giménez-Casalduero, F., Sánchez-Lizaso, J.L. \& Dauvin, J.-C. (2012) Sensitivity of amphipods to sewage pollution. Estuarine, Coastal and Shelf Science, 96, 129-138.

Dirzo, R., Young, H.S., Galetti, M., Ceballos, G., Isaac, N.J.B. \& Collen, B. (2014) Defaunation in the Anthropocene. Science, 345, 401-406.

Douglass, J.G., France, K.E., Paul Richardson, J. \& Duffy, J.E. (2010) Seasonal and interannual change in a Chesapeake Bay eelgrass community: Insights into biotic and abiotic control of community structure. Limnology and Oceanography, 55, 1499-1520.

Fourqurean, J.W. \& Rutten L.M. (2003) Competing goals of spatial and temporal resolution: monitoring seagrass communities on a regional scale. Pp 257-288 in: Busch, D. E. and J.C. Trexler, eds. Monitoring ecosystems: interdisciplinary approaches for evaluating ecoregional initiatives. Island Press, Washington, D. C. $447 \mathrm{pp}$

Frankovich, T.A. \& Fourqurean, J.W. (1997) Seagrass epiphyte loads along a nutrient availability gradient, Florida Bay, USA. Marine Ecology Progress Series, 159, $37-$ 50 .

Gesteira, J.L.G. \& Dauvin, J.-C. (2000) Amphipods are Good Bioindicators of the Impact of Oil Spills on Soft-Bottom Macrobenthic Communities. Marine Pollution Bulletin, 40, 1017-1027.

Halpern, B.S., Silliman, B.R., Olden, J.D., Bruno, J.P. \& Bertness, M.D. (2007) Incorporating positive interactions in aquatic restoration and conservation. Frontiers in Ecology and the Environment, 5, 153-160.

Halpern, B.S., Walbridge, S., Selkoe, K.A., Kappel, C. V, Micheli, F., D’Agrosa, C., Bruno, J.F., Casey, K.S., Ebert, C., Fox, H.E., Fujita, R., Heinemann, D., Lenihan, H.S., Madin, E.M.P., Perry, M.T., Selig, E.R., Spalding, M., Steneck, R. \& Watson, R. (2008) A global map of human impact on marine ecosystems. Science (New York, N.Y.), 319, 948-52.

Hooper, D.U., Adair, E.C., Cardinale, B.J., Byrnes, J.E.K., Hungate, B.A., Matulich, K.L., Gonzalez, A., Duffy, J.E., Gamfeldt, L. \& O'Connor, M.I. (2012) A global synthesis reveals biodiversity loss as a major driver of ecosystem change. Nature. 
Ives, A.R. \& Carpenter, S.R. (2007) Stability and diversity of ecosystems. Science (New York, N.Y.), 317, 58-62.

Jackson, J.B. (2001) What was natural in the coastal oceans? Proceedings of the National Academy of Sciences of the United States of America, 98, 5411-8.

MacDougall, A.S., McCann, K.S., Gellner, G. \& Turkington, R. (2013) Diversity loss with persistent human disturbance increases vulnerability to ecosystem collapse. Nature, 494, 86-9.

McGeoch, M.A. (2007) The selection, testing and application of terrestrial insects as bioindicators. Biological Reviews, 73, 181-201.

Reish, D.J. \& Barnard, J.L. (1079) Amphipods (Arthropoda: Crustacea: Amphipoda). Pollution Ecology of Estuarine Invertebrates (eds C.W.J. Hart), \& S.L.H. Fuller), pp. 345-370. Academic Press, New York.

Short, F.T., Polidoro, B., Livingstone, S.R., Carpenter, K.E., Bandeira, S., Bujang, J.S., Calumpong, H.P., Carruthers, T.J.B., Coles, R.G., Dennison, W.C., Erftemeijer, P.L.A., Fortes, M.D., Freeman, A.S., Jagtap, T.G., Kamal, A.H.M., Kendrick, G.A., Judson Kenworthy, W., La Nafie, Y.A., Nasution, I.M., Orth, R.J., Prathep, A., Sanciangco, J.C., Tussenbroek, B. van, Vergara, S.G., Waycott, M. \& Zieman, J.C. (2011) Extinction risk assessment of the world's seagrass species. Biological Conservation, 144, 1961-1971.

Thomas, J.D. (1993) Biological monitoring and tropical biodiversity in marine environments: a critique with recommendations, and comments on the use of amphipods as bioindicators. Journal of Natural History, 27, 795-806.

Vitousek, P.M., Mooney, H.A., Lubchenco, J. \& Melillo, J.M. (1997) Human Domination of Earth's Ecosystems. Science, 177.

Wilson, K.G. \& Ralph, P.J. (2008) A comparison of the effects of tapis crude oil and dispersed crude oil on subtidal Zostera capricorni. International Oil Spill Conference Proceedings, 2008, 859-864. 
CHAPTER II

ENVIRONMENTAL DRIVERS OF AMPHIPOD DENSITY, DIVERSITY, AND COMMUNITY COMPOSITION 


\section{Abstract}

The use of organisms as bioindicators of changes in environmental quality is limited by the availability of natural history data on the potential indicator.

Understanding the spatial distribution of potential indicators is necessary to determine if detected changes in their distribution is a result of the natural phenology of the organism or is in response to changes in environmental variables. I studied amphipod community composition, density, diversity, and species richness in relation to environmental drivers at 15 sites in south Florida seagrass beds. Amphipod community composition and diversity were largely driven by site-specific differences in macrophyte biomass, epiphyte biomass and seasonally variable factors (dissolved oxygen and temperature), nitrogen concentration, and factors associated with hardbottom habitats (e.g., high macroalgal diversity and low seagrass density) as determined by principle components analysis. Macrophyte biomass described $37 \%$ of the variation in amphipod density among sites where sites with high macrophyte biomass and sites with low macrophyte biomass had high amphipod densities. Epiphyte abundance and seasonally variable factors explained $32 \%$ of the variation in diversity and $26 \%$ of the variation in species richness among sites. Sites with high epiphyte abundance, low temperature and low dissolved oxygen were characterized by low amphipod diversity and richness. These results suggest that amphipod community structure is variable through time in response to environmental variability (e.g., temperature and dissolved oxygen). We recommend increasing sampling effort both spatially and temporally to develop a more comprehensive understanding of the environmental drivers of amphipod community structure, and the natural phenology of gammaridean amphipods. 


\section{INTRODUCTION}

The spatial distribution of organisms is regulated by a suite of interacting biotic and abiotic variables. Understanding how populations and communities respond to specific drivers regulating spatial distribution patterns is an important pre-requisite when designing monitoring programs. Furthermore, managers need to be able to distinguish between natural and anthropogenically-induced changes in spatial patterns of potential bioindicator species to incorporate them into monitoring programs as indicators of environmental or ecological changes in an ecosystem (Noss 1990; Spellerberg 1991). As such, a baseline of natural history data needs to be available for reference.

Gammaridean amphipods are widely used in temperate monitoring programs in marine and aquatic environments as indicators of nutrient enrichment (de-la-OssaCarretero et al. 2012), oil pollution and associated dispersants (Gesteira and Dauvin 2000), and heavy metals (Rainbow \& White 1989). Amphipods are under-utilized as bioindicators in tropical ecosystems, however (Thomas 1993). An effort has been made in recent decades to understand the drivers of amphipod abundance and diversity in northern and central Florida (Young and Young 1976; Young et al. 1978; Nelson 1979, 1980; Stoner 1980a, 1980b; Nelson et al. 1982; Lewis and Stoner 1983; Lewis 1987; Schneider and Mann 1991), but little is known about their distribution and diversity in south Florida.

The distribution of gammaridean amphipod species is dependent on top-down control (i.e., fish predation) and species-specific tolerances to variability in many environmental factors. Amphipods are found in high abundances in dense, vegetated habitats (Heck and Wetstone 1977; Stoner 1980a, 1980b; Lewis and Stoner 1983; Orth et 
al. 1984; Stoner and Lewis 1985), because the structural complexity provides refuge from predation (Russo 1987). Furthermore, amphipod communities have strong interannual variability because of species-specific responses to abiotic factors, such as, salinity, temperature, dissolved oxygen, and turbidity (see Douglass et al. 2010). Sediment type can also limit the colonization of a habitat by domicolous or tube-dwelling amphipods as these species require extremely fine sediment types to construct their tubes (Barnard 1970, Bousfield 1973, Barnard 1991, Bousfield and Hoover 1997).

Florida Bay, the Florida Keys National Marine Sanctuary (FKNMS), and Dry Tortugas National Park (DRTO) are of economic importance in south Florida, generating billions of dollars in tourism and fishing revenues each year (NOAA 2007), and are currently affected by Everglades restoration efforts and anthropogenic disturbances (Sklar et al. 2002; Klein and Orlando 1994; Fourqurean and Robblee 1999; Fourqurean and Rutten 2003; Kruczynski and McManus 2002; Collado-Vides et al. 2007). As such, seagrass and water-quality monitoring was established in Florida Bay as part of the Florida Coastal Everglades Long-Term Ecological Research (FCE-LTER), the FKNMS Seagrass and Water Quality Monitoring Projects (Fourqurean and Rutten 2003), and Dry Tortugas National Park (DRTO) to monitor ecosystem responses to anthropogenic impacts in south Florida.

Incorporating both plants and primary consumers into monitoring programs can provide information of both short and long-term effects of disturbance on ecosystem health and future functioning. Different pollutants, including nutrients, oil, sediments, and heavy metals, can have very different impacts on the plant and animal populations associated with nearshore habitats (e.g., oil and dispersants have little impact on 
seagrasses but crustaceans are more sensitive to oil- and dispersant-associated pollutants than are seagrasses; Gesteira and Dauvin 2000; Wilson and Ralph 2008). The first objective of this study was to determine the differences in amphipod density, species richness, species diversity, and amphipod community composition in DRTO, Florida Bay, and the FKNMS. The second objective was to understand the spatial differences in multivariate amphipod community composition and environmental variables across sites. The final objective was to determine the environmental drivers of amphipod community composition. We surveyed gammaridean amphipod communities at 15 sites in near-shore marine and estuarine waters in south Florida that differed markedly in environmental characteristics, ranging from clear-water, backreef seagrass meadows to sites with highly variable salinity, temperature and water quality close to the mainland of Florida. We include in our analysis data collected in conjunction with three separate monitoring programs. Data collected as part of the FCE-LTER (Florida Bay sites only) and the FKNMS benthic habitat monitoring programs include data on macrophyte density and seagrass nutrient content, which is used as a metric of long-term nutrient availability at each site (Frankovich and Fourqurean 1997). The Water Quality Monitoring and Projection Project collects data on a suite of water column variables, which are more indicative of current environmental conditions. We hypothesize that site-specific macrophyte and abiotic characteristics (hereafter environmental climates) will explain the variability associated with amphipod communities among sites in Florida Bay, the FKNMS, and DRTO. 


\section{METHODS}

\section{Site Description}

Quarterly monitoring of seagrass-dominated benthic habitats began in 1996 at 30 permanent sites within the FKNMS (Fig. 2.1; see Fourqurean and Rutten 2003 for details). The project was expanded in 2012 to include an additional 10 sites located nearer to shore than the original 30 sites. Bi-monthly monitoring of 5 sites began in Florida Bay in 2000 as part of the FCE-LTER program, which was designed to monitor ecosystem responses (e.g., primary productivity, and trophic, nutrient, and landscapescale dynamics) to restoration efforts in south Florida (Childers 2006). Permanent seagrass monitoring sites ( $\mathrm{N}=17$ sites) were also established within Dry Tortugas National Park (DRTO) in 2012. To assess the spatial and environmental controls on amphipod community composition in the current study, samples were collected at 10 haphazardly selected sites from the permanent monitoring sites established in the FKNMS and DRTO in July 2013. Samples collected at the 5 FCE-LTER monitoring sites in Florida Bay were collected in July 2014.

The FKNMS, DRTO, and Florida Bay are shallow, coastal habitats that include extensive seagrass beds, coral reefs, and mangrove islands. The FKNMS covers an area of 2,900 $\mathrm{nmi}^{2}$, which includes DRTO (NOAA 2007). The dominant seagrass species in these regions are Thalassia testudinum, Syringodium filiforme, and Halodule wrightii. Macrophyte cover varies spatially (Fourqurean et al. 2001) and, as such, provides the opportunity to sample sites with varying degrees of habitat complexity (based on species present and percent cover) within relatively close proximity. Resource availability, as 
determined from seagrass tissue analyses, also varies spatially allowing for samples to be collected from a variety of nutrient regimes (Campbell and Fourqurean 2009).

\section{Macrophyte assessment and sampling}

Surveys of benthic vegetation were conducted along $50 \mathrm{~m}$ permanent transects as part of all three monitoring programs. Percent cover of benthic vegetation (seagrasses and macroalgae) and organisms (sponges and coral) was assessed using a modified BraunBlanquet technique. Along each transect, $0.25 \mathrm{~m}^{2}$ quadrats were assessed at 10 randomly selected points. A Braun-Blanquet score between 0 and 5 was assigned to each taxa present where a score of 0.1 is used when a solitary individual is covering $\leq 5 \%, 0.5$ indicates a few individuals covering $\mathbf{5 \%}, 1$ indicates numerous individuals covering $\leq$ $5 \%, 2$ indicates $5 \%-25 \%$ cover, 3 indicates $25 \%-50 \%$ cover, 4 indicates $50 \%-75 \%$ cover, and 5 indicates $75 \%-100 \%$ cover. Braun-Blanquet scores were then used to estimate density of each taxon $\left(\right.$ Density $\left._{i}\right)$ present, calculated as follows:

$$
\text { Density }_{i}=\frac{\left(\sum_{\mathrm{j}=1}^{n} S_{i j}\right)}{N_{i}} \times \frac{N_{i}}{n}
$$

where $N$ is the number of quadrats sampled at a site in which species $i$ is present, $n$ is the total number of quadrats sampled, and $S_{i j}$ is the Braun-Blanquet score for species $i$ in the $j^{\text {th }}$ quadrat (Fourqurean and Rutten 2003). Abiotic data were collected at each site, including surface and bottom temperature, surface salinity, turbidity, and light attenuation.

Short shoots from all seagrasses present were collected for nutrient analyses. Seagrass leaves were first scraped free of epiphytes using a razor blade. Epiphyte tissue 
was stored in $20 \mathrm{~mL}$ scintillation vials wrapped in foil to prevent light exposure and placed in the freezer at $-20^{\circ} \mathrm{C}$. Seagrasses were assessed for leaf morphology (leaf length and width) and dried at $60{ }^{\circ} \mathrm{C}$ to a constant weight. Dried seagrasses were weighed and homogenized for nutrient analyses. Total phosphorus content was determined using a dry-oxidation, acid hydrolysis extraction with calorimetric analysis (Fourqurean et al. 1992). Carbon and nitrogen content were determined using a CHN analyzer (Fisions NA1500). Chlorophyll $a$ content was used as a proxy for epiphyte biomass. Scraped epiphyte material was lyophilized to obtain a dry weight. Chlorophyll $a$ pigments were extracted for 24-48 hours using $90 \%$ acetone. Chlorophyll $a$ concentrations were determined using a Shimadzu RF-5301PC Spectrofluorophotometer. Total epiphyte load was estimated as leaf-specific chlorophyll $a\left(\mu \mathrm{g} \mathrm{Chl} a\right.$ leaf area $\left.{ }^{-1}\right)$.

\section{Amphipod collection}

Replicate samples were collected from each site ( $n=5-10$ replicates) using a modified Virnstein Grabber (Virnstein and Howard 1987; Douglass et al. 2008). Samples were collected adjacent to monitoring transects in plots with similar macrophyte community composition to that along the transect. The grabber samples an area of $0.4 \mathrm{~m}^{2}$ by removing aboveground seagrass biomass and minimizing sediment collection. Samples were rinsed through $400 \mathrm{~m}$ mesh filter bags and stored on ice during transport to the lab where they were stored at $-20{ }^{\circ} \mathrm{C}$ until they were processed. Macrophytes were removed and the remaining samples were rinsed through a $500 \mathrm{~m}$ sieve to remove sediment or loose epiphytic material. Prior to identification, amphipod samples were rinsed with deionized water and sorted under a dissecting microscope. Organisms were 
stored in ethanol until identification. Amphipods were identified to the species level (LeCroy 2002). Macrophytes, including detritus, were dried to a constant weight at $60{ }^{\circ} \mathrm{C}$ (approx. 5 days). Dried macrophytes were then combusted for 4 hours at $500{ }^{\circ} \mathrm{C}$ to estimate ash free dry weight (AFDW; dry weight minus ash weight). Amphipod density was calculated as the number of amphipods within a sample divided by the AFDW (in g) of macrophytes collected in the same sample.

\section{Environmental data}

Water quality samples were collected within a month of amphipod and seagrass sampling, except where stated otherwise. Methods for field sampling and sample analyses are detailed in Boyer and Jones (2002). Water quality data were collected during July 2014 as part of the FCE-LTER program at three of the five sites sampled (Duck Key (TS/Ph 9), Bob Allen Keys (TS/Ph 10), and Sprigger Bank (TS/Ph 11);

http://fcelter.fiu.edu/data/). Data for environmental variables from two of the Florida Bay sites (Trout Cove (TS/Ph 7) and Little Madeira (TS/Ph 8)) and Dry Tortugas National Park have not been collected in recent years, so average values for historical data (July 1991-July 2008 for Florida Bay, and July 1996-July 2011 for Dry Tortugas sites) were calculated during summer months and used as a proxy for present day water quality. A notable caveat to this analysis is that animals are more responsive to short-term changes in water quality than seagrasses, for example, and averaging historic water quality data may not be an adequate predictor of current community composition.

From these extensive monitoring datasets, we used the following water-quality variables: nitrate+nitrite $\left(\mathrm{NO}_{\mathbf{X}} ; \mathrm{M}\right)$, nitrate $\left(\mathrm{NO}_{3}{ }^{-} ; \mathrm{M}\right)$, nitrite $\left(\mathrm{NO}_{2}{ }^{-} ; \mathrm{M}\right)$, ammonium 
$\left(\mathrm{NH}_{4}{ }^{+} ; \mathrm{M}\right)$, total nitrogen (TN; M), dissolved inorganic nitrogen (DIN; M), total organic nitrogen (TON; M), total phosphorus (TP; M), soluble reactive phosphorus (SRP; M), total organic carbon (TOC; M), chlorophyll $a(\mathrm{CHLa} ; \mathrm{g})$ and dissolved oxygen (DO, mg L $\mathrm{L}^{-1}$ ). Data from the water quality monitoring programs were augmented with data collected during the seagrass and amphipod sampling, including water depth, turbidity, temperature, salinity, nutrient content of photosynthetic tissues (carbon, nitrogen, phosphorus), epiphyte abundance (chlorophyll $a$ per g seagrass tissue), seagrass biomass in $0.4 \mathrm{~m}^{2}$ area ( $\mathrm{g}$ dry weight, $\mathrm{g}$ organic matter, and $\mathrm{g}$ inorganic matter), and macrophyte densities (Thalassia testudinum, Syringodium filiforme, Halodule wrightii, calcareous green total density, Batophora spp., Dasycladus spp., chlorophytes (not including calcareous green algae), rhodophytes (not including Laurencia sp.), phaeophytes, and sponges).

\section{Statistical analysis}

We analyzed patterns in density, species richness, diversity, and species dominance across sites (Objective I) using 1-way analysis of variance (ANOVA). To standardize the number of individual collected at each site during each sampling season, rarefied richness was calculated:

$$
E S_{n}={ }_{i=1}^{S} \mid 1-\frac{\left(N-N_{i}\right) !(N-n) !}{\left(N-N_{i}-n\right) ! N !}
$$

where the expected number of species $E S$ from a sample of fewer individuals $n$ was calculated using the number of species $S$ with $N$ individuals of species $i$ (Clarke et al. 
2014). Shannon-Wiener $(H)$ and inverse Simpson's $(D)$ indices were used to estimated species diversity and dominance, respectively. $H$ and $D$ were calculated as follows:

$$
H=-\sum_{i=1}^{s} p_{i} \log _{b} p_{i}
$$

Where $p_{i}$ is the proportion of species $i$, and $\mathrm{S}$ is the number of species (Oksanen et al. 2015). Dependent variables were $\ln (X+1)$ transformed when necessary to meet the assumptions of normality and homoscedasticity for ANOVA.

Multivariate amphipod community differences among sites (Objective II) were examined using a 1-factor permutational ANOVA (PERMANOVA). Community data were first square root transformed to down-weight the abundance of dominant taxa (Clarke 1993). The community matrix was then standardized by the total number of species and a resemblance matrix was calculated using Bray-Curtis dissimilarity (Clarke et al. 2014). The dissimilarity among sites was plotted in a non-metric multidimensional scaling plot where sites within close proximity to each other are more similar than further sites. Significant groups, or clusters, were identified using hierarchical cluster analysis. The similarity profile procedure (SIMPROF; Clarke et al. 2014) was used to identify multivariate clusters significant to the $p<0.05$ level. Species contributing to differences among clusters were identified by the SIMPROF procedure were identified using the similarity percentage procedure (SIMPER).

Several environmental variables were highly correlated as determined by Spearman's rho rank correlation (Hmisc package in R; Harrell et al. 2016). As such, principle components analysis (PCA) was used to reduce our original environmental dataset of 33 variables to principle components (PCs). The environmental data were 
normalized by first transforming $[\log (\mathrm{X}+1)]$ them and then calculating $\mathrm{z}$-scores for each variable. A resemblance matrix was calculated using Euclidean distance. We used a varimax rotation on the components to facilitate their interpretation. Hierarchical cluster analysis and SIMPROF procedure were used to identify significant groupings of environmental variables by sites (Objective II). Environmental variables contributing to the differences between clusters were identified using SIMPER analysis.

For objective III, the environmental variables contributing to differences in amphipod community composition, density, species richness, and diversity were determined using distance-based linear models (DISTLM; Primer v.6). The DISTLM procedure is a multivariate multiple regression used to test the significance between the amphipod community matrix, amphipod density, species richness, or diversity metrics, and our environmental data represented as PC scores. A linear model using Bray-Curtis dissimilarity (for the amphipod community matrix) or Euclidean distance (for amphipod density, species richness, and diversity) resemblance matrices was fit using DISTLM. We used DISTLM to determine the best model of environmental components describing the variation in amphipod communities. We used the 'Best' model selection procedure in the DISTLM analysis, which analyzes every possible combination of environmental variables to identify the best fit model. Models were permuted 9999 times and ranked using the AICc selection criterion. The contribution of each independent variable was described by the amount of variation explained (Anderson et al. 2008). 


\section{RESULTS}

A total of 2593 amphipods were identified from 15 sites across south Florida. These amphipods represented 48 unique species from 20 families (Fig. 2.2). Amphipod density (Fig. 2.3a; Table 2.1), species richness (Fig. 2.3b), and Shannon-Wiener diversity (Fig. 2.3c) were all significantly different across sites $(\mathrm{p}<0.001$ for all metrics; see Table 2.2 for results of Tukey’s HSD). Amphipod community composition was significantly different across sites (PERMANOVA; $\mathrm{p}<0.001)$. Non-metric multidimensional scaling of amphipod communities illustrated differences across sites with a stress of 0.11 (Fig. 2.4). In general, sites located bay-side were more similar to each other (dark grey circles, Fig. 2.4) than to oceanside sites. Sites located within Florida Bay (Trout Cove, Little Madiera, Duck Key, and Bob Allen) were similar to each other. Sites with high macrophyte cover, including the western-most Florida Bay site (Sprigger Bank, 503, 501, 314, and 296) are more similar to each other than to sites with less macrophyte cover. Despite the large distance over deeper waters between DRTO and FKNMS/Florida Bay, DRTO sites (in black, Fig. 2.4) did not cluster together, away from other sites.

Site-wise cluster analysis of the amphipod community data identified three distinct clusters that were significant at the $\mathrm{p}<0.05$ level (denoted by grey squares at nodes, Fig. 2.5a). The strongest difference between clusters as indicated by low similarity (4.32\% similar), occurred between sites 5 and 215, and all other sites. Interestingly, sites 5 and 215 are the western- and eastern-most sites. The amphipod communities in these two clusters were $95.68 \%$ different, and SIMPER analysis between the clusters identified Ampithoe ramondi as the species contributing the most (40.95\%) to the differences 
between clusters. All other species in these particular clusters contributed $<10 \%$ to the difference. The second significant clustering occurred at $10.51 \%$ similarity and sites 235 , 237, 269, and Trout Cove were in one cluster, and sites 15, 296, 314, 501, 503, Bob Allen, Duck Key, Little Madiera, and Sprigger Bank were included in the second cluster. The amphipod communities between these clusters were $85.49 \%$ different with Erichthonius sp. A contributing 15.97\%, Grandidierella bonnieroides contributing $10.95 \%$, and all other species contributing $<10 \%$ to the differences between clusters. The final division occurred at $18.31 \%$ similarity between sites 296, 314, and Sprigger Bank, and sites 15, 501, 503, Bob Allen, Duck Key, and Little Madiera. The amphipod communities between these clusters were $81.69 \%$ different with Tethygeneia longleyi contributing $13.50 \%$ and all other species contributing $<10 \%$ to the differences between clusters.

Site-wise cluster analysis of the environmental data identified five distinct clusters that were significant at the $p<0.05$ level (denoted by grey squares at nodes, Fig. 2.5b). The strongest difference between clusters as indicated by the larger distance between them, occurred between sites Trout Cove and Little Madiera, and all other sites (distance $=9.85$ ). The average squared distance between clusters as determined by SIMPER analysis was 101.04 . Salinity $(6.82 \%$ contribution to dissimilarity between clusters), Halodule wrightii density (6.76\%), nitrate (6.63\%), nitrate+nitrite (6.40\%), and nitrite $(6.21 \%)$ were the variables contributing most to the dissimilarity between clusters. Both Trout Cove and Little Madiera are located near areas of significant terrestrial runoff and are characterized by low salinity and high abundance of $H$. wrightii. The second significant groupings occurred between site 237, and sites Sprigger Bank, Bob Allen, 
Duck Key, 15, 5 215, 235, 269, 501, 503, 296, and 314. The average squared distance between clusters was 78.55. The variables contributing the highest percent to the dissimilarity were non-calcifying chlorophytes (19.06\%), sponges (16.78\%), and Dasycladus spp. (10.54\%) with all other variables contributing <10\%. Site 237 is a hardbottom community characterized by a diverse macroalgal community with sparse octocorals and seagrasses throughout. The third significant clustering occurred between sites Sprigger Bank, Bob Allen, Duck Key, and sites 15, 5, 215, 235, 269, 501, 503, 296, and 314. The average squared distance between clusters was 68.75. DO contributed most to the dissimilarity between these clusters $(7.12 \%)$. The fourth significant clustering occurred between site 15 and sites 5, 215, 235, 269, 501, 503, 296, and 314. The average squared distance between clusters was 51.95. Phaeophytes (26.28\%) and epiphyte biomass $(18.36 \%)$ were the variables contributing most to the difference between clusters. The final clustering occurred between sites 5, 215, 235, and 269, and sites 501, 503, 296, and 314. The average squared distance between clusters was 41.09. Seagrass leaf carbon $(9.28 \%)$ contributed most to the dissimilarity between clusters.

Principle component analysis reduced the environmental dataset from 33 original variables to 4 principle components, which explained $75 \%$ of the variation (Fig. 2.6; Table 2.3). The first principle component explained 33\% of the variation. Variables associated with nitrogen concentration (DIN, $\mathrm{NO}_{\mathrm{X}}, \mathrm{NO}_{3}{ }^{-}, \mathrm{NH}_{4}{ }^{+}, \mathrm{NO}_{2}{ }^{-}, \mathrm{TN}$, and TON) and proximity to freshwater input (Halodule wrightii, salinity, temperature, and Thalassia testudinum) loaded heavily on the first component. Sites located near areas of terrestrial runoff (Trout Cove and Little Madiera) are characterized by seasonally variable salinity, low T. testudinum density, and high $H$. wrightii density. The second component explained 
$15 \%$ of the variation. Variables associated with macrophyte biomass (seagrass dry weight, AFDW, ashes, seagrass leaf phosphorus, and Syringodium filiforme) loaded heavily on the second component. The third component explained $14 \%$ of the variation. Variables associated with epiphyte biomass (food abundance) and seasonal factors (DO and temperature) loaded heavily on the third component. Finally, the fourth component explained $13 \%$ of the variation. Variables associated with hard bottom habitats (noncalcifying chlorophytes, sponges, and Dasycladus spp.) loaded heavily on the fourth component.

Principle component scores were used as independent variables in the DISTLM analysis to understand the relationship between amphipod multivariate community structure and univariate diversity indices, and environmental components. Amphipod samples from sites with low macrophyte biomass (Duck Key, Bob Allen, Trout Cove, and Little Madiera) separated from amphipod samples collected from sites with high macrophyte biomass (site 501, 503, 314, and 296) in the dbRDA ordination. The best model (AICc=125.22) describing the variation in multivariate community composition included the macrophyte biomass component and described $12 \%$ of the variation. Several other models were within two AICc units, and are considered statistically similar models (Burnham and Anderson 2002). These models included the hardbottom component alone (described $9 \%$ of the variation; $\mathrm{AICc}=125.68)$, the nitrogen component alone (describing $9 \%$ of the variation; $\mathrm{AICc}=125.69$ ), the epiphyte biomass component alone (describing $8 \%$ of the variation; $\mathrm{AICc}=125.93$ ), the biomass and hardbottom components together (describing $21 \%$ of the variation; $\mathrm{AICc}=126.78$ ), the biomass and nitrogen components 
together (describing $21 \%$ of the variation; AICc=126.80), and the biomass and epiphyte components together (describing 19\% of the variation; $\mathrm{AICc}=127.08$ ).

Amphipod density was positively correlated with macrophyte biomass (DISTLM marginal test $\mathrm{p}=0.02$ and explained $37 \%$ of the variation alone). The best model describing the variation in amphipod density as ranked by AICc values (AICc=97.972) included the macrophyte biomass component and described $36.9 \%$ of the variation. The second best model (AICc=99.064) included both the macrophyte biomass and hardbottom components, and described $45 \%$ of the variation. Species richness was positively correlated with the epiphyte biomass component (DISTLM marginal test $\mathrm{p}=0.055$ and explains $26 \%$ of the variation alone). The best model describing the variation in species richness included the epiphyte biomass component $(\mathrm{AICc}=-28.696)$ and described $26 \%$ of the variation. The second best model as determined by AICc values $(\mathrm{AICc}=-29.507)$ described $37 \%$ of the variation and included the epiphyte biomass and hardbottom components. The Shannon-Wiener index was positively correlated with the epiphyte biomass component (DISTLM marginal test, $\mathrm{p}=0.03$ and described $32 \%$ of the variation alone). The best model describing variation in the Shannon-Wiener index included both the epiphyte biomass and hardbottom components (AICc=-19.08), and described $49 \%$ of the variation. The second best model included only the epiphyte biomass component $(\mathrm{AICc}=-17.83)$ and described $32 \%$ of the variation. 


\section{DISCUSSION}

Research geared towards increasing understanding of the ecological role of amphipods in regulating ecosystem functioning in seagrass ecosystems has been increasing in both frequency and geographic extent. Despite the recognized ecological importance of amphipods, studies understanding the factors controlling amphipod distribution and community composition are still lacking (but see Guerra-García and García-Gómez 2001, Douglass et al. 2010, and Altermatt et al. 2014). Amphipod community composition, amphipod density, species richness, diversity, and environmental climates varied significantly across sites in our study suggesting that local environmental factors play an important role in regulating amphipod community structure. Amphipod density was highest in Florida Bay sites (Duck Key, Little Madiera, Trout Cove, and Bob Allen) and sites with high macrophyte density (501, 503, and 296). At sites where amphipod species richness and diversity were higher, epiphyte biomass was lower. Amphipod community composition was also largely driven by macrophyte biomass. Nitrogen availability and characteristics of hardbottom habitats are not significantly correlated with community composition, density, or diversity; however, they are important in describing some of the variation in our models. This study suggests that amphipod community structure could be used as bioindicators of changing environmental conditions in south Florida seagrass ecosystems.

Amphipod abundance is higher and denser in more complex seagrass habitats (Stoner 1980a, 1980b), perhaps as a mechanism for predator avoidance (Russo 1987; Young et al. 1976; Young and Young 1978; Nelson et al. 1982). With the exception of 
the Florida Bay sites in our study, amphipod density was generally higher in sites with high macrophyte density. Sites 501, 503, and 296, for example, had higher densities of both macrophytes and amphipods. Conversely, sites 5, 215, and 235 had lower macrophyte densities and lower amphipod densities. Sites in eastern Florida Bay (Duck Key, Bob Allen Key, Trout Cove, and Little Madiera) were an exception in that amphipods were found to be very abundant while macrophyte density was relatively low. Duck Key had the highest amphipod density of all sites sampled, but seagrass and macroalgae densities were very low.

Species richness and amphipod diversity were higher in sites with lower epiphyte abundances. Amphipods are important grazers in seagrass ecosystems and have been attributed to reducing the overall biomass of epiphytes attached to seagrasses, even under eutrophic conditions where epiphytes can be over-abundant (Neckles et al. 1993, Heck et al. 2000, Hughes et al. 2004; McSkimming et al. 2015). Furthermore, amphipods have species-specific grazing preferences (Duffy and Harvilicz 2001). More diverse grazer communities reduce the relative abundance of different species within the epiphyte community providing more even regulation of overall epiphyte biomass (Duffy et al. 2001). As such, the more species-rich, diverse amphipod communities in our study could be responsible for the reduced epiphyte biomass. Changes in factors regulating amphipod richness and diversity could have impacts on epiphyte biomass. For example, in overfished seagrass ecosystems, increased epiphyte biomass is attributed to a changes in top down control (Heck et al. 2000). The removal of large piscivores relieved predation pressure on smaller fish species, e.g., pinfish (Lagodon rhomboides), which prey on amphipods. The overabundance of amphipod predators caused a reduction in amphipods, 
thereby resulting in an increase in epiphyte biomass (Heck et al. 2000, Heck and Valentine 2006, Heck and Valentine 2007).

Amphipod community composition, density, diversity, and richness were not significantly related to the nitrogen or hard bottom components; however, both of these factors were important in describing some of the variation in the best fit models for community composition and amphipod density, respectively. Nitrogen is not generally the limiting nutrient in south Florida marine ecosystems (Fourqurean et al. 1992, Fourqurean and Zieman 2002), so assimilation of excess nitrogen by epiphytes would be stored in a process called luxury consumption (Tilman and Pacala, 1993). Because phosphorus is limiting in south Florida and is often unavailable to macrophytes and epiphytes (Fourqurean et al. 1992), the excess nitrogen is stored in plant and algal tissues and used when phosphorus becomes available. Amphipods and other grazers selectively graze on nitrogen-rich food sources, which can increase their overall fitness (Jiménez et al. 1996; Cruz-Rivera and Hay 2000; Duarte et al. 2010; Baggett et al. 2012). Sites with higher nitrogen availability could facilitate the assembly of different communities than sites with lower nitrogen availability. Similarly, the added complexity of multiple algal species associated with the hardbottom component could create more refuge from predators, thereby allowing for the colonization of higher densities of amphipods. For amphipods to be incorporated into monitoring programs, a clear understanding of their spatial distribution is needed. Where amphipods are currently used as bioindicators, decades of research on amphipod natural history have been conducted (Thomas 1993). We conclude from this study that amphipods could be good indicators of changes in environmental conditions of water quality in south Florida, but more data are 
needed. Because factors that vary with seasons are strong drivers of amphipod communities, we need temporal replication to understand the natural variation in amphipod community structure. As such, we recommend increased sampling effort of amphipods both spatially and temporally to increase our understanding of the natural history of gammaridean amphipods in this region.

\section{ACKNOWLEDGEMENTS}

This work was supported by the FCE-LTER program (NSF/OCE-9910514), the FKNMS water quality protection program Seagrass and Water Quality Monitoring Projects funded by NOAA (contract no. NA06NOS4780105) and the USEPA (Assistance Agreement X797468102). Special thanks the Seagrass Ecosystem Research Lab Rangers J Howard, A Perez, C Lopes, and C Burgett for helping preserve samples after long field days. J. L. S. is especially indebted to S LeCroy for her patience, enthusiasm, and time spent teaching amphipod identification. Fairchild Tropical Botanic Gardens and Dr. B Jestrow loaned J. L. S. space and microscope time in the imaging lab. This is contribution number X of the Marine Education and Research Center of the Institute for Water and the Environment at Florida International University. 


\section{TABLES}

Table 2.1. Mean \pm S.E. of amphipod density, species richness, Shannon-Wiener index, and inverse Simpson's Dominance index by site.

\begin{tabular}{lccc}
\hline Site & $\begin{array}{c}\text { Amphipod } \\
\text { Density }\end{array}$ & $\begin{array}{c}\text { Rarefied } \\
\text { Richness }\end{array}$ & $\begin{array}{c}\text { Shannon } \\
\text { Wiener }\end{array}$ \\
\hline 5 & $1.73 \pm 1.01$ & $0.33 \pm 0.17$ & $0.00 \pm 0.00$ \\
15 & $13.26 \pm 3.98$ & $1.70 \pm 0.40$ & $0.48 \pm 0.16$ \\
215 & $0.45 \pm 0.28$ & $0.50 \pm 0.34$ & $0.12 \pm 0.12$ \\
235 & $7.35 \pm 3.46$ & $1.20 \pm 0.29$ & $0.23 \pm 0.12$ \\
237 & $1.57 \pm 1.06$ & $0.50 \pm 0.22$ & $0.00 \pm 0.00$ \\
269 & $13.21 \pm 6.07$ & $1.30 \pm 0.45$ & $0.31 \pm 0.14$ \\
296 & $11.99 \pm 1.57$ & $4.19 \pm 0.32$ & $1.09 \pm 0.06$ \\
314 & $5.40 \pm 0.59$ & $7.78 \pm 0.76$ & $1.66 \pm 0.12$ \\
501 & $24.54 \pm 4.48$ & $6.49 \pm 0.58$ & $1.27 \pm 0.09$ \\
503 & $14.24 \pm 4.22$ & $4.56 \pm 0.47$ & $1.15 \pm 0.09$ \\
BA & $22.14 \pm 8.61$ & $3.60 \pm 1.12$ & $0.99 \pm 0.27$ \\
DK & $112.65 \pm 20.42$ & $8.54 \pm 0.63$ & $1.68 \pm 0.11$ \\
LM & $52.86 \pm 11.26$ & $3.60 \pm 0.24$ & $1.09 \pm 0.05$ \\
SB & $3.66 \pm 0.69$ & $4.40 \pm 0.98$ & $1.20 \pm 0.28$ \\
TC & $28.41 \pm 7.41$ & $2.20 \pm 0.20$ & $0.41 \pm 0.04$ \\
\hline
\end{tabular}




\begin{tabular}{|c|c|c|c|}
\hline Comparison & $\begin{array}{c}\text { Amphipod } \\
\text { Density }\end{array}$ & $\begin{array}{c}\text { Shannon } \\
\text { Wiener }\end{array}$ & $\begin{array}{r}\text { Rarefied } \\
\text { Richness } \\
\end{array}$ \\
\hline $215-15$ & 0.017 & & \\
\hline $296-15$ & & 0.015 & 0.003 \\
\hline $296-215$ & $<0.001$ & $<0.001$ & $<0.001$ \\
\hline $296-235$ & & $<0.001$ & $<0.001$ \\
\hline $296-237$ & 0.008 & $<0.001$ & $<0.001$ \\
\hline $296-269$ & & $<0.001$ & $<0.001$ \\
\hline $314-15$ & & $<0.001$ & $<0.001$ \\
\hline $314-215$ & & $<0.001$ & $<0.001$ \\
\hline $314-235$ & & $<0.001$ & $<0.001$ \\
\hline $314-237$ & & $<0.001$ & $<0.001$ \\
\hline $314-269$ & & $<0.001$ & $<0.001$ \\
\hline $314-296$ & & 0.047 & \\
\hline $501-15$ & & $<0.001$ & $<0.001$ \\
\hline $501-215$ & $<0.001$ & $<0.001$ & $<0.001$ \\
\hline $501-235$ & 0.006 & $<0.001$ & $<0.001$ \\
\hline $501-237$ & $<0.001$ & $<0.001$ & $<0.001$ \\
\hline $501-269$ & 0.017 & $<0.001$ & $<0.001$ \\
\hline $501-5$ & $<0.001$ & $<0.001$ & $<0.001$ \\
\hline $503-15$ & & 0.006 & 0.002 \\
\hline $503-215$ & $<0.001$ & $<0.001$ & $<0.001$ \\
\hline $503-235$ & & $<0.001$ & $<0.001$ \\
\hline $503-237$ & 0.010 & $<0.001$ & $<0.001$ \\
\hline $503-269$ & & $<0.001$ & $<0.001$ \\
\hline $503-5$ & 0.001 & $<0.001$ & $<0.001$ \\
\hline $.5-15$ & 0.032 & & 0.037 \\
\hline $5-296$ & $<0.001$ & $<0.001$ & $<0.001$ \\
\hline $5-314$ & & $<0.001$ & $<0.001$ \\
\hline BA-215 & $<0.001$ & 0.007 & $<0.001$ \\
\hline BA-235 & 0.005 & 0.012 & \\
\hline BA-237 & & $<0.001$ & 0.001 \\
\hline BA-269 & & 0.044 & 0.032 \\
\hline BA-5 & 0.001 & $<0.001$ & $<0.001$ \\
\hline DK-15 & $<0.001$ & $<0.001$ & $<0.001$ \\
\hline DK-215 & $<0.001$ & $<0.001$ & $<0.001$ \\
\hline DK-235 & $<0.001$ & $<0.001$ & $<0.001$ \\
\hline DK-237 & $<0.001$ & $<0.001$ & $<0.001$ \\
\hline DK-269 & $<0.001$ & $<0.001$ & $<0.001$ \\
\hline DK-296 & 0.003 & & \\
\hline DK-314 & $<0.001$ & & \\
\hline DK-5 & $<0.001$ & $<0.001$ & $<0.001$ \\
\hline DK-503 & 0.004 & & \\
\hline LM-15 & 0.025 & & \\
\hline LM-215 & $<0.001$ & 0.001 & $<0.001$ \\
\hline LM-235 & $<0.001$ & 0.002 & 0.018 \\
\hline LM-237 & $<0.001$ & $<0.001$ & $<0.001$ \\
\hline LM-269 & $<0.001$ & 0.009 & 0.009 \\
\hline LM-314 & 0.006 & & \\
\hline LM-5 & $<0.001$ & $<0.001$ & $<0.001$ \\
\hline SB-15 & & 0.023 & \\
\hline SB-215 & & $<0.001$ & $<0.001$ \\
\hline SB-235 & & $<0.001$ & 0.005 \\
\hline SB-237 & & $<0.001$ & $<0.001$ \\
\hline SB-269 & & 0.001 & 0.002 \\
\hline SB-5 & & $<0.001$ & $<0.001$ \\
\hline SB-DK & $<0.001$ & & \\
\hline SB-LM & 0.004 & & \\
\hline \multicolumn{4}{|l|}{ TC-15 } \\
\hline TC-215 & $<0.001$ & & 0.032 \\
\hline \multicolumn{4}{|l|}{ TC-235 } \\
\hline TC-237 & 0.001 & & \\
\hline TC-296 & & 0.043 & \\
\hline TC-314 & & $<0.001$ & 0.001 \\
\hline TC-5 & $<0.001$ & & 0.004 \\
\hline TC-501 & & 0.002 & 0.014 \\
\hline TC-503 & & 0.022 & \\
\hline TC-DK & & $<0.001$ & 0.002 \\
\hline TC-SB & & 0.040 & \\
\hline
\end{tabular}

Table 2.2. Results from Tukey's HSD test across sites (comparison) for standardized amphipod abundance, species richness, Shannon-Wiener diversity, and inverse Simpson's dominance index. P-values shown for significant comparisons only. 
Table 2.3. Standardized principle component factor loadings after varimax rotation. Variables loading strongly on each component are in bold text.

\begin{tabular}{|c|c|c|c|c|}
\hline & $\begin{array}{c}\text { PC1: } \\
\text { Nitrogen } \\
\text { Availability }\end{array}$ & $\begin{array}{c}\text { PC2: } \\
\text { Macrophyte } \\
\text { Biomass }\end{array}$ & $\begin{array}{c}\text { PC3: Food \& } \\
\text { Seasonal } \\
\text { Factors }\end{array}$ & $\begin{array}{c}\text { PC4: } \\
\text { Hardbottom } \\
\text { Habitat }\end{array}$ \\
\hline Variation explained (\%) & 33 & 15 & 14 & 13 \\
\hline Thalassia testudinum & -0.54 & 0.18 & 0.08 & -0.07 \\
\hline Syringodium filiforme & -0.31 & 0.66 & -0.18 & -0.04 \\
\hline Halodule wrightii & 0.90 & -0.24 & -0.22 & -0.17 \\
\hline Batophora spp. & -0.20 & -0.46 & 0.15 & 0.32 \\
\hline Dasycladus spp. & -0.03 & -0.11 & 0.28 & 0.82 \\
\hline Chlorophytes & 0.00 & -0.07 & 0.06 & 0.94 \\
\hline Rhodophytes & -0.27 & -0.52 & -0.08 & 0.25 \\
\hline Phaeophytes & -0.12 & 0.09 & 0.62 & 0.04 \\
\hline CGT & -0.56 & 0.04 & -0.16 & 0.55 \\
\hline Sponges & -0.14 & -0.04 & -0.15 & 0.90 \\
\hline Depth & -0.40 & 0.06 & 0.75 & 0.24 \\
\hline Salinity & -0.86 & 0.16 & 0.17 & 0.05 \\
\hline Temperature & 0.21 & -0.25 & -0.56 & -0.72 \\
\hline Turbidity & 0.22 & -0.16 & 0.11 & 0.33 \\
\hline Seagrass leaf carbon & -0.01 & -0.51 & 0.60 & -0.11 \\
\hline Seagrass leaf nitrogen & 0.40 & -0.08 & -0.01 & -0.66 \\
\hline Seagrass leaf phosphorus & -0.13 & 0.83 & 0.13 & 0.00 \\
\hline Epiphyte biomass & -0.10 & 0.12 & 0.82 & 0.07 \\
\hline Seagrass dry weight & 0.07 & 0.92 & 0.05 & 0.03 \\
\hline Inorganic matter & 0.09 & 0.90 & 0.08 & 0.02 \\
\hline Organic matter & 0.07 & 0.92 & 0.02 & 0.01 \\
\hline $\mathrm{NO}$ & 0.94 & 0.00 & -0.21 & -0.13 \\
\hline $\mathrm{NO}_{3}^{-}$ & 0.94 & -0.06 & -0.21 & -0.11 \\
\hline $\mathrm{NO}_{2}^{-}$ & 0.92 & 0.07 & -0.22 & -0.20 \\
\hline $\mathrm{NH}_{4}^{+}$ & 0.94 & 0.02 & -0.21 & -0.20 \\
\hline Total nitrogen & 0.86 & 0.31 & 0.31 & 0.05 \\
\hline Dissolved inorganic nitrogen & 0.95 & 0.06 & -0.19 & -0.18 \\
\hline Total organic nitrogen & 0.83 & 0.32 & 0.35 & 0.07 \\
\hline Total phosphorus & 0.84 & 0.27 & 0.36 & -0.10 \\
\hline Soluble reactive phosphorus & 0.80 & 0.03 & 0.11 & -0.08 \\
\hline Phytoplankton chl a & -0.04 & 0.27 & -0.81 & -0.16 \\
\hline Total organic carbon & 0.86 & 0.34 & 0.31 & 0.00 \\
\hline Dissolved oxygen & -0.43 & -0.11 & -0.73 & 0.07 \\
\hline
\end{tabular}




\section{Figure LEGENDS}

Figure 2.1. Map of the study area. Sites are designated by black points with site identifiers (numbers or letters). Study areas include Florida Bay (TC-Trout Cove, DKDuck Key, LM-Little Madiera, BA-Bob Allen Keys, and SB-Sprigger Bank), the Florida Keys National Marine Sanctuary (215, 501, 503, 235, 237, 296, 314, and 269), and the Dry Tortugas National Park (5 and 15).

Figure 2.2. Shade plot of amphipod density by site. Each cell is shaded to correspond to the abundance of the species at that site. Darker grey cells indicate a higher density and lighter cells indicate lower density.

Figure 2.3. Bar plots of a) amphipod density, b) species richness, and c) Shannon-Wiener diversity index by site. Error bars are standard errors. For significance see Table 2.2. Shading of boxes represents general location where black boxes are DRTO sites, light grey boxes are oceanside, and dark grey boxes are bayside and Florida Bay. Shading of bars is for illustrative purposes only.

Figure 2.4. Amphipod community data by sites. Nonmetric multidimensional scaling plot illustrates similarity between sites where closer points are more similar. Shading of site symbols (circles) represents general location where black circles are DRTO sites, light grey circles are oceanside sites, and dark grey circles are bayside and Florida Bay sites. Shading is for illustrative purposes only.

Figure 2.5. Maps of (a) similar amphipod communities and (b) environmental climates from cluster analyses across sites. Symbols used to identify sites within the same cluster.

Figure 2.6. Biplot of first and second principle components explaining 53\% of the variation in environmental data. Nitrogen concentration (PC1) explains $35 \%$ of the variation. Hardbottom community (octocoral density) (PC2) explains $18 \%$ of the variation. 


\section{FIGURES}

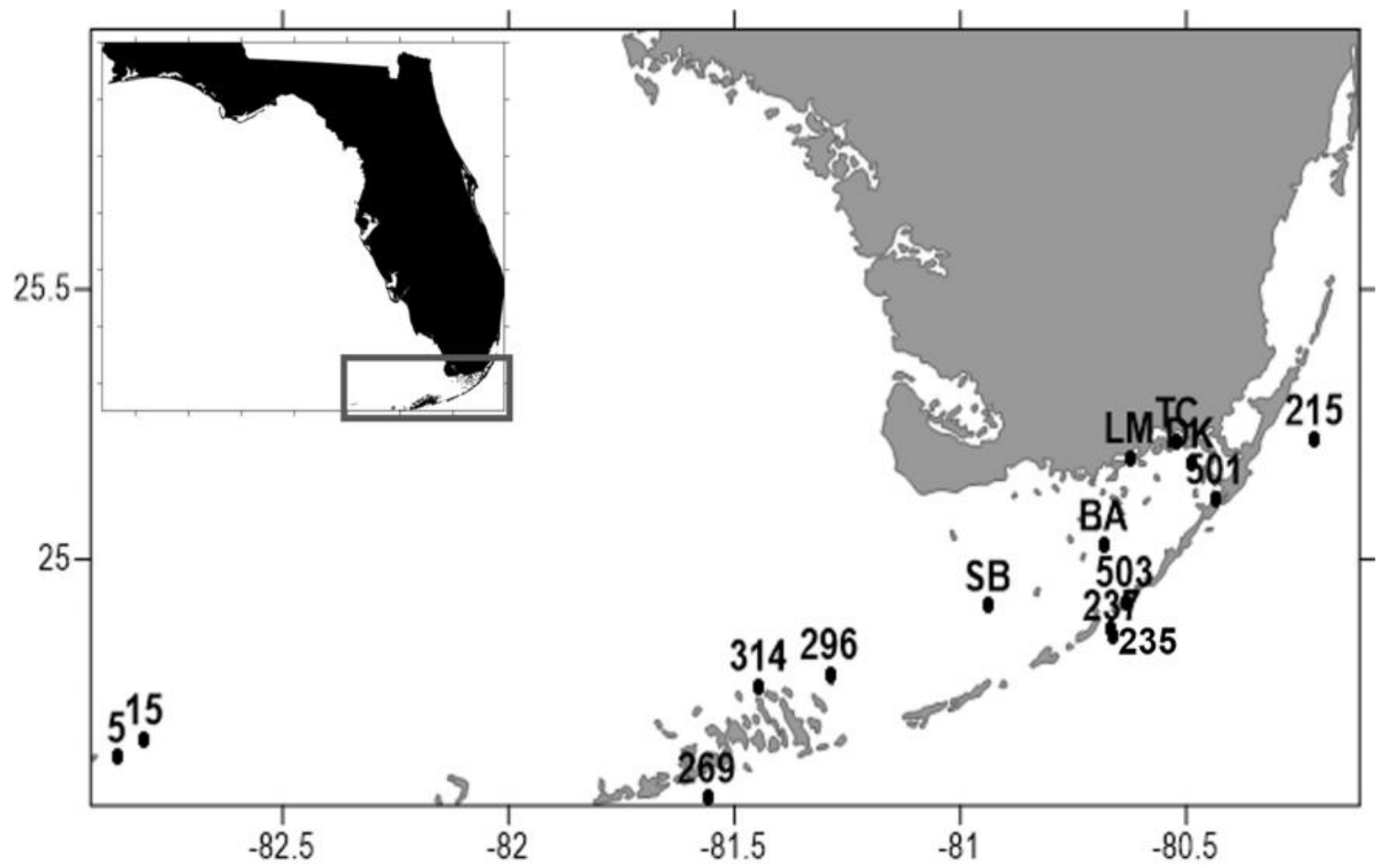

Figure 2.1. Map of the study area. Sites are designated by black points with site identifiers (numbers or letters). Study areas include Florida Bay (TC-Trout Cove, DKDuck Key, LM-Little Madiera, BA-Bob Allen Keys, and SB-Sprigger Bank), the Florida Keys National Marine Sanctuary (215, 501, 503, 235, 237, 296, 314, and 269), and the Dry Tortugas National Park (5 and 15). 
Ampelisca abdita

Ampithoe longimana

Ampithoe ramondi

Ampithoe sp. A

Ampithoe sp.

Ampelisca vadorum

Apolochus sp. A

Batea campi

Batea carinata

Batea catherinensis

Batea cuspidata

Batea sp.

Bemlos cf. longicornis

Bemlos kunkelae

Bemlos unicornis

Chevalia mexicana

Cerapus cudjoe

Cerodocus shoemakeri

Colomastix tridentata

Cymadusa compta

Dulichiella appendiculata

Dulichiella sp. A

Elasmopus levis

Erichthonius brasiliensis

Erichthonius sp. A

Eusiroides sp. A

Grandidierella bonnieroides

Hornelia tequestae

Hourstonius laguna

Latigammaropsis atlantica

Lembos unifasciatus

Leucothoe ashleyae

Leucothoe sp. B

Leucothoe sp. D

Listrella kensleyi

Lysianopsis alba

Monocorophium sp. A

Nasageneia bacescui

Neomegamphopus hiatus

Neomegamphopus kalanii

Paraphinotus seclusus

Photis sp. C

Plesiolembos rectangulatus

Podocerus kleidus

Shoemakerella cubensis

Stenothoe minuta

Tethygeneia longleyi

Varohias sp. A

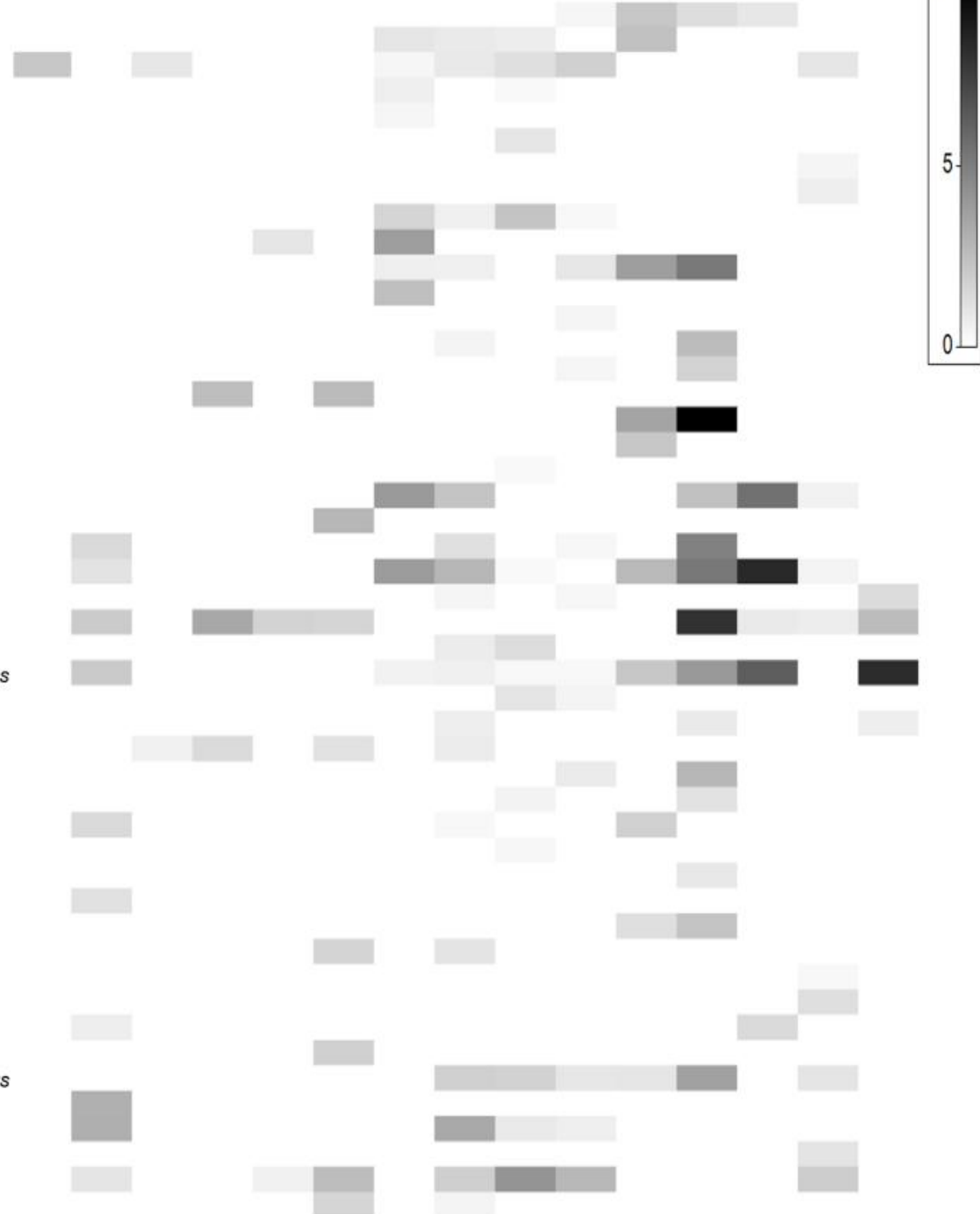

Figure 2.2. Shade plot of amphipod density by site. Each cell is shaded to correspond to the abundance of the species at that site. Darker grey cells indicate a higher density and lighter cells indicate lower density. 

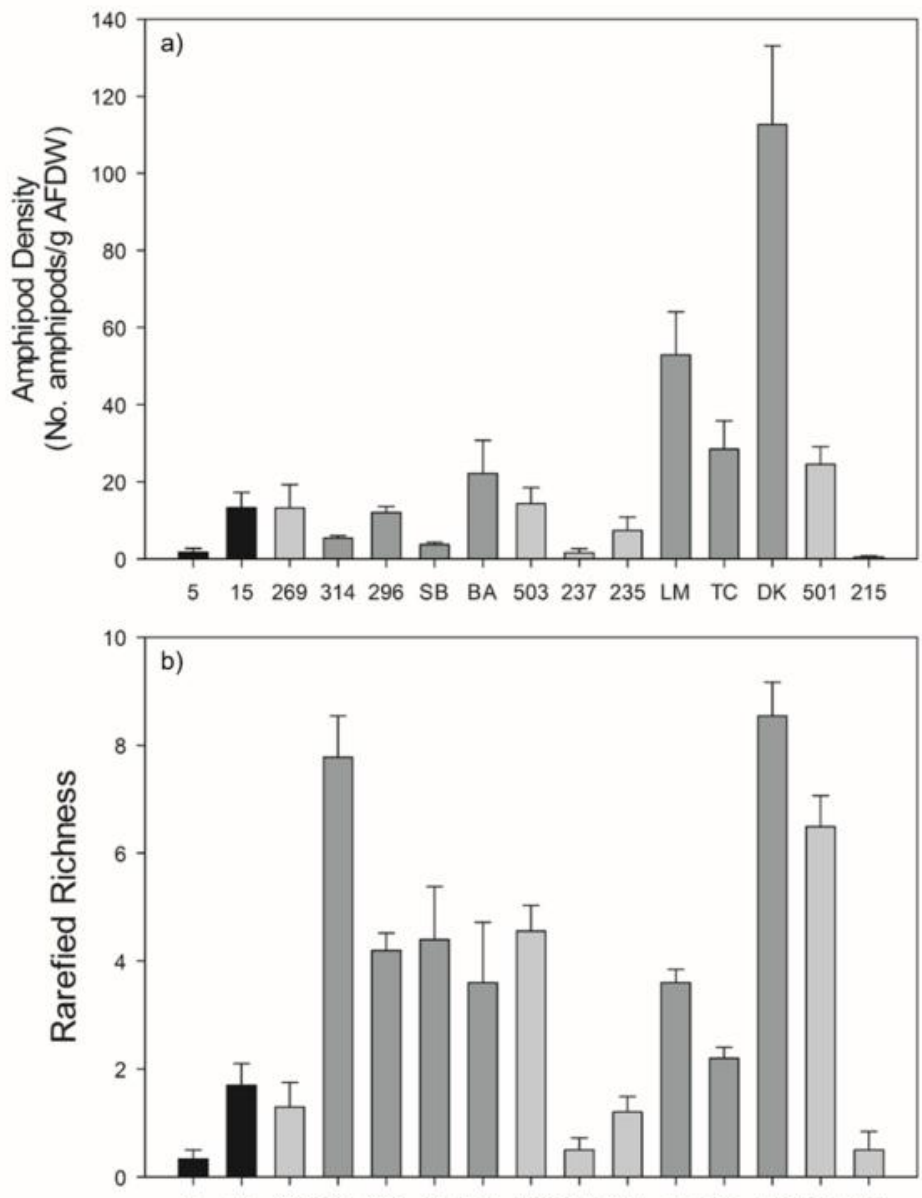

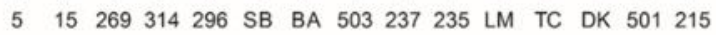

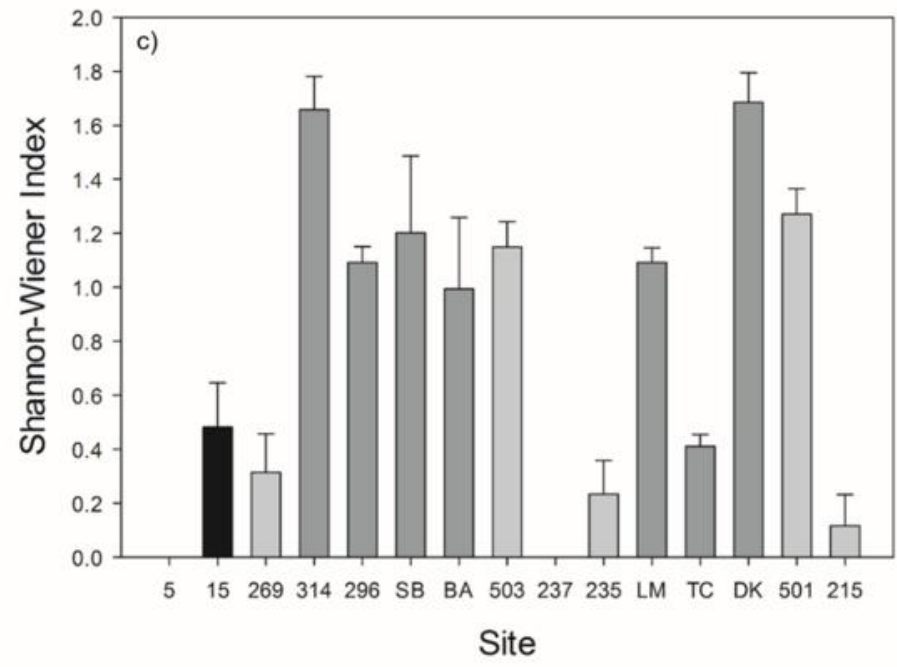

Figure 2.3. Bar plots of a) amphipod density, b) species richness, and c) Shannon-Wiener diversity index by site. Error bars are standard errors. For significance see Table 2.2. Shading of boxes represents general location where black boxes are DRTO sites, light grey boxes are oceanside, and dark grey boxes are bayside and Florida Bay. Shading of bars is for illustrative purposes only. 


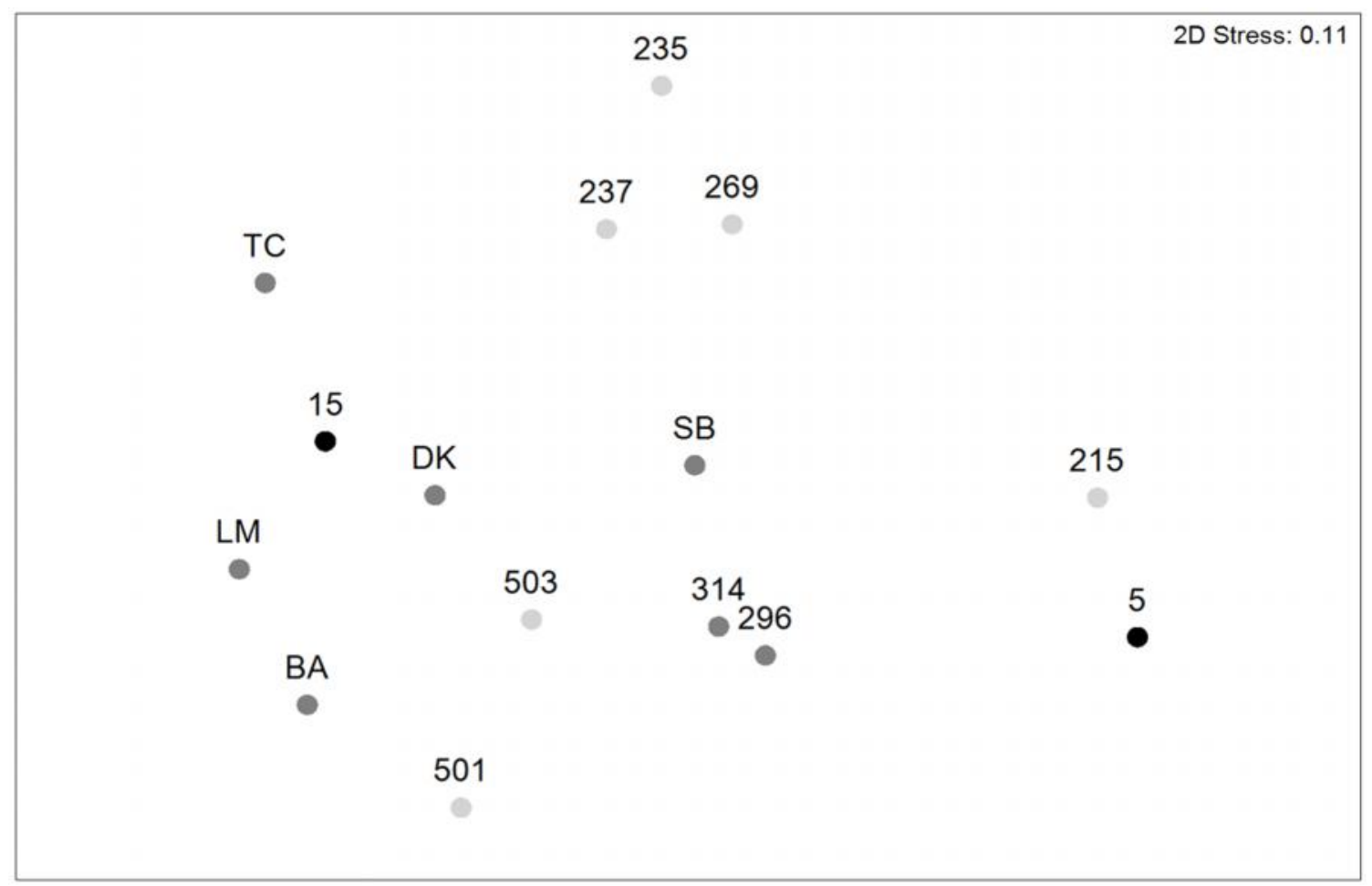

Figure 2.4. Amphipod community data by sites. Nonmetric multidimensional scaling plot illustrates similarity between sites where closer points are more similar. Shading of site symbols (circles) represents general location where black circles are DRTO sites, light grey circles are oceanside sites, and dark grey circles are bayside and Florida Bay sites. Shading is for illustrative purposes only. 

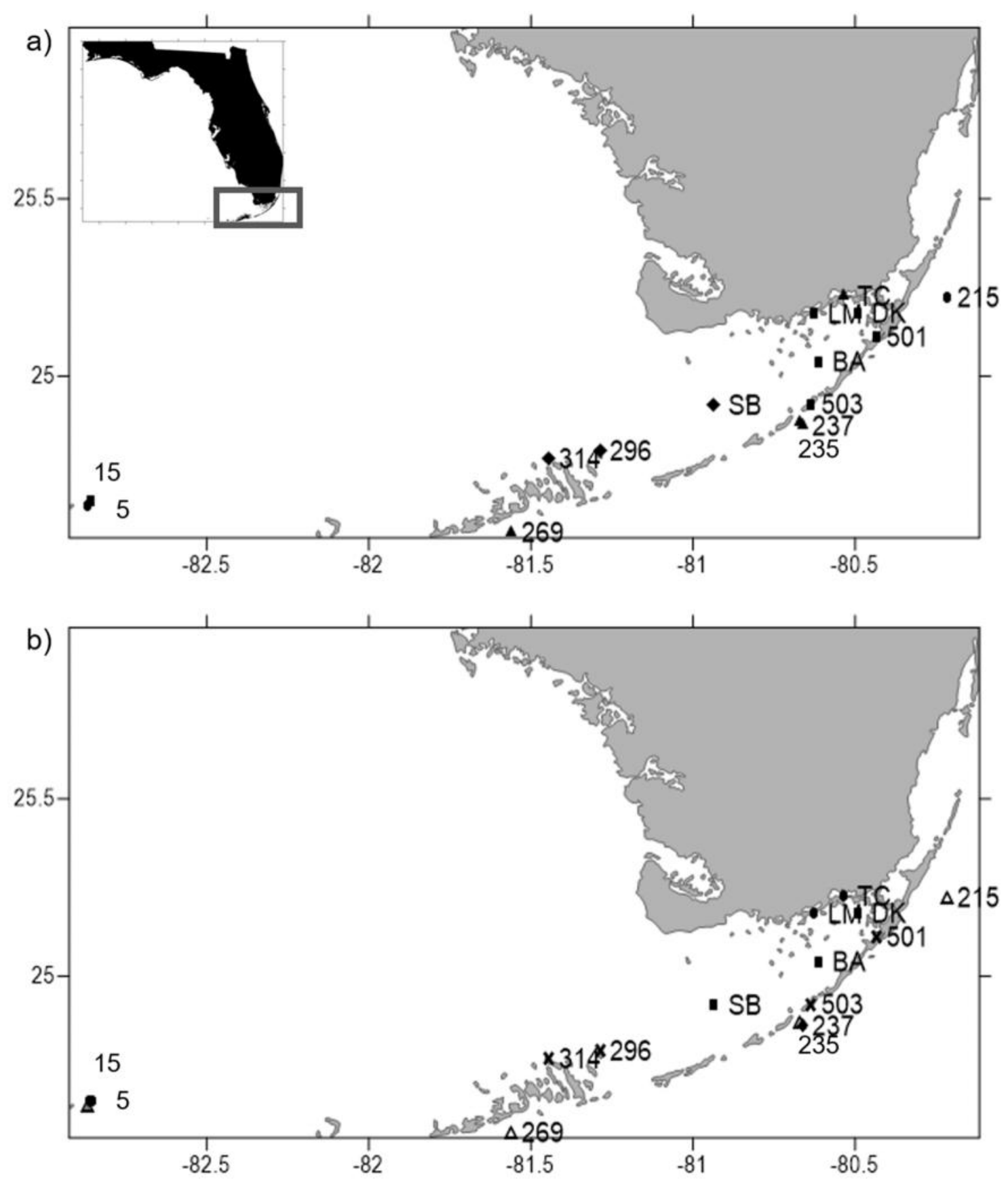

Figure 2.5. Maps of (a) similar amphipod communities and (b) environmental climates from cluster analyses across sites. Symbols used to identify sites within the same cluster. 


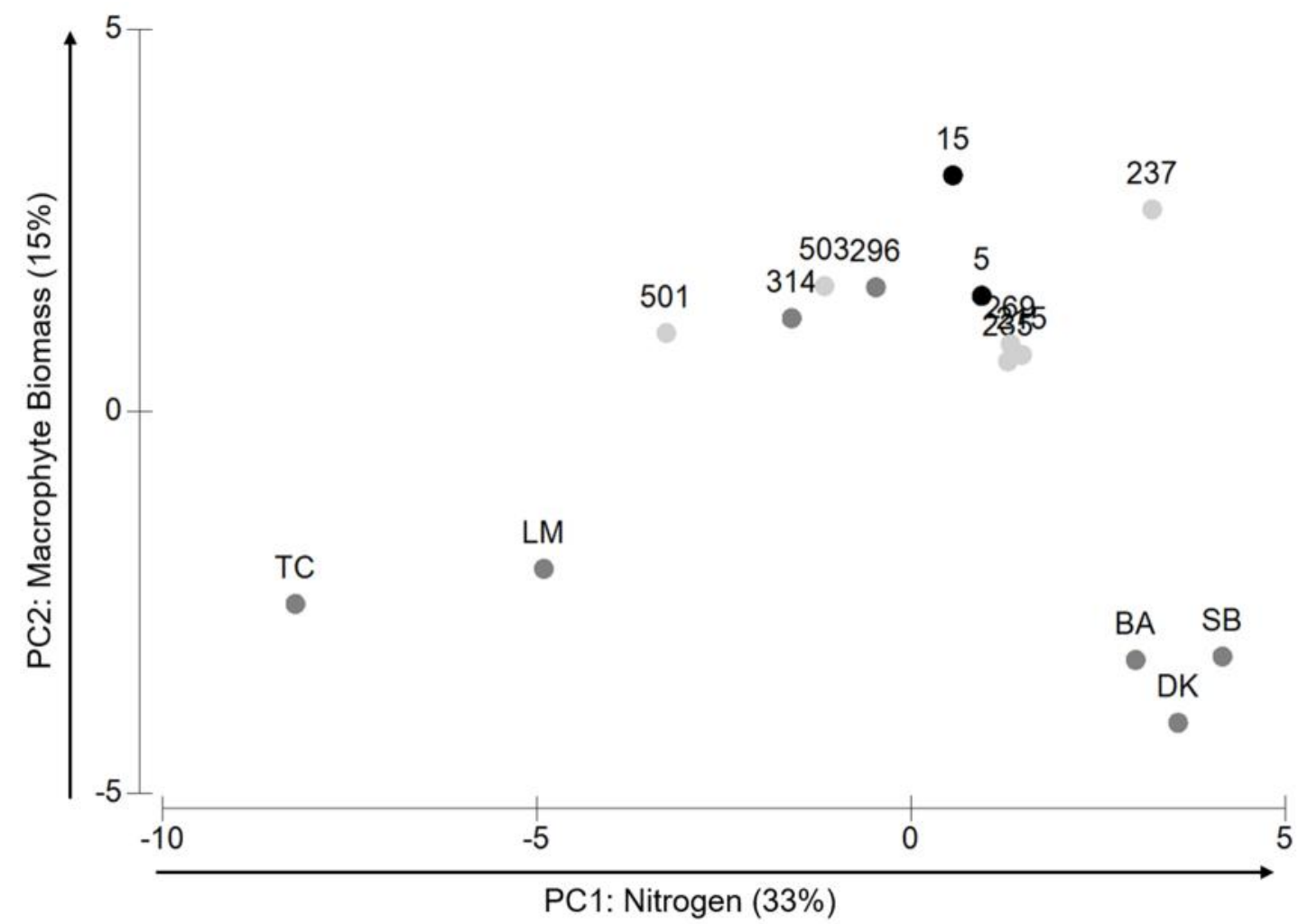

Figure 2.6. Biplot of first and second principle components explaining 53\% of the variation in environmental data. Nitrogen concentration (PC1) explains $35 \%$ of the variation. Hardbottom community (octocoral density) (PC2) explains 18\% of the variation. 


\section{LITERATURE CITED}

Altermatt F, Alther R, Fišer C, Jokela J, Konec M, Küry D, Mächler E, Stucki P, Westram AM. 2014. Diversity and distribution of freshwater amphipod species in Switzerland (Crustacea: Amphipoda). PloS one 9: e110328.

Anderson MJ, Gorley RN, Clarke KR. 2008. PERMANOVA+ for PRIMER: Guide to Software and Statistical Methods. 2008214.

Baggett LP, Heck KL, Frankovich TA, Armitage AR, Fourqurean JW. 2012. Stoichiometry, growth, and fecundity responses to nutrient enrichment by invertebrate grazers in sub-tropical turtle grass (Thalassia testudinum) meadows. Marine Biology 160: 169-180.

Barnard JL, Sandved K, Thomas JD. 1991. Tube-building behavior in Grandidierella, and two species of Cerapus. Hydrobiologia 223: 239-254.

Bousfield EL, Hoover PW. 1997. The amphipod superfamily Corophioidea on the Pacific coast of North America: 5. Family Corophiidae: Corophiinae, new subfamily: systematics and distributional ecology. Amphipacifica 3: .

Bousfield EL. 1973. Shallow-Water Gammaridean Amphipoda of New England. Cornell University Press.

Campbell J, Fourqurean J. 2009. Interspecific variation in the elemental and stable isotope content of seagrasses in South Florida. Marine Ecology Progress Series 387: 109-123.

Childers DL. 2006. A synthesis of long-term research by the Florida Coastal Everglades LTER Program. Hydrobiologia 569: 531-544.

Clarke KR, Gorley RN, Somerfield PJ, Warwick RM. 2014. Change in marine communities: an approach to statistical analysis and interpretation, 3rd edition. .

Clarke KR. 1993. Non-parametric multivariate analyses of changes in community structure. Austral Ecology 18: 117-143.

Collado-Vides L, Caccia VG, Boyer JN, Fourqurean JW. 2007. Tropical seagrassassociated macroalgae distributions and trends relative to water quality. Estuarine, Coastal and Shelf Science 73: 680-694.

Cruz-Rivera E, Hay ME. 2000. Can quantity replace quality? Food choice, compensatory feeding, and fitness of marine mesograzers. Ecology 81: 201-219. 
de-la-Ossa-Carretero JA, Del-Pilar-Ruso Y, Giménez-Casalduero F, Sánchez-Lizaso JL, Dauvin J-C. 2012. Sensitivity of amphipods to sewage pollution. Estuarine, Coastal and Shelf Science 96: 129-138.

Douglass JG, Duffy JE, Bruno JF. 2008. Herbivore and predator diversity interactively affect ecosystem properties in an experimental marine community. Ecology letters 11: 598-608.

Douglass JG, France KE, Paul Richardson J, Duffy JE. 2010. Seasonal and interannual change in a Chesapeake Bay eelgrass community: Insights into biotic and abiotic control of community structure. Limnology and Oceanography 55: 1499-1520.

Duarte C, Navarro JM, Acuña K, Gómez I. 2010. Feeding preferences of the sandhopper Orchestoidea tuberculata: the importance of algal traits. Hydrobiologia 651: 291303.

Fourqurean JW, Robblee MB. 1999. Florida Bay: A history of recent ecological changes. Estuaries 22: 345.

Fourqurean, J.W. \& Rutten L.M. 2003. Competing goals of spatial and temporal resolution: monitoring seagrass communities on a regional scale. Pp 257-288 in: Busch, D. E. and J.C. Trexler, eds. Monitoring ecosystems: interdisciplinary approaches for evaluating ecoregional initiatives. Island Press, Washington, D. C. $447 \mathrm{pp}$

Fourqurean JW, Willsie A, Rose CD, Rutten LM. 2001. Spatial and temporal pattern in seagrass community composition and productivity in south Florida. Marine Biology 138: $341-354$.

Fourqurean JW, Zieman JC. 1992. Phosphorus limitation of primary production in Florida Bay: evidence from C:N:P ratios of the dominant seagrass Thalassia testudinum. Limnology and Oceanography 37: 162-171.

Fourqurean JW, Zieman JC. 2002. Nutrient content of the seagrass Thalassia testudinum reveals regional patterns of relative availability of nitrogen and phosphorus in the Florida Keys USA. Biogeochemistry 61: 229-245.

Frankovich TA, Fourqurean JW. 1997. Seagrass epiphyte loads along a nutrient availability gradient, Florida Bay, USA. Marine Ecology Progress Series 159: 3750 .

Gesteira JLG, Dauvin J-C. 2000. Amphipods are good bioindicators of the impact of oil spills on soft-bottom macrobenthic communities. Marine Pollution Bulletin 40: 1017-1027. 
Guerra-García JM, García-Gómez JC. 2001. The spatial distribution of Caprellidea (Crustacea: Amphipoda): A stress bioindicator in Ceuta (North Africa, Gibraltar Area). Marine Ecology 22: 357-367.

Harrell FE, with contributions from Charles Dupont and many others. 2016. Hmisc: Harrell Miscellaneous. R package version 3.17-2. http://CRAN.Rproject.org/package $=$ Hmisc

Heck KL, Pennock JR, Valentine JF, Coen LD, Sklenar SA. 2000. Effects of nutrient enrichment and small predator density on seagrass ecosystems: An experimental assessment. Limnology and Oceanography 45: 1041-1057.

Heck KL, Valentine JF, Island D. 2007. The primacy of top-down effects in shallow benthic ecosystems. Estuaries and Coasts 30: 371-381.

Heck KL, Valentine JF. 2006. Plant-herbivore interactions in seagrass meadows. Journal of Experimental Marine Biology and Ecology 330: 420-436.

Heck KL, Wetstone GS. 1977. Habitat complexity and invertebrate species richness and abundance in tropical seagrass meadows. Journal of Biogeography 4: 135-142.

Jiménez EG, Hauxwell J, Heckscher E, Rietsma C, Valiela I. 1996. Selection of nitrogenenriched macroalgae (Cladophora vagabunda and Gracilaria tikvahiae by the herbivorous amphipod Microdeutopus gryllotalpa. Biological Bulletin 191: 323324.

Klein III CJ, Orlando Jr. SP. 1994. A spatial framework for water-quality management in the Florida Keys National Marine Sanctuary. Bulletin of Marine Science 54: 10361044.

Lecroy SE. 2002. An illustrated identification guide to the nearshore marine and estuarine gammaridean amphipoda of Florida. .

Lewis FG, Stoner AW. 1983. Distribution of macrofauna within seagrass beds: an explanation for patterns and abundance. Bulletin of Marine Science 33: 296-304.

Lewis FG. 1987. Crustacean epifauna of seagrass and macroalgae in Apalachee Bay, Florida, USA. Marine Biology 94: 219-229.

Neckles HA, Wetzel RL, Orth RJ. 1993. Relative effects of nutrient enrichment and grazing on epiphyte macrophyte dynamics. Oecologia 93: 285-295.

Nelson WG, Cairns KD, Virnstein RW. 1982. Seasonality and spatial patterns of seagrass-associated amphipods of the Indian River Lagoon, Florida. Bulletin of Marine Science 32: 121-129. 
Nelson WG. 1980. A comparative study of amphipods in Seagrasses from Florida to Nova Scotia. Bulletin of Marine Science 30: 80-89.

Nelson WG. 1979. An analysis of structural pattern in an eelgrass (Zostera marina L.) amphipod community. Journal of Experimental Marine Biology and Ecology 39: 231-264.

Noss RF. 1990. Indicators for monitoring biodiversity: A hierarchical approach. Conservation Biology 4: 355-364.

Oksanen J, Blanchet FG, Kindt R, Legendre P, Minchin PR, O’Hara RB, Simpson GL, Solymos P, Henry M, Stevens H, Wagner H. 2015. vegan: Community Ecology Package. R package version 2.3-2. http://CRAN.R-project.org/package=vegan

Orth RJ, van Montfrans J. 1984. Epiphyte-seagrass relationships with an emphasis on the role of micrograzing: a review. Aquatic Botany 18: 43-69.

Rainbow PS, White SL. 1989. Comparative strategies of heavy metal accumulation by crustaceans: zinc, copper and cadmium in a decapod, an amphipod and a barnacle. Hydrobiologia 174: 245-262.

Reish DJ, Barnard JL. 1079. Amphipods (Arthropoda: Crustacea: Amphipoda). In: CWJ Hart and SLH Fuller, editor. Pollution Ecology of Estuarine Invertebrates New York: Academic Press. p. 345-370.

Russo AR. 1987. Role of habitat complexity in mediating predation by the gray damselfish Abudefduf sordidus on epiphytal amphipods. Marine Ecology Progress Series 36: 101-105.

Schneider FI, Mann KH. 1991. Species specific relationships of invertebrates to vegetation in a seagrass bed. II. Experiments on the importance of macrophyte shape, epiphyte cover and predation. Journal of Experimental Marine Biology and Ecology 145: 119-139.

Spellerberg IF. 1991. Monitoring Ecological Change. New York: Press Syndicate of the University of Cambridge.

Stoner AW, Lewis FG. 1985. The influence of quantitative and qualitative aspects of habitat complexity in tropical sea-grass meadows. Journal of Experimental Marine Biology and Ecology 94: 19-40.

Stoner AW. 1980a. Perception and choice of substratum by epifaunal amphipods associated with seagrasses. Marine Ecology Progress Series 3: 105-111. 
Stoner AW. 1980b. The role of seagrass biomass in the organization of benthic macrofaunal assemblages. Bulletin of Marine Science 30: 537-551.

Thomas JD. 1993. Biological monitoring and tropical biodiversity in marine environments: a critique with recommendations, and comments on the use of amphipods as bioindicators. Journal of Natural History 27: 795-806.

Tilman D, Pacala S. 1993. The maintenance of species richness in plant communities. In: RE Ricklefs and D Schluter, editor. Species diversity in ecological communities Chicago, Illinois, USA: University of Chicago Press. p. 13-25.

Virnstein RW, Howard RK. 1987. Motile epifauna of marine macrophytes in the Indian River Lagoon, Florida. I. Comparisons among three species of seagrasses from adjacent beds. Bulletin of Marine Science 41: 1-12.

Young DK, Buzas MA, Young MW. 1976. Species densities of macrobenthos associated with seagrass: a field experimental study of predation. Journal of Marine Research 34: 577-592.

Young DK. 1978. Regulation of species densities of seagrass-associated macrobenthos: evidence from field experiments in the Indian River estuary, Florida. Journal of Marine Research 36: 569-593. 
CHAPTER III

GAMMARIDEAN AMPHIPODS IN FLORIDA BAY AND THEIR UTILITY AS INDICATORS IN A SUBTROPICAL SEAGRASS MONITORING PROGRAM 


\begin{abstract}
Amphipod crustaceans are widely used as bioindicators of environmental conditions or disturbances in temperate ecosystems but are not as widely used in tropical ecosystems. A clear understanding of the drivers of amphipod spatial and temporal distribution is necessary before amphipods can be incorporated into monitoring programs and used as bioindicators. We monitored amphipod community structure for a year in Florida Bay to assess the relationship between amphipod community composition and environmental variables. Cluster analyses of multivariate amphipod communities identified spatial differences in community composition. Amphipod communities in eastern sites (Bob Allen Keys, Little Madiera, Trout Cove, and Duck Key) were more similar to each other than to the western site community (Sprigger Bank). Within the eastern sites, sites located in the central bay (Bob Allen Keys and Duck Key) were different from sites in the northern bay (Trout Cove and Little Madiera). The third grouping differentiated between Sprigger Bank communities by seasons: the January community was different from communities in April, July, and October. Using principle components (PC) analysis, we reduced our environmental dataset from 33 variables to 4 principle components, which explained $73 \%$ of the variation in the original environmental data. We then used PC scores to identify correlations between univariate density and diversity measures and environmental components. The four components were representative of macrophyte density (explains $37 \%$ of the variation), freshwater input (12\%), nitrogen availability (13\%), and seasonality (11\%). Amphipod density was negatively correlated with macrophyte density and positively correlated with watercolumn nitrogen. Macrophyte density was higher at Sprigger Bank, which should support
\end{abstract}


a dense amphipod community according to previous studies. However, sediments were finer at eastern sites and coarse at Sprigger Bank limiting the abundances of tubedwelling, or domicolous, amphipods at the latter site. Conversely, domicolous amphipods dominated communities at eastern sites. Water-column nitrogen may impact nitrogen content of epiphytic microalgae upon which amphipods graze, thereby resulting in an increase in amphipod density in areas of higher nitrogen availability. Amphipod richness, diversity, and dominance were not correlated with macrophyte density or nitrogen components, but were negatively correlated with freshwater input. As a result, communities at Trout Cove and Little Madiera, near sources of terrestrial runoff, had more diverse communities with lower species dominance. Amphipod density and univariate diversity metrics were not significantly correlated with the seasonality component. We recommend continued monitoring of amphipod communities in Florida Bay to better understand environmental drivers regulating their spatial and temporal distribution.

Keywords: Florida Bay, amphipod, spatial distribution, temporal distribution, bioindicator, environmental indicator

\section{Highlights}

- Analyses of environmental drivers of amphipod community structure were conducted

- Amphipod communities differ spatially despite similar seagrass composition

- 4 principle components describe $73 \%$ of the variation in the environmental dataset 
- Amphipod density positively correlated with nitrogen, negatively with plant density

- Richness, diversity, and dominance were negatively correlated with freshwater input.

\section{Introduction}

Understanding the spatial and temporal constraints of organisms and the biotic and abiotic drivers regulating community composition are important first steps in establishing a baseline of species distribution and community composition in a region. Coastal marine ecosystems are dynamic regions that are at the forefront of anthropogenic disturbances such as nutrient input from runoff and mechanical damage from boating, dredging, and trampling (Short \& Wyllie-Echeverria 2009; Short et al. 2011).

Establishing a baseline for future studies and understanding the mechanisms driving changes in species distributions and community structure are important when developing a management plan (Thomas 1993). The major goal of monitoring programs is to effectively sample a habitat to maximize information gathered and minimize the destructive impacts and monetary costs of sampling (Thomas 1993; Fourqurean \& Rutten 2003). Identifying species as indicators of degraded conditions can make monitoring programs more effective in assessing the overall health and functioning of an ecosystem than monitoring programs not utilizing indicator species.

Monitoring vegetated habitats provides a great deal of information regarding the health of an ecosystem. Macrophytes, including algae, respond to disturbances at 
different timescales providing both short- and long-term snapshots of ecosystem health. Seagrasses assimilate available nutrients over long periods of time (i.e., months or years) (Frankovich \& Fourqurean 1997, reviewed in Orth et al. 2006); whereas, some species of macro- and micro-algae respond very quickly to elevated nutrient concentrations (Rosenberg \& Ramus 1984, Hein et al. 1995, Worm \& Sommer 2000). As such, algae are better indicators of more recent changes in nutrient availability than seagrasses in some ecosystems. Some species are intolerant to excessive nutrient availability while others are tolerant to high water-column nutrient concentrations and are typically found in high abundances at sites where nutrient inputs are high (e.g., the macrophytes Typha spp. (Jensen et al. 1995; Craft \& Richardson 1997, Craft et al. 2007) and Halodule wrightii (Howard et al. 2016), and the alga Anadyomene spp. (Collado-Vides et al. 2013)). The specific tolerances of different species of macrophytes to excessive nutrients, for example, can impact their distribution. Including both groups of benthic vegetation in monitoring programs can provide valuable information on short- and long-term bottomup control (resource availability).

However, how disturbances impact the functioning of an ecosystem, including both top-down (consumers) and bottom-up (resources) forces, is unclear from macrophyte information alone. Amphipods provide an integrated approach to ecosystem monitoring because they provide information about the interaction of both top-down and bottom-up controls. They graze on epiphytic and benthic microalgae (Duffy \& Hay 2000), and are an important food source to many different species of fish, thereby providing information on the functioning of higher trophic levels (Brook 1977; Young \& Young 1976; Young et al. 1978). Furthermore, animals are sensitive to different types of 
disturbances than plants. For example, amphipods are very sensitive to contamination related to oil spills (Gesteira \& Dauvin 2000); whereas, seagrasses are more tolerant of these marine disturbances (Wilson \& Ralph 2008). Including amphipod sampling in a seagrass and macroalgae monitoring program may provide a cost effective way to get a more comprehensive assessment of ecosystem health and overall functioning.

Amphipods have been long used as indicators of water quality in temperate, coastal environments (Reish \& Barnard 1979). They respond to disturbances such as elevated nutrient levels, heavy metal pollution, salinity and dissolved oxygen changes, oil pollution, turbidity, fishing (Reish \& Barnard 1979), and are sensitive to mechanical disturbances (Dahl 1948). As such, amphipods have been identified as important bioindicators in estuarine ecosystems because they meet the criteria for good bioindicator species: they are ecologically important, abundant, have specific niches, are sensitive to pollutants, and have low dispersal abilities (Thomas 1993). Despite their ecological importance and proven usefulness in management programs, they are underused in tropical monitoring programs.

Amphipods are ubiquitous in terrestrial, freshwater, and marine habitats worldwide and have species-specific tolerances to abiotic and biotic factors. Little is known about the general ecology of many species, however, limiting the current potential for amphipods to be included in monitoring programs as indicator species. Recent studies have assessed their community composition and species distributions to create a baseline from which researchers can determine the utility of including amphipod sampling as a potential monitoring tool (Altermatt et al. 2014). Similarly, we surveyed gammaridean amphipod communities at five sites across four seasons in Florida Bay, a large (ca. 2000 
$\mathrm{km}^{2}$ ) embayment with strong environmental gradients (see Fourqurean and Robblee 1999 for a description of the prevailing gradients). The main objectives in this study were to: I. determine if there are differences in amphipod density, species richness, Shannon-Wiener diversity, inverse Simpson's dominance (hereafter referred to as amphipod density and diversity metrics), and multivariate community composition across five sites in Florida Bay and across four months (January, April, July, and October); II. determine if the annual environmental climates differ by site using benthic vegetation and seagrass nutrient data collected as part of the Florida Coastal Everglades Long Term Ecological Research (FCE-LTER) program. We used nutrient data from both datasets because water quality nutrient analyses are an instantaneous measure of nutrient concentrations and are often variable; whereas, seagrass nutrient content is accumulated over longer time scales thereby proving information on the long-term nutrient climate (Frankovich \& Fourqurean 1997, Fourqurean and Rutten 2003, Burkholder et al. 2007). Our final objective was to III. determine the environmental drivers of amphipod density and diversity metrics, and multivariate community composition.

Systematic monitoring of seagrass ecosystems in Florida Bay began in the 1980's, and since 2000 this monitoring has been an critical component of the FCE-LTER. Florida Bay is important economically, supporting commercial and recreational fishing and boating, and is currently being affected by Everglades restoration activities and other long-term factors, including climate change and sea-level rise. Furthermore, because the FCE-LTER seagrass sites are situated along gradients of seagrass complexity (shoot density, species composition, and canopy height), phosphorus availability (Fourqurean \& Zieman 1992), and salinity climate (McIvor et al. 1994), characterizing the mesograzer 
populations would inform researchers of current amphipod community composition and species diversities along multiple biotic and abiotic conditions.

\section{Materials and Methods}

Site Description

Florida Bay is a shallow, oligotrophic bay that comprises approximately $30 \%$ of Everglades National park (NRC 2002). The FCE-LTER program began in 2000 to monitor ecosystem responses (primary productivity, and trophic, soil, nutrient disturbance, and landscape-scale dynamics) to the process of restoring freshwater sheetflow through south Florida (Childers 2006). As part of the FCE-LTER monitoring program, data on the benthic communities (macrophyte density, nutrient and isotope ratios, sediment type, abiotic data) are collected bimonthly throughout the year. For this study, we collected samples at five sites along the FCE-LTER transect to investigate environmental drivers of amphipod community structure. Replicate $(n=5)$ samples were collected at Trout Cove (TS/Ph 7), Little Madeira (TS/Ph 8), Duck Key (TS/Ph 9), Bob Allen Keys (TS/Ph 10), and Sprigger Bank (TS/Ph 11) in January, April, July, and October of 2014 (Fig. 3.1).

Both Florida Bay and the Everglades are phosphorus limited ecosystems (Fourqurean \& Zieman 1992; Noe et al. 2001). Florida Bay has limited hydrologic connectivity (Boyer et al. 1999), restricting connectivity among basins and among ecosystems (freshwater Everglades, Gulf of Mexico, and Atlantic Ocean). Multiple environmental gradients exist across Florida Bay as a result of its compartmentalized 
nature. Nitrogen and phosphorus concentrations in the water column decrease from northern to southern Florida Bay (Fourqurean et al. 1993, Rudnick et al. 1999). Spatial patterns in nutrient ratios $(\mathrm{N}: \mathrm{P}$ and $\mathrm{C}: \mathrm{P})$ in the water column and seagrass leaves are significantly higher in western than eastern Florida Bay, suggesting that the Gulf of Mexico is a source of phosphorus for benthic macrophytes (Fourqurean \& Zieman 1992; Fourqurean et al. 1993; Boyer et al. 1997). Northeastern Florida Bay has limited water exchange with the Atlantic Ocean and can result in hypersaline conditions during the dry season or hyposaline conditions during the wet seasons (McIvor et al. 1994, Nuttle et al 2000).

Macrophyte Sampling

Abundance and species composition of macrophytes and other benthic taxa (including octocorals, scleractinean corals, and sponges) were assessed as percent cover at 10 randomly selected $0.25 \mathrm{~m}^{2}$ quadrats along a permanent $50 \mathrm{~m}$ transect at each site using a modified Braun-Blanquet technique (Fourqurean et al 2001). Each taxon within each quadrat is assigned a Braun-Blanquet score between 0 and 5, where 0.1 indicates a solitary individual is covering $\leq 5 \%$ of the quadrat, 0.5 indicates a few individuals covering $5 \%, 1$ indicates numerous individuals covering $\leq 5 \%, 2$ indicates $5 \%-25 \%$ cover, 3 indicates $25 \%-50 \%$ cover, 4 indicates $50 \%-75 \%$ cover, and 5 indicates $75 \%-$ $100 \%$ cover. Braun-Blanquet scores were then used to estimate density of each taxon $\left(\right.$ Density $\left._{i}\right)$ present, calculated as follows:

$$
\operatorname{Density~}_{i}=\frac{\left(\sum_{\mathbf{j}=1}^{n} S_{i j}\right)}{N_{i}} \times \frac{N_{i}}{n}
$$


where $N$ is the number of quadrats sampled at a site in which species $i$ is present, $n$ is the total number of quadrats sampled, and $S_{i j}$ is the Braun-Blanquet score for species $i$ in the $j^{\text {th }}$ quadrat. Abiotic data were collected at each site, including temperature, salinity, and turbidity.

Short shoots from each seagrass species present were collected for analyses of nutrient content in photosynthetic tissues, a long-term indicator of the relative availability of nutrients. Seagrasses were transported on ice to the lab where leaves were scraped free of all epiphyte material using a razor blade. Epiphyte tissue was stored at $-20{ }^{\circ} \mathrm{C}$ in 20 $\mathrm{mL}$ scintillation vials until further processing. Leaf morphology was measured for each short shoot collected, and seagrasses were dried at $60{ }^{\circ} \mathrm{C}$ to a constant weight. Dried seagrasses were weighed and homogenized for nutrient analyses. Total phosphorus content was determined using a dry-oxidation, acid hydrolysis extraction with calorimetric analysis (Fourqurean \& Zieman 1992). Carbon and nitrogen content were analyzed using a CHN analyzer (Fisions NA1500). Chlorophyll $a$ content of the adhering epibiont community was used as a proxy for epiphyte biomass. Scraped epiphyte material was lyophilized to obtain a dry weight. Chlorophyll $a$ was extracted for 24-48 hours using $90 \%$ acetone. Chlorophyll $a$ concentrations were determined using a Shimadzu RF5301PC Spectrofluorophotometer. Total epiphyte load was estimated as leaf-specific chlorophyll $a\left(\mu \mathrm{g}\right.$ Chl $a$ leaf area $\left.^{-1}\right)$.

\section{Amphipod Sampling}

A modified Virnstein Grabber (Virnstein \& Howard 1987; Douglass et al. 2008) was used to collect replicate samples $(n=5)$ at each site during each season $\left(\mathrm{N}_{\text {total }}=100\right)$. 
Samples were collected adjacent to the transect at plots with similar macrophyte composition as that within the transect. The Virnstein Grabber samples an area of $0.4 \mathrm{~m}^{2}$ per replicate by removing aboveground biomass and associated epifauna while minimizing the collection of sediments. Seagrass and epifauna were collected in $400 \mathrm{~m}$ mesh filter bags and transported on ice to the laboratory where they were stored at $-20{ }^{\circ} \mathrm{C}$ until processing. Samples were thawed, and any seagrass or macroalgae present were removed. The samples were filtered through a $500 \mathrm{~m}$ sieve and preserved in $5 \%$ formalin. The amphipods in the samples were removed and identified down to the species level (LeCroy 2002) under a dissecting microscope.

Seagrass tissues (living and detrital) and macroalgae collected in the Virnstein Grabber were also dried to a constant weight at $60{ }^{\circ} \mathrm{C}$. Dried vegetation was combusted at $500{ }^{\circ} \mathrm{C}$ for 4 hours to estimate ash free dry weight (AFDW). Amphipod density was calculated by dividing the number of amphipods of each species by g macrophyte AFDW in the $0.4 \mathrm{~m}^{2}$ sampling area.

\section{Environmental dataset}

Water quality data collected as part of the FCE-LTER following the methods of the Water Quality Monitoring and Projection Project of the Florida Keys National Marine Sanctuary (FKNMS) by the Southeast Environmental Research Center at Florida International University (http://serc.fiu.edu/wqmnetwork/) were used. Water quality samples are collected quarterly each year at the same sites and around the same time seagrass monitoring occurs. Methods for field sampling and sample analyses are described in detail in Boyer \& Jones (2002). From this extensive monitoring dataset, we 
used the following water-quality variables: nitrate+nitrite $(\mathrm{NO} \times \mathbf{M})$, nitrate $\left(\mathrm{NO}_{3}{ }^{-} ; \mathrm{M}\right)$, nitrite $\left(\mathrm{NO}_{2}{ }^{-} ; \mathrm{M}\right)$, ammonium $\left(\mathrm{NH}_{4}^{+} ; \mathrm{M}\right)$, total nitrogen $(\mathrm{TN} ; \mathrm{M})$, dissolved inorganic nitrogen (DIN; M), total organic nitrogen (TON; M), total phosphorus (TP; M), soluble reactive phosphorus (SRP; M), total organic carbon (TOC; M), chlorophyll $a$ (CHLa; g) and dissolved oxygen (DO).

Water quality samples in Florida Bay were collected consistently from 2000 through 2008. We averaged data collected across years within each of the four months in which we collected amphipod and seagrass samples as a proxy for current water quality. Seagrasses are long-term integrators water-column nutrients and are unlikely to respond quickly to short-term changes in water quality (Frankovich and Fourqurean 1997). However, animals are more responsive to short-term changes in water quality, but in the absence of current data, averages were used to capture the historical variability in water quality. In addition to average water quality data, we included variables collected as part of the LTER seagrass monitoring in our environmental dataset: depth, turbidity, temperature, nutrient content of seagrass leaves (carbon, nitrogen, phosphorus), epiphyte abundance (chlorophyll $a$ per short shoot), seagrass biomass in $0.4 \mathrm{~m}^{2}$ area (dry weight, and weights of organic and inorganic matter), and macrophyte densities (Thalassia testudinum, Syringodium filiforme, Halodule wrightii, Halimeda spp., Penicillus spp., total density of calcareous green algae, Batophora spp., Laurencia spp., and sponges). 
Statistical Analysis

Rarefied species richness was calculated to standardize the number of individuals sampled across sites (Gotelli \& Colwell 2001) using Primer v.6. Rarefied richness was calculated as follows:

$$
E S_{n}={ }_{i=1}^{S}\left\lfloor 1-\frac{\left(N-N_{i}\right) !(N-n) !}{\left(N-N_{i}-n\right) ! N !}\right.
$$

where the expected number of species $E S$ from a sample of fewer individuals $n$ was calculated using the number of species $S$ with $N$ individuals of species $i$ (Clarke et al. 2014). Shannon-Wiener $(H)$ and inverse Simpson's $(D)$ indices were used to estimated species diversity and dominance, respectively. $H$ and $D$ were calculated as follows:

$$
H=-\sum_{i=1}^{S} p_{i} \log _{b} p_{i} \quad D=\frac{1}{\sum_{i=1}^{S} p_{i}^{2}}
$$

where $p_{i}$ is the proportion of species $i$, and $S$ is the number of species (Oksanen et al. 2016).

For objective I, patterns in amphipod species richness, diversity (Shannon-Weiner index), and dominance (inverse Simpson's index) were evaluated through time (January, April, July, October) using a multivariate analysis of variance (MANOVA) in R Studio (R development core team 2015) using the 'car' package (Fox \& Weisberg 2011). MANOVA was used in lieu of a univariate repeated measures design because replication was low and sphericity, an assumption of repeated measures design, could not reliably be met. Mauchly's test for sphericity reports the test statistic, $W$, and an associated p-value. $W$ ranges between 0 and 1 where a small $W$ indicates a violation of sphericity (Winer et al. 1991), as does a significant $\mathrm{p}$-value $(\mathrm{p}<0.05)$. In our analysis, $W$ was low yet the $\mathrm{p}$ - 
value was not significant. The contradiction between small $W$ and non-significant p-value means we cannot determine if sphericity is met; furthermore, Mauchly's test is unreliable with small datasets (O’Brien \& Kaiser 1985). When sphericity cannot be met, multivariate analyses are recommended (von Ende 2001). In MANOVA seasonal replication was treated as multiple dependent variables and the independent variable was Site ( $\mathrm{n}=5$ sites in Florida Bay). Post-hoc analysis was conducted using univariate analysis of variance (ANOVA) models and Tukey's HSD (von Ende 2001). Diversity indices were $\log (\mathrm{x}+1)$ transformed to meet the normality assumption.

Differences in multivariate community composition across sites and sampling dates were tested using a 2-factor, fully-crossed permutational ANOVA (PERMANOVA). The community data matrix was first square root transformed to suppress the influence of dominant taxa collected (Clarke 1993), and a dissimilarity matrix was calculated using Bray-Curtis dissimilarity. The Bray-Curtis matrix was visualized using non-metric multidimensional scaling (nMDS)(Primer v.6), where points closer together are more similar than distant points. A hierarchical agglomerative cluster analysis with group-average linkage procedure was used to identify similarities in amphipod communities across sites and seasons. Multivariate groupings significant to the $\mathrm{p}<0.05$ level were identified using a similarity profile test (SIMPROF; Clarke et al. 2014). Similarity percentage (SIMPER) analysis was used to determine which species were contributing to the differences among communities within each grouping identified with cluster analysis.

For objective II, a series of 1-way ANOVAs were used to test for differences in each environmental variable across sites. Environmental variables were log or inverse log 
transformed to meet the assumptions of ANOVA. Multivariate analyses were conducted to understand differences in the environmental climate at each site. Environmental data were normalized (z-scores created) to accommodate for different units of measure among environmental variables. A resemblance matrix was calculated using the Euclidean distance between points. Differences between sites and seasons were analyzed using a 2factor PERMANOVA. The interaction term was not analyzed because of a lack of replication at the season level.

We conducted a Spearman's rho rank correlation matrix to determine if environmental variables were correlated (Hmisc package in R; Harrell et al. 2016). Because several variables were highly correlated, we used principle components analysis (PCA) to reduce our original 33 environmental variables to fewer principle components (PCs). The means and ranges of environmental data were standardized by converting them to z-scores, and varimax rotation was used to facilitate interpretation of principle components. To understand the influence of environmental factors on amphipod multivariate community composition, amphipod density, species richness, ShannonWiener diversity index, and inverse Simpson's dominance index (objective III), PC scores at each site and season were calculated and used as independent variables in distance based linear models (DISTLM Primer v.6). DISTLM is analogous to linear multiple regression and was used to determine relationships between amphipod community density data and multivariate environmental data (PC scores). We used distance based redundancy analysis (dbRDA) to visualize the amphipod community data coded by site (letters) and season (shading) as constrained by environmental components. We also used DISTLM to determine the best model of environmental components to 
describe each of the univariate, amphipod density and diversity metrics. We used the 'Best' model selection procedure in the DISTLM analysis which analyzes every combination of the independent variables to find the best fit model, as determined by corrected Akaike Information Criterion (AICc). The model selection procedure was permuted 9999 times.

\section{Results}

In total 3079 amphipods were collected from 18 families and 41 unique species across the four sampling dates. Of these, 22 species from 10 families were collected at Bob Allen Keys, 26 species from 16 families were collected at Duck Key, 8 species from 7 families were collected at Little Madiera, 13 species from 10 families were collected at Sprigger Bank, and 10 species from 5 families were collected at Trout Cove (Fig. 3.2).

Density and Diversity

Individual amphipod species densities varied across sites and sampling times (Fig. 3.2). Annual amphipod density was significantly different across sites (Site main effect in ANOVA $\left.F_{(4,95)}=54.693 ; p<0.01\right)$. Amphipod density at Duck Key was 2.8 times higher than Little Madiera ( $\mathrm{p}=0.03), 3.6$ times higher than Bob Allen $(\mathrm{p}<0.01), 74$ times higher than Sprigger Bank $(\mathrm{p}<0.01)$, and 6.5 times higher than Trout Cove $(\mathrm{p}<0.01$; Table 3.1). Amphipod density at Little Madiera was 25 times higher $(\mathrm{p}<0.01)$, Bob Allen amphipod density was 20 times higher $(\mathrm{p}<0.01)$, and Trout Cove amphipod density was 11 times higher $(\mathrm{p}<0.01)$ than Sprigger Bank. Little Madiera amphipod density was 2.3 times 
higher than Trout Cove ( $\mathrm{p}=0.02)$. Amphipod density was significantly different across sites within each season (p<0.01, Fig. 3.3a-d). In January, amphipod density at Duck Key was 7.7 times higher than Bob Allen Keys $(\mathrm{p}=0.04)$ and 34 times higher than Trout Cove $(\mathrm{p}<0.01)$. Amphipod density at Bob Allen was 77.7 times higher, Duck Key amphipod density was 607 times higher, Little Madiera amphipod density was 113 times higher, and Trout Cove amphipod density was 17 times higher than Sprigger Bank ( $<<0.01$ for all comparisons; Fig. 3.3a). In April, amphipod density at Bob Allen was 45 times higher, Little Madiera was 15 times higher, Trout Cove was 18.8 times higher, and Duck Key was 30 times higher than Sprigger Bank ( $<<0.01$ for all comparisons; Fig. 3.3b). During July sampling, amphipod density at Duck Key was 5.1 times higher than Bob Allen $(\mathrm{p}<0.01)$ and 4 times higher than Trout Cove $(\mathrm{p}=0.01)$. Bob Allen amphipod density was 6 times higher $(\mathrm{p}=0.02)$, Duck Key amphipod density was 31.3 times higher $(\mathrm{p}<0.01)$, Little Madiera amphipod density was 14.7 times higher $(\mathrm{p}<0.01)$, and Trout Cove amphipod density was 7.9 times higher than Sprigger Bank (p<0.01; Fig. 3.3c). In October, amphipod density at Duck Key was 4.6 times higher than Bob Allen Keys $(\mathrm{p}=0.04)$ and 6.6 times higher Trout Cove $(\mathrm{p}<0.01)$. Amphipod density at Bob Allen was 14.5 times higher, Duck Key was 70 times higher, Little Madiera was 30.6 times higher, and Trout Cove was 10.6 times higher than amphipod density at Sprigger Bank $(p<0.01$ for all comparisons; Fig. 3.3d). Amphipod density was significantly different across seasons within each site $(\mathrm{p}<0.01)$. At Bob Allen Keys, amphipod density was 3.4 higher in October $(\mathrm{p}=0.03)$ and 4.3 times higher in April $(\mathrm{p}=0.01)$ than in July. Amphipod density at Duck Key was 5.4 times higher in October than in April ( $\mathrm{p}=0.03)$. At Little Madiera, October amphipod density was 4.7 times higher than April $(\mathrm{p}=0.013)$ and 2.5 
times higher than January ( $\mathrm{p}=0.05)$. At Sprigger Bank, amphipod density was 4 times higher in April $(\mathrm{p}=0.02), 7$ times higher in July $(\mathrm{p}<0.01)$, and 9.8 times higher in October $(\mathrm{p}<0.01)$ than in January.

Annual, species richness was significantly different across sites (Site main effect in $\left.\operatorname{ANOVA~} \mathrm{F}_{(4,95)}=20.276 ; \mathrm{p}<0.001\right)$. Bob Allen had 1.7 more species than Little Madiera, and twice as many species as both Sprigger Bank and Trout Cove (all p $₫ 0.001$ ). Duck Key had twice as many species as Little Madiera, and 2.4 more species than both Sprigger Bank and Trout Cove (all p $₫$ 0.001). Species richness was significantly different across sites within each season ( $\mathrm{p}=0.004$; Fig. 3.3e-h). During January sampling, Bob Allen had 2.6 times more species than Trout Cove $(\mathrm{p}<0.001), 7.9$ times more species than Sprigger Bank $(\mathrm{p}<0.001)$, and 2.3 times more species than Little Madiera $(\mathrm{p}=0.002)($ Fig. 3.3e). Duck Key had 2.7 times more species than Trout Cove $(\mathrm{p}<0.001), 8$ times more species than Sprigger Bank $(\mathrm{p}<0.001)$, and 2.4 times more species than Little Madiera ( $\mathrm{p}=0.001)$. In April, Bob Allen had 2.1 times more species than Trout Cove $(\mathrm{p}=0.015)$, twice as many species as Sprigger Bank $(\mathrm{p}=0.001)$, and 1.7 times more species than Little Madiera ( $\mathrm{p}=0.020)$ (Fig. 3.3f). In July, Duck Key had 3.2 times more species than Trout Cove $(\mathrm{p}<0.001)$, and twice as many species as Bob Allen $(\mathrm{p}=0.022)$ and Little Madiera ( $\mathrm{p}=0.018$; Fig. 3.3g). In October, Duck Key had 2.2 times more species than Little Madeira $(\mathrm{p}=0.001), 1.6$ times more species than Bob Allen $(\mathrm{p}=0.036)$, twice as many species as Sprigger Bank $(\mathrm{p}=0.003)$ and 2.6 times more species than Trout Cove (p<0.001; Fig. 3.3h). Species richness was significantly different across seasons within each site $(\mathrm{p}<0.001)$. At Bob Allen Keys, amphipods were 1.9 more species-rich in April 
than July ( $\mathrm{p}=0.033)$. At Sprigger Bank, amphipods were 5.5 times more species-rich in July than January $(\mathrm{p}=0.005)$.

Annual diversity and species dominance were significantly different across sites (Site main effect in ANOVA $\mathrm{F}_{(4,95)}=20.390, \mathrm{p}<0.001$ for Shannon-Wiener; $\mathrm{F}_{(4,95)}=18.674$, $\mathrm{p}<0.001$ for inverse Simpson). Bob Allen was 1.5 times more diverse than Little Madiera, twice as diverse as Sprigger Bank, and 2.8 times more diverse than Trout Cove (all p $<0.001)$. Duck Key was 1.7 times more diverse than Little Madiera, 2.1 times more diverse than Sprigger Bank, and 3 times more diverse than Trout Cove (all $\mathrm{p}<0.001$ ). Diversity (Fig. 3.3i-1) and dominance (Fig. 3.3m-p) were significantly different across sites within seasons ( $\mathrm{p}<0.001$ for all). In January, Bob Allen was 7.7 times more diverse than Little Madeira $(\mathrm{p}<0.001), 57.5$ times more diverse than Sprigger Bank $(\mathrm{p}<0.001)$, and 9.2 times more diverse than Trout Cove ( $<<0.001$; Fig. 3.3i). Duck Key was 7 times more diverse than Little Madeira ( $\mathrm{p}<0.001$ ), 52.5 times more diverse than Sprigger Bank $(\mathrm{p}<0.001)$, and 8.4 times more diverse than Trout Cove ( $<<0.001$; Fig. 3.3i). Little Madiera was 7.7 times more diverse than Sprigger Bank ( $\mathrm{p}=0.044$ ). In April, Bob Allen was twice as diverse as Sprigger Bank $(\mathrm{p}=0.002)$ and 1.7 times more diverse than Trout Cove ( $\mathrm{p}=0.004$; Fig. 3.3j). Duck Key was 4.3 times more diverse than Trout Cove during July (p<0.001; Fig. 3.3k), and Sprigger Bank was 3 times more diverse than Trout Cove, and ( $\mathrm{p}=0.044$; Fig. 3.3k). In October, Duck Key was 2.7 times more diverse than Trout Cove ( $\mathrm{p}<0.001$ ), 1.5 times more diverse than Bob Allen Keys ( $\mathrm{p}=0.037$; Fig. 3.31), 1.8 times more diverse than Little Madiera $(\mathrm{p}=0.002)$, and 1.6 times more diverse than Sprigger Bank $(\mathrm{p}=0.006)$. Bob Allen Keys was 1.9 times more diverse than Trout Cove $(\mathrm{p}=0.02)$. Diversity and dominance were significantly different across seasons within 
each site ( $\mathrm{p}=0.027$ for Shannon diversity and $\mathrm{p}=0.019$ for inverse Simpson). At Bob Allen Keys, diversity was 1.7 times higher in January than July ( $\mathrm{p}=0.031)$, and 1.7 times higher in April than July ( $\mathrm{p}=0.021)$. July was 1.8 times more diverse than January at Little Madiera ( $\mathrm{p}=0.031$ ). At Sprigger Bank, July was 15 times more diverse January $(\mathrm{p}=0.006)$ and October was 12.6 times more diverse than in January $(\mathrm{p}=0.02)$.

Amphipod community data

Amphipod communities differed significantly across sites $(\mathrm{p}=0.001)$ and seasons $(\mathrm{p}=0.001)$. Non-metric multidimensional scaling of amphipod communities illustrates site and season differences with a stress of 0.12 (Fig. 3.4). Sprigger Bank has the most unique amphipod community of the five sites sampled; whereas, the remaining four sites appear to have amphipod communities more similar to each other. Amphipod communities at Bob Allen and Duck Key are more similar to each other than either site is to Trout Cove or Little Madiera, and vice versa.

The cluster analysis of amphipod community data identified three groups that were significant at the $\mathrm{p}<0.05$ level denoted by black circles at nodes (Fig. 3.5). The strongest difference between groups, as indicated by the low similarity, occurred between central and eastern sites (Little Madiera, Trout Cove, Duck Key, and Bob Allen Keys), and Sprigger Bank. The community composition of these two groups was $95.58 \%$ dissimilar, and SIMPER analysis between these two groupings identified Grandidierella bonnieroides as the species contributing the most to the dissimilarity between groups (20.26\%). Within the eastern and central Florida Bay sites, a significant division was detected between Bob Allen Keys-Duck Keys and Little Madiera-Trout Cove. The 
community composition was $80.44 \%$ dissimilar between these groupings with all sites contributing $<10 \%$ to the dissimilarity between groups. The final division occurred between seasons at Sprigger Bank where January communities were different from communities collected in April, July, and October (Fig. 3.5). The community composition was $78.49 \%$ dissimilar with Erichthonius sp. A (16.86\%), Tethygeneia longleyi (14.8\%), and Ampithoe ramondi (12.3\%) contributing most to the dissimilarity between groups.

Within-site PERMANOVA analyses identified seasons within a particular site that were characterized by a different amphipod community. At Bob Allen, Little Madeira, and Trout Cove, all cross-season comparisons were significantly different ( $\mathrm{p}<0.05$ for all comparisons). All seasons had significantly different amphipod communities at Duck Key, with the exception of the comparison between July and October ( $\mathrm{p}=0.105)$. Interestingly, amphipod communities at Sprigger Bank were consistent throughout the year. The only significant difference detected at Sprigger Bank was the comparison of amphipod communities between January and October $(p=0.022)$. Within-season PERMANOVA analyses identified sites that were characterized by different amphipod communities. In all seasons (January, April, July, and October), all site-level comparisons had significantly different amphipod communities.

Environmental data

A series of 1-way ANOVAs testing differences across sites for each environmental variable (Table 3.2) were conducted. Thalassia testudinum was more dense at Little Madiera than all other sites (LM-BA p=0.005; LM-TC p<0.001; LM-SB 
$\mathrm{p}=0.049 ; \mathrm{LM}-\mathrm{DK} \mathrm{p}=0.008$ ). No T. testudinum was present at Trout Cove. As such, Bob Allen ( $\mathrm{p}=0.002)$, Duck Key $(\mathrm{p}<0.001)$, and Sprigger Bank $(\mathrm{p}<0.001)$ had significantly higher densities of T. testudinum. Penicillus spp. was more dense at Sprigger Bank than Little Madiera ( $\mathrm{p}=0.027)$ and Trout Cove $(\mathrm{p}=0.021)$. Density of total calcareous green algae (CGT in Table 3.2) was significantly higher at Sprigger Bank than any other site (SB-DK $\mathrm{p}=0.018$; SB-BA $\mathrm{p}=0.006$; SB-TC $\mathrm{p}<0.001$; SB-LM $\mathrm{p}<0.001$ ). If assumptions of ANOVA could not be met due to low replication or complete absence of certain macrophyte species, 'na' was reported for the p-value (see Syringodium filiforme, Halodule wrightii, Halimeda spp., Batophora spp., Laurencia spp. and Sponge in Table $3.2)$.

Environmental variables collected at the same time as amphipod samples were significantly different across sites (Table 3.2). The water at Duck Key was significantly deeper than Little Madiera, Sprigger Bank, and Trout Cove (all p<0.001). Bob Allen was significantly deeper than Little Madiera and Trout Cove (both $\mathrm{p}<0.001$ ). Salinity was higher at Sprigger Bank than Little Madiera $(\mathrm{p}=0.043)$ and Trout Cove $(\mathrm{p}=0.015)$. Salinity at Bob Allen was significantly higher than salinity at Little Madiera $(\mathrm{p}=0.015)$ and Trout Cove $(\mathrm{p}=0.005)$. Nutrient content in photosynthetic tissues was significantly different across sites. Leaf nitrogen was significantly higher at Little Madiera $(\mathrm{p}<0.001)$, Trout Cove $(\mathrm{p}=0.004)$, and Duck Key $(\mathrm{p}=0.040)$ than at Sprigger Bank. Patterns in nitrogen content were likely driven by low phosphorus availability, which led to the luxury consumption and storage of nitrogen. Leaf phosphorus content was significantly higher at Sprigger Bank than Bob Allen, Duck Key, Little Madiera (all p<0.001), and Trout Cove ( $\mathrm{p}=0.002)$. Phosphorus content was significantly higher at Trout Cove than 
Bob Allen ( $\mathrm{p}=0.032)$ and Duck Key $(\mathrm{p}=0.019)$. Similar patterns in phosphorus content have previously been documented (Herbert et al. 2009). Macrophyte dry weight (DW; macrophytes collected as part of amphipod sampling) in a $0.04 \mathrm{~m}^{2}$ sampling area was significantly higher at Sprigger Bank than the other sites (all $p<0.001$ ). DW was significantly higher at Trout Cove than Bob Allen or Duck Key (both $\mathrm{p}<0.001$ ), and was higher at Little Madiera than Duck Key ( $p<0.001)$. Macrophyte inorganic matter in 0.04 $\mathrm{m}^{2}$ (weight of ashes) was significantly higher at Sprigger Bank than Bob Allen, Duck Key, and Little Madiera $(\mathrm{p}<0.001)$. Trout Cove had significantly higher inorganic matter than Duck Key ( $\mathrm{p}<0.001)$, Bob Allen $(\mathrm{p}=0.006)$ and Little Madiera $(\mathrm{p}=0.008)$. Macrophyte ash-free dry weight per $0.04 \mathrm{~m}^{2}$ (AFDW; macrophytes collected as part of amphipod sampling) was significantly higher at Sprigger Bank than the other sites ( $<<0.001$ for all comparisons), and was significantly higher at Trout Cove than Duck Key $(\mathrm{p}=0.027)$. No differences were detected across sites for Turbidity, Temperature, leaf carbon content, or epiphyte biomass (chlorophyll $a$ per short shoot).

Average annual water quality variables differed significantly across sites (Table 3.2). Nitrate+nitrite $\left(\mathrm{NO}_{\mathrm{X}}\right)$ was significantly higher at Duck Key than Sprigger Bank and Bob Allen (both $\mathrm{p}<0.001$ ). $\mathrm{NO}_{\mathrm{X}}$ concentrations were higher at Trout Cove than Bob Allen and Sprigger Bank (both $\mathrm{p}<0.001$ ). $\mathrm{NO}_{\mathrm{x}}$ was lower at Sprigger Bank than Bob Allen and Little Madiera (both $\mathrm{p}<0.001)$. Nitrate $\left(\mathrm{NO}_{3}{ }^{-}\right)$concentrations were significantly higher at Duck Key than Sprigger Bank $(\mathrm{p}<0.001)$ and Bob Allen $(\mathrm{p}=0.004) . \mathrm{NO}_{3}{ }^{-}$ concentrations were higher at Trout Cove than Bob Allen $(\mathrm{p}=0.007)$ and Sprigger Bank $(\mathrm{p}<0.001) . \mathrm{NO}_{3}{ }^{-}$was lower at Sprigger Bank than Bob Allen and Little Madiera (both $\mathrm{p}<0.001)$. Nitrite $\left(\mathrm{NO}_{2}^{-}\right)$concentrations were significantly higher at Duck Key than 
Sprigger Bank $(\mathrm{p}<0.001)$ and Bob Allen $(\mathrm{p}=0.004) . \mathrm{NO}_{2}{ }^{-}$concentrations were higher at Trout Cove than Bob Allen $(\mathrm{p}=0.014)$ and Sprigger Bank $(\mathrm{p}<0.001)$. $\mathrm{NO}_{2}{ }^{-}$was lower at Sprigger Bank than Bob Allen and Little Madiera (both $\mathrm{p}<0.001)$. Ammonium $\left(\mathrm{NH}_{4}{ }^{+}\right)$, Dissolved inorganic nitrogen (DIN), Total nitrogen (TN), and Total organic nitrogen (TON) were significantly lower at Sprigger Bank than all other sites $(\mathrm{p}<0.001$ for all comparisons except for SB-DK for TON where $\mathrm{p}=0.009$ ). Total phosphorus (TP) concentration was significantly higher at Sprigger Bank than Bob Allen ( $\mathrm{p}=0.003)$, Duck Key ( $\mathrm{p}=0.012$ ), and Little Madiera $(\mathrm{p}=0.017)$. Soluble reactive phosphorus (SRP) was significantly higher at Little Madiera $(\mathrm{p}=0.004)$ and Trout Cove $(\mathrm{p}=0.024)$ than Sprigger Bank. Total organic carbon (TOC) was significantly lower at Sprigger Bank than all other sites ( $<<0.001$ for all comparisons). TOC was significantly higher at Little Madiera than Bob Allen ( $\mathrm{p}=0.043)$ and Duck Keys $(\mathrm{p}<0.001)$. TOC was significantly higher at Trout Cove than Bob Allen $(\mathrm{p}=0.013)$ and Duck Key $(\mathrm{p}<0.001)$. TOC was significantly higher at Bob Allen ( $\mathrm{p}=0.018)$ than Duck Key. Chlorophyll $a$ in the water-column was significantly higher at Trout Cove than Bob Allen ( $\mathrm{p}=0.040)$, Duck Key $(\mathrm{p}=0.003)$, and Little Madiera ( $\mathrm{p}=0.013)$. No differences were detected across sites for dissolved oxygen. Similar to amphipod communities across Florida Bay, environmental climates differed significantly across sites (PERMANOVA; $\mathrm{p}=0.001)$ and seasons $(\mathrm{p}=0.001)$. We could not test for the interaction between site and season because of a lack of replication at the season level. Environmental variables differed significantly between January and April ( $\mathrm{p}=0.027)$ and July ( $\mathrm{p}=0.017)$, and between April and July ( $\mathrm{p}=0.017)$. Analysis of sites across all seasons identified more significantly different environmental climates than the analysis across seasons. The suite of environmental variables characterizing Bob 
Allen was significantly different from Little Madiera ( $\mathrm{p}=0.03)$, Sprigger Bank ( $\mathrm{p}=0.03)$, and Trout Cove $(\mathrm{p}=0.02)$. Environmental variables were similar between Duck Key and Bob Allen Keys ( $\mathrm{p}=0.063$ ), but significantly different between Duck Key and Little Madiera ( $\mathrm{p}=0.04)$, Sprigger Bank $(\mathrm{p}=0.04)$, and Trout Cove $(\mathrm{p}=0.02)$. The suite of environmental variables was significantly different at Little Madiera than Sprigger Bank $(\mathrm{p}=0.03)$ and Trout Cove $(\mathrm{p}=0.03)$. Sprigger Bank and Trout Cove were characterized by significantly different $(\mathrm{p}=0.03)$ suites of environmental variables as well.

Principle component analysis reduced the environmental dataset to four principle components, which explain $73 \%$ of the variation and are reported here in order of variation explained by each component (Table 3.3; Fig. 3.6). The first principle component explained 38\% of the variation. Variables associated with macrophyte density (Halimeda spp. density, Syringodium filiforme density, total calcareous green macroalgal density, seagrass dry weight, seagrass ash free dry weight, Penicillus spp. density, seagrass ash weight, and sponge density) loaded heavily on the first component. Principle component 2 explained $13 \%$ of the variation. Nitrogen concentration loaded heavily on the second principle component (nitrite+nitrite, nitrate, nitrite, and dissolved inorganic nitrogen). The third principle component explained $12 \%$ of the variation. Variables associated with freshwater input in Florida Bay loaded heavily on the third component (Halodule wrightii density, depth, water-column chlorophyll $a$, and salinity). The final principle component explained $11 \%$ of the variation. Factors associated with seasonality loaded heavily on PC4 (dissolved oxygen, temperature, and salinity).

The DISTLM procedure was used to determine the relationship between multivariate community composition and univariate diversity measures (amphipod 
density, species richness, Shannon-Wiener diversity, and inverse Simpson's dominance) and each of the four principle components. Multivariate amphipod community composition as reported as the density of each species found at each site was negatively correlated with macrophyte density (DISTLM marginal tests $p<0.001$ and explains $24.8 \%$ of the variation alone) along the dbRDA1 axis (Fig. 3.7; $\mathrm{r}=-0.965)$ and positively correlated with the freshwater component (DISTLM marginal tests $\mathrm{p}<0.001$ and explains $18.1 \%$ of the variation alone) along the dbRDA2 axis (Fig. 3.7; $\mathrm{r}=0.965)$. The best model describing the variation in the multivariate community composition, as ranked by AICc values $(\mathrm{AICc}=156.62)$ included the both the macrophyte density and freshwater components, and described $42.9 \%$ of the variation (Fig. 3.7). The second best model (AICc=157.08), included both the macrophyte density and freshwater components as well as the nitrogen concentration component, and described $50.1 \%$ of the variation in amphipod community composition. Models within two AICc units of each other can be considered as statistically similar models (Burnham \& Anderson 2002).

Amphipod density was negatively correlated with macrophyte density (DISTLM marginal tests; $\mathrm{p}=0.002, \mathrm{r}=-0.77$ ) with $47 \%$ of the variation in density explained by this component, and positively correlated with nitrogen availability (DISTLM marginal tests; $\mathrm{p}=0.029, \mathrm{r}=0.54)$ with $23 \%$ of the variation in density explained by this component alone. Amphipod density was not correlated with freshwater input or seasonality (DISTLM). The best model describing amphipod density, as ranked by AICc values, included both the macrophyte component and the nitrogen concentration component, as well as the freshwater component (DISTLM marginal test $\mathrm{p}=0.0 .184, \mathrm{r}=-0.35$ ) and explained $79.8 \%$ of the variation. The model containing all four environmental components had an AICc 
value within two of the best model, and explained $83 \%$ of the variation in amphipod density.

Species richness was negatively correlated with the freshwater component (DISTLM marginal test $\mathrm{p}=0.001, \mathrm{r}=-0.90$ ) with $43 \%$ of the variation in species richness described by this component alone. The best model describing the variability in species richness included the freshwater component and the macrophyte density component (DISTLM marginal test $\mathrm{p}=0.173 ; \mathrm{r}=-0.43$ ) and described $52.8 \%$ of the variation $(\mathrm{AICc}=37.784)$. However, the second and third best models, which had AICc values within two of the best model, included only the freshwater component describing $43 \%$ of the variation $(\mathrm{AICc}=37.810)$ or included the macrophyte component, freshwater component, and nitrogen component (DISTLM marginal test $\mathrm{p}=0.375, \mathrm{AICc}=38.076$ ) describing $59 \%$ of the variation in species richness.

Shannon diversity was negatively correlated with the freshwater component (DISTLM marginal test $\mathrm{p}<0.001, \mathrm{r}=-1.00$ ) with $61.3 \%$ of the variation in Shannon diversity explained by this component alone. Inverse Simpson's dominance index was negatively correlated with the freshwater input component (DISTLM marginal test $\mathrm{p}<0.001 ; \mathrm{r}=-1.00)$ which described $53.8 \%$ of the variation in the Simpson's index. The best model describing the variation in both Shannon diversity and inverse Simpson's index included only the freshwater component. 


\section{Discussion}

Use of organisms as bioindicators requires knowledge of their natural history. The spatial and temporal distribution of species is often variable and must be well understood prior to incorporation into monitoring programs to understand if detected changes in population or community structure are a result of anthropogenic forcing or the natural phenology of the study organism (Noss 1990). In our study, macrophyte density, nitrogen availability, freshwater input, and seasonality described most of the differences observed across sites. As such, amphipod density, richness, diversity, species dominance, and community composition differed both spatially and temporally across Florida Bay. Variation in amphipod density across sites and seasons was driven by macrophyte density, nitrogen concentration, and freshwater input. Species richness was driven by both freshwater input and nitrogen, and diversity and dominance were largely driven by freshwater alone. Community composition was largely driven by macrophyte density and freshwater input. Specifically, amphipod communities were less dense and less diverse where macrophyte communities in Florida Bay were more structurally complex, and they were also less dense and less diverse in variable environments influenced by seasonal freshwater flow. Amphipod densities were higher where nitrogen availability was higher. Our data suggest that amphipod communities do reflect their environment and are good candidates, by definition, for use as bioindicators (Thomas 1993; McGeoch 2007). We argue that sampling amphipod communities in existing management programs can provide valuable information on ecosystem functioning, but more monitoring of 
amphipod communities in Florida Bay is needed to determine if amphipod species or assemblages would be ideal indicators of environmental conditions.

Gammaridean amphipods are common epiphyte grazers in seagrass ecosystems that live in close association with seagrasses and can be considered seagrass dependent. Studies sampling amphipods within seagrass beds found that amphipod densities were higher in core samples that included seagrass tissue as opposed to core samples taken in bare sediment patches within continuous seagrass beds (Lewis \& Stoner 1983). As such, dense seagrass habitats support high richness, diversity, and abundances of amphipods (Heck \& Wetstone 1977; Stoner 1980a; Lewis \& Stoner 1983; Orth et al. 1984). The higher habitat structural complexity associated with higher macrophyte density is hypothesized to provide shelter and protection from predation (Nelson et al. 1982; Young \& Young 1976; Young et al. 1978). Not only do amphipods actively seek out higher density seagrass habitats when given a choice (Stoner 1980b), they also have seagrassspecific preferences (Stoner 1983; Virnstein \& Howard 1987). Amphipod densities are often higher in dense, monotypic Syringodium filiforme beds than other species, because of the plant's higher surface area to weight ratio (Heck \& Orth 1980). Furthermore, amphipod densities in seagrass beds with macroalgae present are often higher (calcareous green algae: Stoner \& Lewis 1985; drift algae: Schneider \& Mann 1991, Holmquist 1994) possibly as a result of increased habitat complexity (Russo 1987).

In Florida Bay, amphipod density was higher at the four eastern sites (Duck Key, Trout Cove, Little Madiera, and Bob Allen Key) and lowest at Sprigger Bank, despite the fact that the macrophyte community was denser and more diverse at Sprigger Bank. Sprigger Bank in western Florida Bay is characterized by dense Thalassia testudinum and 
Syringodium filiforme with abundant calcareous green macroalgae (Zieman et al. 1989).

Duck Key, on the other hand, has the lowest seagrass density of the 5 sites and the highest amphipod density. Knowledge of the dependence of amphipods on seagrasses would have led us to predict higher amphipod density at Sprigger Bank, but this was not borne out by our data. However, sediment type was very different at Sprigger Bank than the other four sites in this study. Sediment at Sprigger Bank was coarse, calcium carbonate sediments largely composed of the skeletal remains of the calcareous macroalgal genera Halimeda spp. and Penicillus spp. (Zieman et al. 1989). Such coarse sediments restrict the recruitment of domicolous, or tube-dwelling, amphipod species, because they require fine sediments to construct their tubes (e.g., Barnard et al. 1991). The dominant species at Sprigger Bank was Tethygeneia longleyi. This species is not domicolous (Bousfield 1973), thereby not restricted from recruiting to an area with coarser sediment. Bob Allen Keys, Duck Key, Little Madiera, and Trout Cove have fine carbonate sediments that are more similar to each other (Zieman et al. 1989). Domicolous amphipods are found in high density at the four eastern sites. For example, amphipods from the families Ampithoidae, Ischyroceridae, and Aoridae are tube-building taxa (Bousfield 1973) found in high densities at one or more of these sites. A few individuals of domicolous species were identified at Sprigger Bank but in very low densities.

Amphipod communities are strongly regulated by top-down control and temporal variations in their density, richness, and diversity have been attributed to predation by pinfish (Lagodon rhomboides) in the southeastern United States (Thayer et al. 1975; Sheridan \& Livingston 1983; Stoner 1979; Nelson 1979a, 1979b). Pinfish have been identified as major amphipod predators with up to $100 \%$ of their gut contents identified 
as amphipod prey during summer months (Nelson 1979b). Negative correlations between pinfish biomass and epifaunal abundance (Thayer et al. 1975) further support the hypothesis that top-down control is driving temporal patterns in amphipod density.

Temporal patterns in amphipod density and diversity indices driven by top-down forces are not as clear in our data as were found in early studies. While Florida Bay is a recognized nursery habitat for pinfish to which pinfish recruit in winter and spring months, grow quickly (as defined by Nelson 1998), and reach high abundance in western regions of the bay (Powell et al. 2007), the average annual density of amphipods was variable. Pinfish have not been collected in northeast and eastern Florida Bay, and are found in very low abundances in central Florida Bay (Powell et al. 2007). As such, predation by pinfish is not likely driving seasonal differences in amphipod densities. However, silver jenny (Eucinostomas gula) are ubiquitous through Florida Bay, are found in high abundances, are known predators of amphipods, and their population densities peak during summer months (Powell et al. 2007). Despite the presence of abundant predators, temporal patterns at four sites were not what would be expected (e.g., lowest densities in summer/fall when predator densities are at a maximum) if amphipod densities were regulated by top-down control of predatory fish. A recent analysis covering several years of seagrass, mesograzer, and predatory fish data showed few temporal patterns in mesograzer density (Douglass et al. 2010). Contrary to early publications, Douglass et al. (2010) found a positive relationship between mesograzer density and fish abundance suggesting that mesograzers are not strongly regulated by topdown control. Though our data are restricted to a single year, temporal patterns, or lack thereof, are similar to those reported in Douglass et al. (2010) suggesting that amphipod 
density and diversity may be driven by bottom-up factors (e.g., food availability, habitat type, abiotic factors like temperature, salinity, and light availability).

Behaviors of the most abundant amphipod species could mask the temporal impact of predators on total amphipod densities. For example, at Sprigger Bank where predator densities have the potential to be higher than the other sites, the most abundant amphipod species was Tethygeneia longleyi. This species inhabits macrophytes near the substrate (Tararam et al. 1986) possibly making them less susceptible to fish predation.

Amphipod tolerance to seasonality of other environmental variables may be driving more of the patterns seen in our study. This study is limited by a lack of seasonal replication in abiotic variables; however, sites have different concentrations of nitrogen in the water column (PC2: $\mathrm{NO}_{\mathrm{X}}, \mathrm{NO}_{3}{ }^{-}, \mathrm{NO}_{2}{ }^{-}$, and $\left.\mathrm{DIN}\right)$. Amphipod density was higher at sites where nitrogen concentrations were higher. Amphipods, when given a choice, selectively graze on nitrogen-rich food sources (Jiménez et al. 1996; Duarte et al. 2010). Furthermore, nitrogen-rich food sources can increase the growth, survivorship, and fecundity of epifauna, including amphipods (Cruz-Rivera \& Hay 2000; Baggett et al. 2013). If epiphytic microalgae are increasing nitrogen uptake as nitrogen becomes more available, this more nitrogen-rich food source could increase the density of grazing amphipods. In a phosphorus-limited system like Florida Bay, the addition of nitrogen alone is unlikely to cause an increase in the abundance of epiphytic microalgae; however, through luxury consumption, epiphytes could continue to assimilate available nitrogen providing a higher-quality food source to amphipods.

Amphipods are often used as environmental indicators of changes in water quality near wastewater outflows and other point-sources of pollution. Species richness and 
abundance is reduced near sewage outfalls (McClelland \& Valiela 1998), and wastewater effluent is attributed to changes in amphipod community structure (Englert et al. 2013). Species-specific sensitivity may occur where burrowing species are more sensitive to enrichment than domicolous species (Guerra-García \& Koonjul 2005; de-la-OssaCarretero et al. 2012). Amphipod communities in the four eastern sites in Florida Bay are dominated by domicolous species in relatively high densities.

Trout Cove and Little Madiera are located nearest to mainland Florida at two major points of freshwater input into Florida Bay. During the rainy season, and especially when major storms pass within close proximity to Florida, salinity at these sites can be very low. For example, after Hurricane Isaac passed by Florida in late August 2012, salinity was recorded at $0.93 \mathrm{psu}$ in Trout Cove and $7.08 \mathrm{psu}$ in Little Madiera, and remained $<20$ psu for 4 months (Fourqurean unpub.data). Amphipod species that live in this region must have elevated tolerance to changes in salinity. Grandidierella bonnieroides, for example, can survive in a range of salinities from $<1$ psu to over $40 \mathrm{psu}$ (Heard 1982). Similarly, Cymadusa compta has been recorded at salinities from 5 psu to 33 psu (Bousfield 1973; Sheridan 1980). As such, G. bonnieroides and C. compta are found in high density in Trout Cove and Little Madiera. Amphipod species with more restricted salinity tolerance would be unable to persist in these nearshore sites. Erichthonius sp. A, for example was found in both Little Madiera and Sprigger Bank; however, in Little Madiera E. sp. A was only present in low density at the end of south Florida's dry season (April and July; July is technically during the wet season but effects of increased freshwater inflow are not detected until the Fall; Duever et al. 1994; Nuttle 
et al. 2000). E. sp. A was present at Sprigger Bank from January-July, where the salinity is more stable due to the close proximity to the Gulf of Mexico.

\section{Conclusions \& Recommendations}

Data presented in this study are meant to develop a baseline of knowledge on amphipod natural history in Florida Bay. Long-term amphipod monitoring will provide the data necessary to understand if variations in spatial and temporal distribution of species is predictable (Holloway \& Stork 1991). Furthermore, to be considered bioindicators we need a clear understanding of the spatial and temporal distribution of species and community composition to have the ability to differentiate between natural and anthropogenically-induced variation (Noss 1990). We recommend monitoring water quality variables and amphipod communities consistently to include interannual replication of this analysis. For amphipods to be included as indicators in seagrass monitoring programs, more information is needed on their relationship with abiotic and biotic factors across Florida Bay. We need to develop a better understanding of the natural history of amphipod communities in Florida Bay before they can effectively be used as environmental indicators.

\section{Acknowledgements}

This work was supported by the FCE-LTER program (NSF/OCE-9910514).

Christina Currais, Rebecca Valls, and Christian Lopes helped process samples in the lab and provided comedic relief in the field. Lauren Yeager provided advice on statistical analyses. Special thanks to Sara LeCroy for teaching J. L. S. the art of amphipod 
identification, and to Keith McGuinness who both provided the public with PRIMER tutorials on YouTube and responded to comments. Dr. Brett Jestrow loaned J.L.S. space and microscope time in the imaging lab at Fairchild Tropical Botanic Gardens. This is contribution \# x of the Marine Education and Research Center of the Institute for Water and the Environment at Florida International University. 


\section{Tables}

Table 3.1. Mean \pm S.E. of amphipod density, species richness, Shannon-Wiener index, and inverse Simpson's Dominance index by site and season.

\begin{tabular}{|c|c|c|c|c|c|}
\hline & \multicolumn{5}{|c|}{ Density } \\
\hline & January & April & July & October & Annual \\
\hline Bob Allen & $101.51 \pm 28.68$ & $234.53 \pm 55.95$ & $55.35 \pm 21.52$ & $185.50 \pm 53.08$ & $144.25 \pm 25.27$ \\
\hline Duck Key & $790.16 \pm 164.54$ & $156.08 \pm 51.23$ & $282.41 \pm 51.04$ & $844.99 \pm 228.81$ & $518.41 \pm 96.39$ \\
\hline Little Madeira & $146.97 \pm 45.44$ & $78.66 \pm 10.89$ & $132.14 \pm 28.14$ & $367.29 \pm 58.78$ & $181.27 \pm 31.30$ \\
\hline Sprigger Bank & $1.34 \pm 0.80$ & $5.20 \pm 0.96$ & $9.15 \pm 1.73$ & $12.82 \pm 4.39$ & $7.13 \pm 1.49$ \\
\hline \multirow[t]{3}{*}{ Trout Cove } & $22.74 \pm 4.94$ & $97.73 \pm 23.65$ & $71.03 \pm 18.52$ & $127.30 \pm 66.58$ & $79.70 \pm 18.97$ \\
\hline & \multicolumn{5}{|c|}{ Rarefied Richness } \\
\hline & January & April & July & October & Annual \\
\hline Bob Allen & $6.28 \pm 0.37$ & $6.69 \pm 0.72$ & $3.60 \pm 1.12$ & $4.07 \pm 0.30$ & $5.16 \pm 0.45$ \\
\hline Duck Key & $6.40 \pm 0.93$ & $4.75 \pm 1.28$ & $7.09 \pm 0.61$ & $6.37 \pm 0.89$ & $6.15 \pm 0.48$ \\
\hline Little Madeira & $2.71 \pm 0.45$ & $3.92 \pm 0.20$ & $3.49 \pm 0.21$ & $2.94 \pm 0.04$ & $3.11 \pm 0.14$ \\
\hline Sprigger Bank & $0.80 \pm 0.37$ & $2.00 \pm 0.45$ & $4.40 \pm 0.98$ & $3.20 \pm 0.58$ & $2.60 \pm 0.43$ \\
\hline \multirow[t]{3}{*}{ Trout Cove } & $2.40 \pm 0.51$ & $3.17 \pm 0.21$ & $2.20 \pm 0.20$ & $2.47 \pm 0.33$ & $2.56 \pm 0.18$ \\
\hline & \multicolumn{5}{|c|}{ Shannon-Wiener } \\
\hline & January & April & July & October & Annual \\
\hline Bob Allen & $1.66 \pm 0.05$ & $1.71 \pm 0.13$ & $0.99 \pm 0.27$ & $1.14 \pm 0.06$ & $1.38 \pm 0.10$ \\
\hline Duck Key & $1.58 \pm 0.12$ & $1.20 \pm 0.32$ & $1.70 \pm 0.10$ & $1.64 \pm 0.17$ & $1.53 \pm 0.10$ \\
\hline Little Madeira & $0.64 \pm 0.18$ & $0.95 \pm 0.05$ & $1.09 \pm 0.05$ & $0.93 \pm 0.05$ & $0.90 \pm 0.06$ \\
\hline Sprigger Bank & $0.08 \pm 0.08$ & $0.51 \pm 0.22$ & $1.20 \pm 0.28$ & $1.01 \pm 0.16$ & $0.70 \pm 0.14$ \\
\hline \multirow[t]{3}{*}{ Trout Cove } & $0.53 \pm 0.16$ & $0.59 \pm 0.09$ & $0.41 \pm 0.04$ & $0.60 \pm 0.07$ & $0.53 \pm 0.05$ \\
\hline & \multicolumn{5}{|c|}{ Inverse Simpson } \\
\hline & January & April & July & October & Annual \\
\hline Bob Allen & $4.60 \pm 0.25$ & $4.91 \pm 0.57$ & $2.98 \pm 0.99$ & $2.68 \pm 0.19$ & $3.79 \pm 0.35$ \\
\hline Duck Key & $4.15 \pm 0.48$ & $3.39 \pm 0.72$ & $4.35 \pm 0.63$ & $4.41 \pm 0.52$ & $4.07 \pm 0.29$ \\
\hline Little Madeira & $1.73 \pm 0.27$ & $2.27 \pm 0.13$ & $2.68 \pm 0.15$ & $2.34 \pm 0.14$ & $2.26 \pm 0.11$ \\
\hline Sprigger Bank & $0.66 \pm 0.28$ & $1.72 \pm 0.34$ & $3.48 \pm 0.81$ & $2.73 \pm 0.41$ & $2.15 \pm 0.34$ \\
\hline Trout Cove & $1.54 \pm 0.18$ & $1.52 \pm 0.17$ & $1.31 \pm 0.05$ & $1.57 \pm 0.08$ & $1.49 \pm 0.06$ \\
\hline
\end{tabular}


Table 3.2. Mean \pm S.E. of environmental variables and results of 1-way ANOVA for each variable across sites. Units of measure listed here in parentheses. Thalassia testudinum (BB score), Syringodium filiforme (BB score), Halodule wrightii (BB score), Halimeda spp. (BB score), Penicillus spp. (BB score), Batophora spp. (BB score), Laurencia spp. (BB score), sponge (BB score), CGT (BB score), Depth (ft), Turbidity (NTU), Temperature $\left({ }^{\circ} \mathrm{C}\right)$, Salinity (PSU), N (\%), C (\%), P (\%), Epiphyte biomass (chl $a$ per seagrass short shoot), Dry Weight (DW in $\mathrm{g}$ of seagrass biomass collected with amphipods), Inorganic matter (weight in $\mathrm{g}$ of ashes from combusted DW), and Organic matter (weight in $\mathrm{g}$, ash-free dry weight), Nitrate+Nitrite $\left(\mathrm{NO}_{\mathbf{X}} ; \mathrm{M}\right)$, nitrate $\left(\mathrm{NO}_{3}{ }^{-} ; \mathrm{M}\right)$, nitrite $\left(\mathrm{NO}_{2} ; \mathrm{M}\right)$, ammonium $\left(\mathrm{NH}_{4}{ }^{+} ; \mathrm{M}\right)$, total nitrogen $(\mathrm{TN} ; \mathrm{M})$, dissolved inorganic nitrogen (DIN; M), total organic nitrogen (TON; M), dissolved oxygen (DO), phytoplankton chlorophyll $a$ (Chl $a ; \mathrm{g}$ ), total organic carbon (TOC; M), soluble reactive phosphorus (SRP; M), and total phosphorus (TP; M).

\begin{tabular}{|c|c|c|c|c|c|c|}
\hline Site & Bob Allen & Duck Key & Little Madiera & Sprigger Bank & Trout Cove & P-value \\
\hline Thalassia testudinm & $1.83 \pm 0.16$ & $1.93 \pm 0.08$ & $3.45 \pm 0.48$ & $2.73 \pm 0.15$ & 0 & $<0.001$ \\
\hline Syringodium filiforme & 0 & 0 & 0 & $2.85 \pm 0.09$ & 0 & na \\
\hline Halodule wrightii & 0 & 0 & $0.76 \pm 0.25$ & 0 & $2.25 \pm 0.16$ & na \\
\hline Halimeda spp. & 0 & 0 & $0.004 \pm 0.004$ & $1.23 \pm 0.24$ & 0 & na \\
\hline Penicillus spp. & $0.20 \pm 0.11$ & $0.46 \pm 0.09$ & $0.02 \pm 0.02$ & $0.98 \pm 0.40$ & 0 & 0.014 \\
\hline Batophora spp. & $0.67 \pm 0.49$ & $0.48 \pm 0.24$ & $0.02 \pm 0.01$ & 0 & 0 & na \\
\hline Laurencia spp. & $0.003 \pm 0.002$ & $0.253 \pm 0.149$ & $0.001 \pm 0.001$ & 0 & $0.013 \pm 0.011$ & na \\
\hline Sponge & $0.0550 \pm 0.0148$ & $0.0275 \pm 0.0217$ & $0.0004 \pm 0.0004$ & $0.0925 \pm 0.0360$ & 0 & na \\
\hline CGT & $0.35 \pm 0.09$ & $0.45 \pm 0.09$ & $0.03 \pm 0.02$ & $1.56 \pm 0.41$ & $0.05 \pm 0.04$ & $<0.001$ \\
\hline Depth & $5.00 \pm 0.36$ & $6.50 \pm 0.57$ & $2.0 \pm 00$ & $3.25 \pm 0.22$ & $2.00 \pm 0.37$ & $<0.001$ \\
\hline Turbidity & $0.81 \pm 0.19$ & $0.91 \pm 0.15$ & $1.07 \pm 0.25$ & $0.27 \pm 0.06$ & $1.13 \pm 0.28$ & 0.055 \\
\hline $\operatorname{Temp}\left({ }^{\circ} \mathrm{C}\right)$ & $27.65 \pm 2.01$ & $28.18 \pm 1.79$ & $29.19 \pm 1.75$ & $26.86 \pm 2.24$ & $30.58 \pm 1.74$ & 0.768 \\
\hline Salinity & $37.31 \pm 2.64$ & $33.36 \pm 1.89$ & $27.36 \pm 1.55$ & $35.77 \pm 1.44$ & $25.19 \pm 1.13$ & 0.002 \\
\hline Seagrass leaf $\mathrm{N}$ & $2.62 \pm 0.10$ & $2.30 \pm 0.03$ & $2.26 \pm 0.08$ & $1.91 \pm 0.10$ & $2.44 \pm 0.03$ & 0.005 \\
\hline Seagrass leaf C & $39.20 \pm 0.09$ & $38.52 \pm 0.96$ & $38.79 \pm 0.62$ & $38.67 \pm 0.65$ & $39.12 \pm 0.38$ & 0.938 \\
\hline Seagrass leaf $P$ & $0.049 \pm 0.002$ & $0.047 \pm 0.003$ & $0.055 \pm 0.004$ & $0.118 \pm 0.007$ & $0.078 \pm 0.008$ & $<0.001$ \\
\hline Epiphyte biomass & $0.0088 \pm 0.0006$ & $0.0097 \pm 0.0008$ & $0.0104 \pm 0.0012$ & $0.0087 \pm 0.0003$ & $0.0010 \pm 0.0013$ & 0.735 \\
\hline Dry weight & $0.67 \pm 0.05$ & $0.39 \pm 0.11$ & $1.09 \pm 0.09$ & $3.75 \pm 0.25$ & $1.54 \pm 0.05$ & $<0.001$ \\
\hline Inorganic matter & $0.19 \pm 0.03$ & $0.08 \pm 0.03$ & $0.20 \pm 0.02$ & $0.89 \pm 0.16$ & $0.58 \pm 0.04$ & $<0.001$ \\
\hline Organic matter & $0.48 \pm 0.06$ & $0.26 \pm 0.09$ & $0.88 \pm 0.07$ & $2.86 \pm 0.24$ & $0.96 \pm 0.09$ & $<0.001$ \\
\hline $\mathrm{NO}_{\mathrm{x}}$ & $0.62 \pm 0.05$ & $2.56 \pm 0.32$ & $1.04 \pm 0.11$ & $0.20 \pm 0.01$ & $2.01 \pm 0.09$ & $<0.001$ \\
\hline $\mathrm{NO}_{3}^{-}$ & $0.47 \pm 0.04$ & $2.14 \pm 0.27$ & $0.82 \pm 0.10$ & $0.17 \pm 0.01$ & $1.68 \pm 0.07$ & $<0.001$ \\
\hline $\mathrm{NO}_{2}^{-}$ & $.0159 \pm 0.016$ & $0.424 \pm 0.069$ & $0.227 \pm 0.019$ & $0.060 \pm 0.003$ & $0.331 \pm 0.029$ & $<0.001$ \\
\hline $\mathrm{NH}_{4}^{+}$ & $4.15 \pm 0.51$ & $4.67 \pm 0.55$ & $4.80 \pm 0.90$ & $0.359 \pm 0.02$ & $4.93 \pm 1.01$ & $<0.001$ \\
\hline TN & $33.43 \pm 1.41$ & $33.08 \pm 0.26$ & $35.43 \pm 0.99$ & $18.81 \pm 0.68$ & $35.26 \pm 1.84$ & $<0.001$ \\
\hline DIN & $4.78 \pm 0.53$ & $7.23 \pm 0.69$ & $5.84 \pm 0.98$ & $0.56 \pm 0.02$ & $6.94 \pm 1.04$ & $<0.001$ \\
\hline TON & $29.66 \pm 1.78$ & $25.85 \pm 0.67$ & $29.59 \pm 1.17$ & $18.24 \pm 0.70$ & $28.32 \pm 1.34$ & $<0.001$ \\
\hline DO & $6.50 \pm 0.30$ & $6.70 \pm 0.31$ & $6.87 \pm 0.36$ & $6.74 \pm 0.24$ & $6.89 \pm 0.38$ & 0.943 \\
\hline Phytoplankton $\mathrm{Chl} a$ & $0.54 \pm 0.05$ & $0.36 \pm 0.09$ & $0.46 \pm 0.10$ & $0.77 \pm 0.08$ & $0.98 \pm 0.11$ & 0.003 \\
\hline TOC & $693.85 \pm 10.92$ & $591.40 \pm 12.30$ & $783.43 \pm 13.59$ & $301.62 \pm 26.39$ & $801.66 \pm 21.23$ & $<0.001$ \\
\hline SRP & $0.049 \pm 0.004$ & $0.054 \pm 0.005$ & $0.072 \pm 0.008$ & $0.039 \pm 0.001$ & $0.065 \pm 0.003$ & 0.005 \\
\hline IP & $0.234 \pm 0.013$ & $0.256 \pm 0.016$ & $0.265 \pm 0.020$ & $0.435 \pm 0.059$ & $0.306 \pm 0.007$ & 0.004 \\
\hline
\end{tabular}


Table 3.3. Standardized principle component factor loadings after varimax rotation. Variables loading strongly on each component are in bold text. Units of measure listed here in parentheses. Thalassia testudinum (BB score), Syringodium filiforme (BB score), Halodule wrightii (BB score), Halimeda spp. (BB score), Penicillus spp. (BB score), Batophora spp. (BB score), Laurencia spp. (BB score), sponge (BB score), CGT (BB score), Date (as sampling month), Depth (ft), Turbidity (NTU), Temperature $\left({ }^{\circ} \mathrm{C}\right)$, Salinity (PSU), N (\%), C (\%), P (\%), Epiphyte biomass (chl $a$ per seagrass short shoot), Dry Weight (DW in g of seagrass biomass collected with amphipods), Inorganic matter (weight in $\mathrm{g}$ of ashes from combusted DW), and Organic matter (weight in $\mathrm{g}$, ash-free dry weight), nitrate+nitrite (NOX; M), nitrate $\left(\mathrm{NO}_{3}^{-} ; \mathrm{M}\right)$, nitrite $\left(\mathrm{NO}_{2}^{-} ; \mathrm{M}\right)$, ammonium $\left(\mathrm{NH}_{4}{ }^{+} ; \mathrm{M}\right)$, total nitrogen (TN; M), dissolved inorganic nitrogen (DIN; M), total organic nitrogen (TON; M), dissolved oxygen (DO), water-column chlorophyll $a$ (Chl $a ; \mathrm{g}$ ), total organic carbon (TOC; M), soluble reactive phosphorus (SRP; M), and total phosphorus (TP; M).

\begin{tabular}{|c|c|c|c|c|}
\hline & $\begin{array}{c}\text { PC1 } \\
\begin{array}{c}\text { Macrophyte } \\
\text { density }\end{array} \\
\end{array}$ & $\begin{array}{c}\text { PC2 } \\
\text { Nitrogen } \\
\text { concentration }\end{array}$ & $\begin{array}{c}\text { PC3 } \\
\text { Freshwater } \\
\text { input }\end{array}$ & $\begin{array}{c}\text { PC4 } \\
\text { Seasonality }\end{array}$ \\
\hline Variation explained (\%) & 37 & 13 & 12 & 11 \\
\hline Thalassia testudimum & 0.10 & -0.32 & -0.50 & -0.15 \\
\hline Syringodium filiforme & 0.91 & -0.33 & 0.06 & -0.07 \\
\hline Halodule wrightii & -0.35 & 0.12 & 0.85 & 0.00 \\
\hline Halimeda spp. & 0.92 & -0.23 & 0.08 & 0.14 \\
\hline Penicillus spp. & 0.77 & 0.06 & -0.19 & 0.40 \\
\hline CGT & 0.87 & -0.09 & -0.13 & 0.35 \\
\hline Batophora spp. & -0.14 & 0.07 & -0.47 & 0.38 \\
\hline Laurencia spp. & 0.00 & 0.47 & -0.31 & 0.13 \\
\hline Sponge & 0.64 & -0.09 & -0.25 & 0.24 \\
\hline Date & 0.06 & 0.08 & 0.05 & 0.90 \\
\hline Depth & 0.06 & 0.38 & -0.80 & 0.26 \\
\hline Temperature & -0.13 & 0.14 & 0.24 & 0.83 \\
\hline Salinity & 0.39 & -0.18 & -0.60 & 0.61 \\
\hline Turbidity & -0.61 & 0.13 & 0.23 & 0.01 \\
\hline $\mathrm{C}$ & -0.22 & -0.29 & 0.05 & 0.28 \\
\hline $\mathrm{N}$ & -0.76 & 0.04 & -0.02 & 0.04 \\
\hline $\mathrm{P}$ & 0.80 & -0.20 & 0.45 & 0.07 \\
\hline Epiphyte biomass & -0.08 & 0.14 & 0.03 & -0.24 \\
\hline Macrophyte dry weight & 0.84 & -0.36 & 0.37 & 0.03 \\
\hline Inorganic Matter & 0.71 & -0.22 & 0.54 & 0.26 \\
\hline Organic Matter & 0.83 & -0.38 & 0.28 & -0.05 \\
\hline $\mathrm{NO}_{\mathrm{X}}$ & -0.35 & 0.89 & 0.09 & -0.13 \\
\hline $\mathrm{NO}_{2}^{-}$ & -0.40 & 0.87 & 0.04 & -0.19 \\
\hline $\mathrm{NO}_{3}{ }^{-}$ & -0.33 & 0.89 & 0.09 & -0.12 \\
\hline $\mathrm{NH}_{4}^{+}$ & -0.73 & 0.43 & 0.05 & 0.20 \\
\hline TN & -0.95 & 0.18 & 0.03 & 0.15 \\
\hline TON & -0.92 & -0.12 & 0.00 & 0.15 \\
\hline DIN & -0.69 & 0.63 & 0.07 & 0.12 \\
\hline SRP & -0.56 & 0.22 & 0.30 & -0.11 \\
\hline TP & 0.60 & -0.21 & 0.28 & -0.29 \\
\hline TOC & -0.93 & 0.09 & 0.27 & 0.06 \\
\hline DO & 0.05 & 0.15 & 0.17 & -0.84 \\
\hline Phytoplankton (chl $a$ ) & 0.30 & -0.01 & 0.74 & 0.19 \\
\hline
\end{tabular}




\section{Figure Legends}

Figure 3.1. Map of the study sites in Florida Bay. The five sites sampled were Trout Cove (TC), Duck Key (DK), Little Madiera (LM), Bob Allen Keys (BA), and Sprigger Bank (SB).

Figure 3.2. Shade plot of amphipod density by site and season. Each cell is shaded to correspond to the density of the species at that date and time. Darker grey cells indicate a higher density and lighter cells indicate lower density.

Figure 3.3. Box plots of amphipod density per $\mathrm{m}^{2}$ (a-d), species richness (e-h), ShannonWiener diversity index (i-1), and inverse Simpson's dominance index (m-p) by site (BA=Bob Allen, DK=Duck Key, LM=Little Madiera, SB=Sprigger Bank, and TC=Trout Cove) and season (rows).

Figure 3.4. Nonmultidimensional scaling plot of amphipod community for each site and season. Bob Allen (BA, triangles), Duck Key (DK, asterisks), Little Madiera (LM, inverted triangles), Trout Cove (TC, x's), and Sprigger Bank (SB, circles). Months are designated by shading of symbols where the darkest symbols are for January samples and the lightest samples are for October sampling.

Figure 3.5. Dendrogram of cluster analysis of the amphipod community data across sites and seasons. Dark circles at nodes indicate significantly different clusters. Non-dashed lines indicate divisions not supported at the $\mathrm{p}<0.05$ significance level.

Figure 3.6. Biplots of first and third principle components explaining $49 \%$ of the variation in environmental data. Macrophyte density (PC1) explains $37 \%$ of the variation. Freshwater input (PC3) explains $12 \%$ of the variation. Bob Allen (BA, triangles), Duck Key (DK, asterisks), Little Madiera (LM, inverted triangles), Trout Cove (TC, x's), and Sprigger Bank (SB, circles). Months are designated by shading of symbols where the darkest symbols are for January samples and the lightest samples are for October sampling.

Figure 3.7. dbRDA ordination plot of the best fit model (from the DISTLM procedure) of multivariate amphipod community data as explained by the environmental components from the five Florida Bay sites in for seasons. 


\section{Figures}

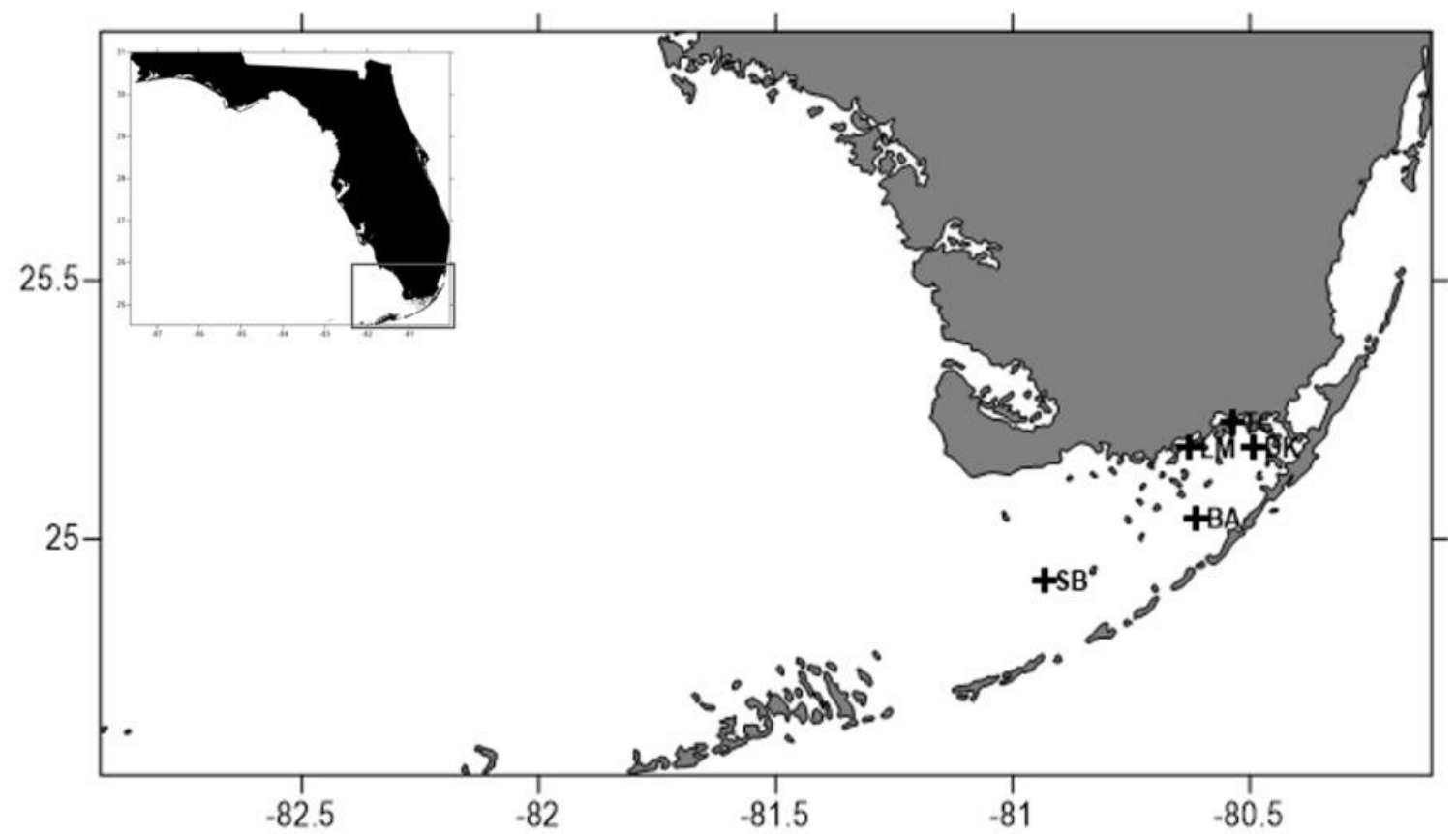

Figure 3.1. Map of the study sites in Florida Bay. The five sites sampled were Trout Cove (TC), Duck Key (DK), Little Madiera (LM), Bob Allen Keys (BA), and Sprigger Bank (SB). 


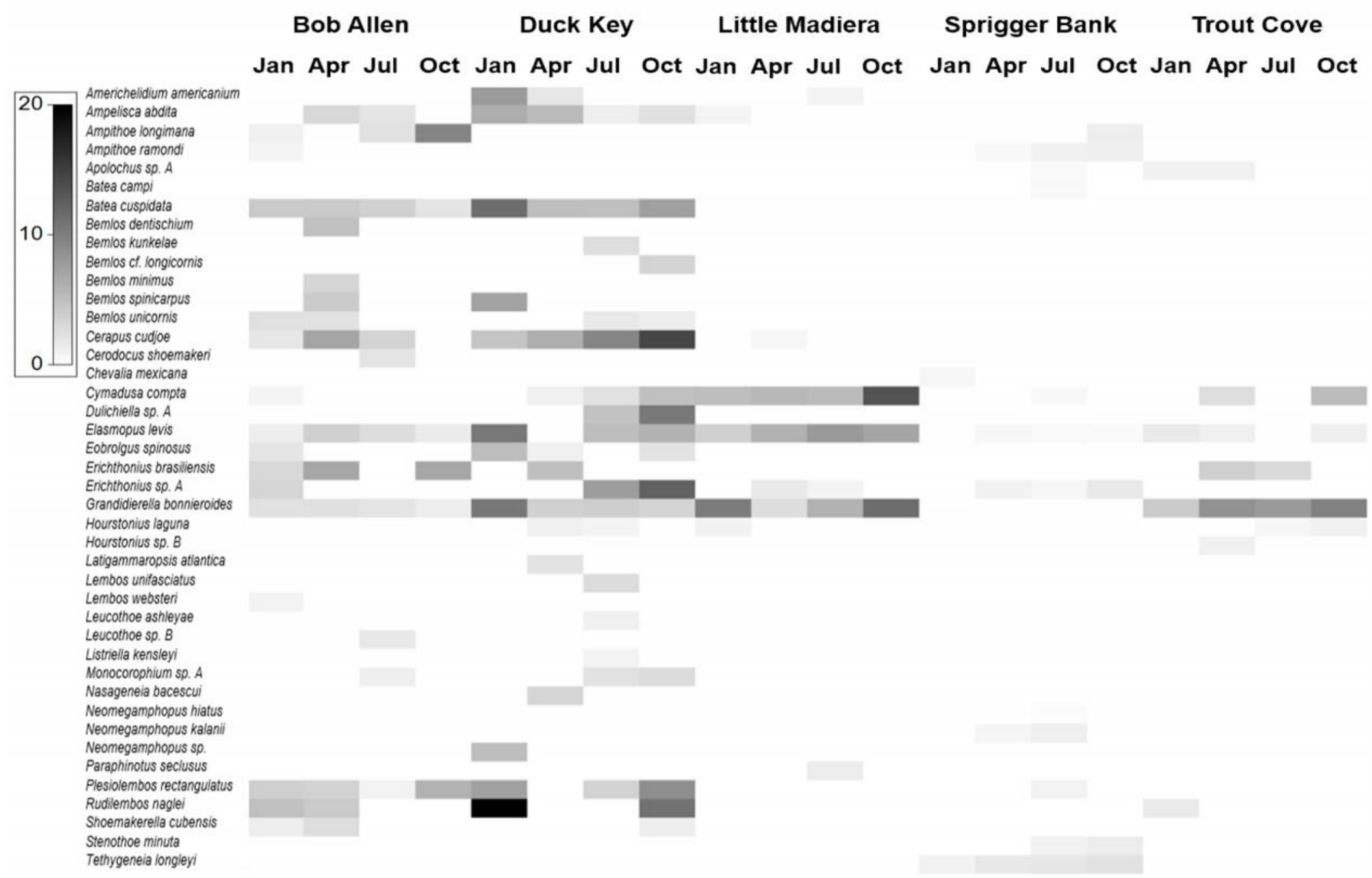

Figure 3.2. Shade plot of amphipod density by site and season. Each cell is shaded to correspond to the density of the species at that date and time. Darker grey cells indicate a higher density and lighter cells indicate lower density. 

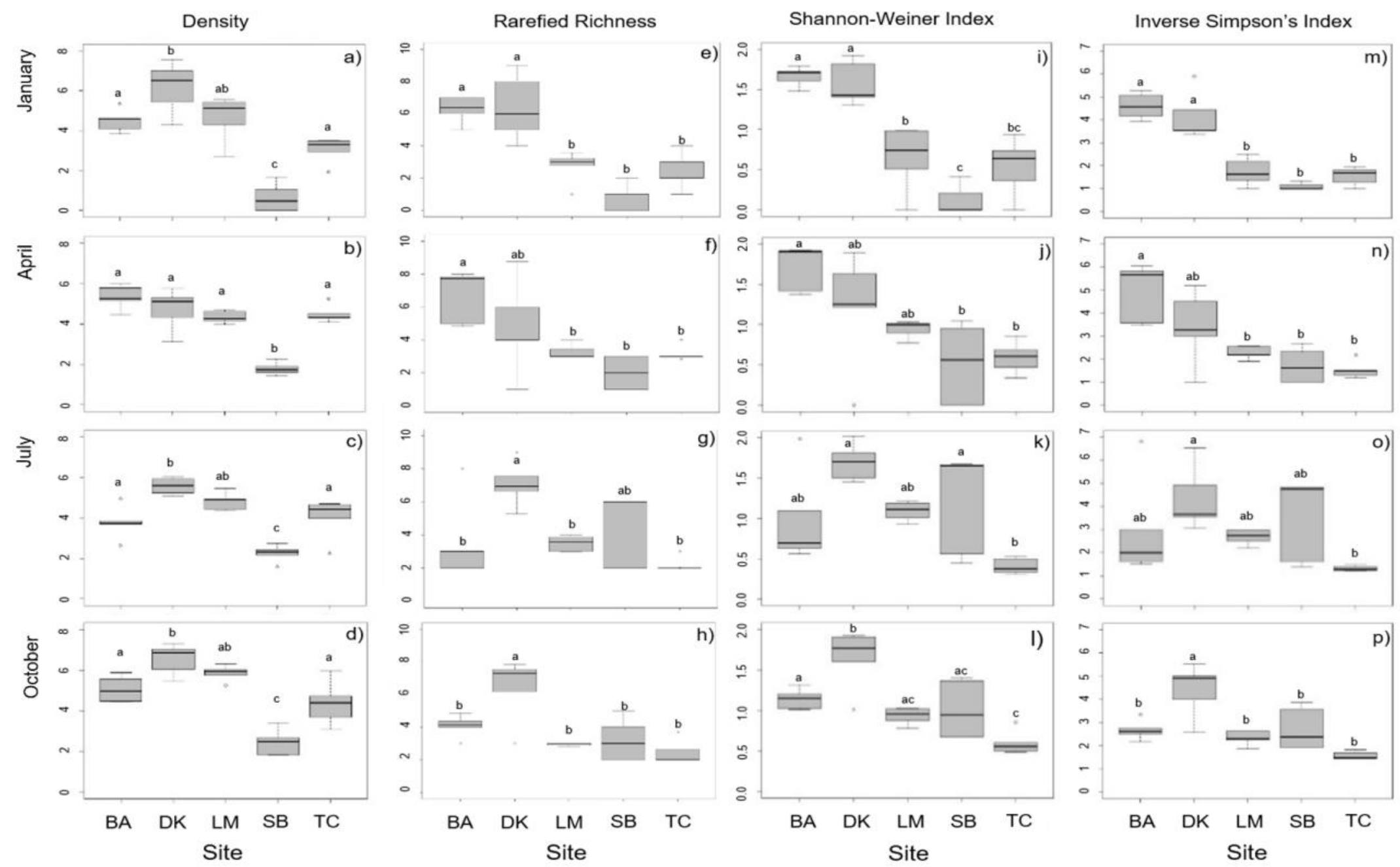

Figure 3.3. Box plots of amphipod density per $\mathrm{m}^{2}$ (a-d), species richness (e-h), Shannon-Wiener diversity index (i-l), and inverse Simpson's dominance index (m-p) by site (BA=Bob Allen, DK=Duck Key, LM=Little Madiera, SB=Sprigger Bank, and $\mathrm{TC}=$ Trout Cove) and season (rows). 


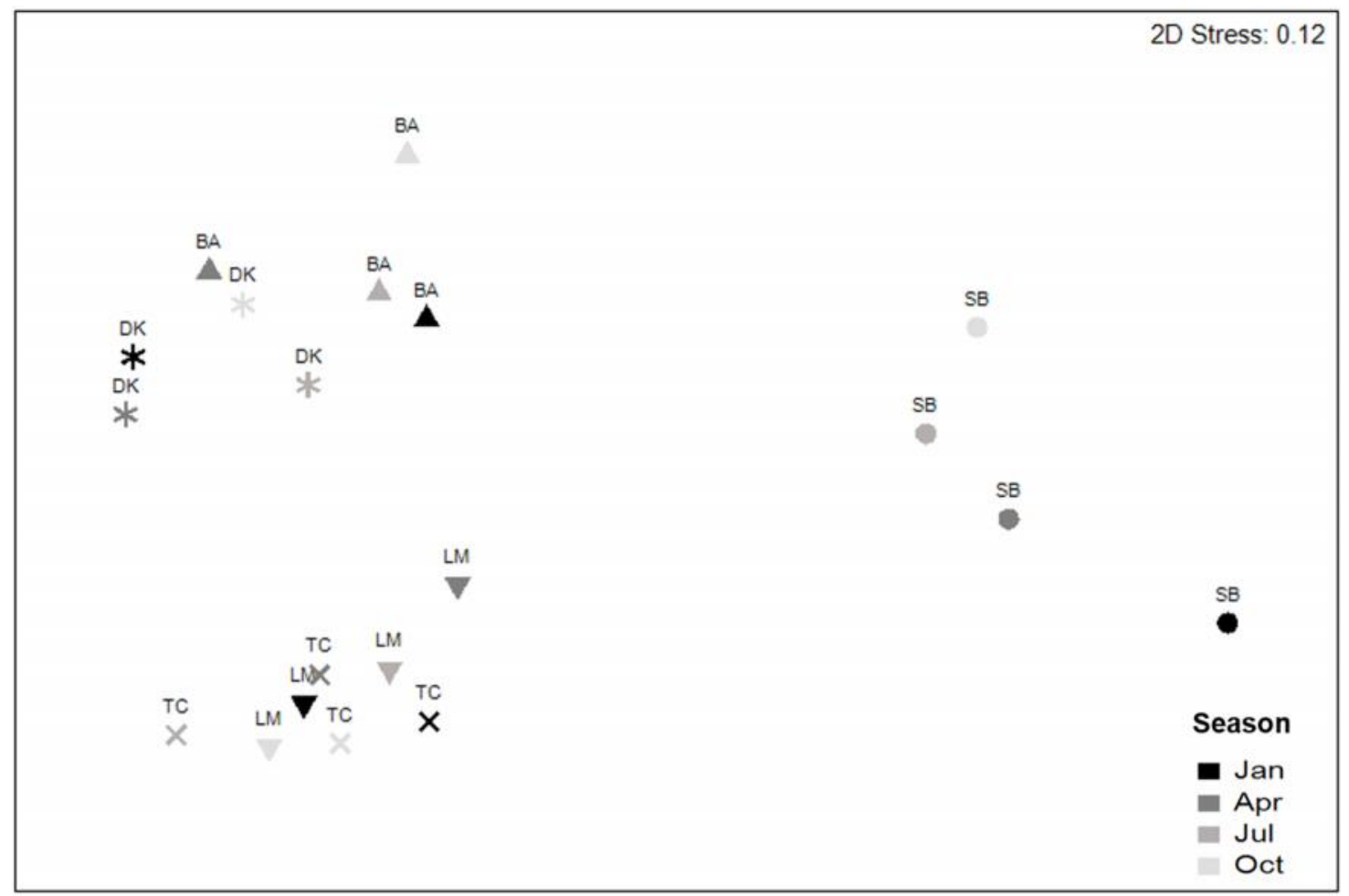

Figure 3.4. Nonmultidimensional scaling plot of amphipod community for each site and season. Bob Allen (BA, triangles), Duck Key (DK, asterisks), Little Madiera (LM, inverted triangles), Trout Cove (TC, x's), and Sprigger Bank (SB, circles). Months are designated by shading of symbols where the darkest symbols are for January samples and the lightest samples are for October sampling. 


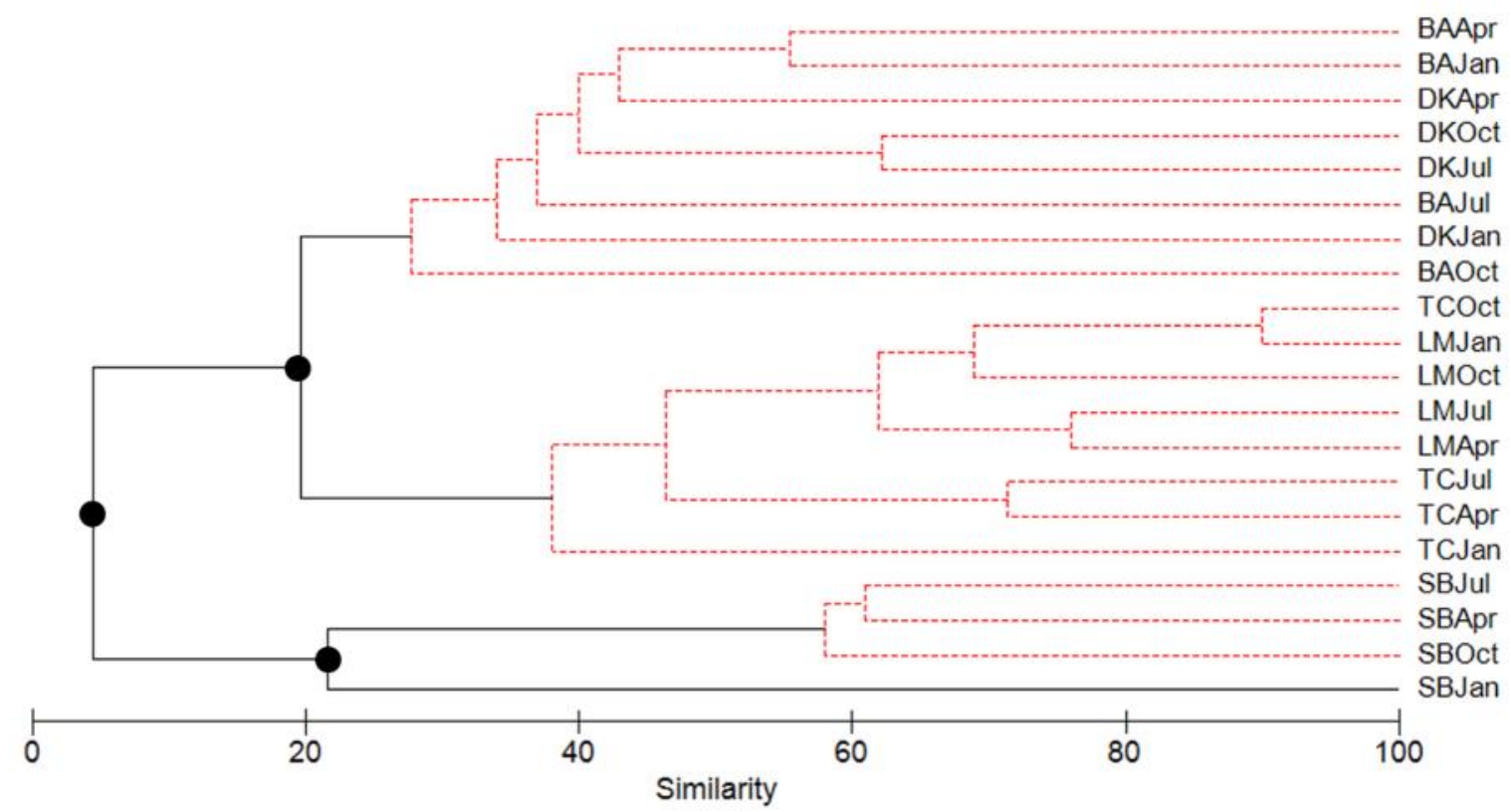

Figure 3.5. Dendrogram of cluster analysis of the amphipod community data across sites and seasons. Dark circles at nodes indicate significantly different clusters. Non-dashed lines indicate divisions not supported at the $\mathrm{p}<0.05$ significance level. 


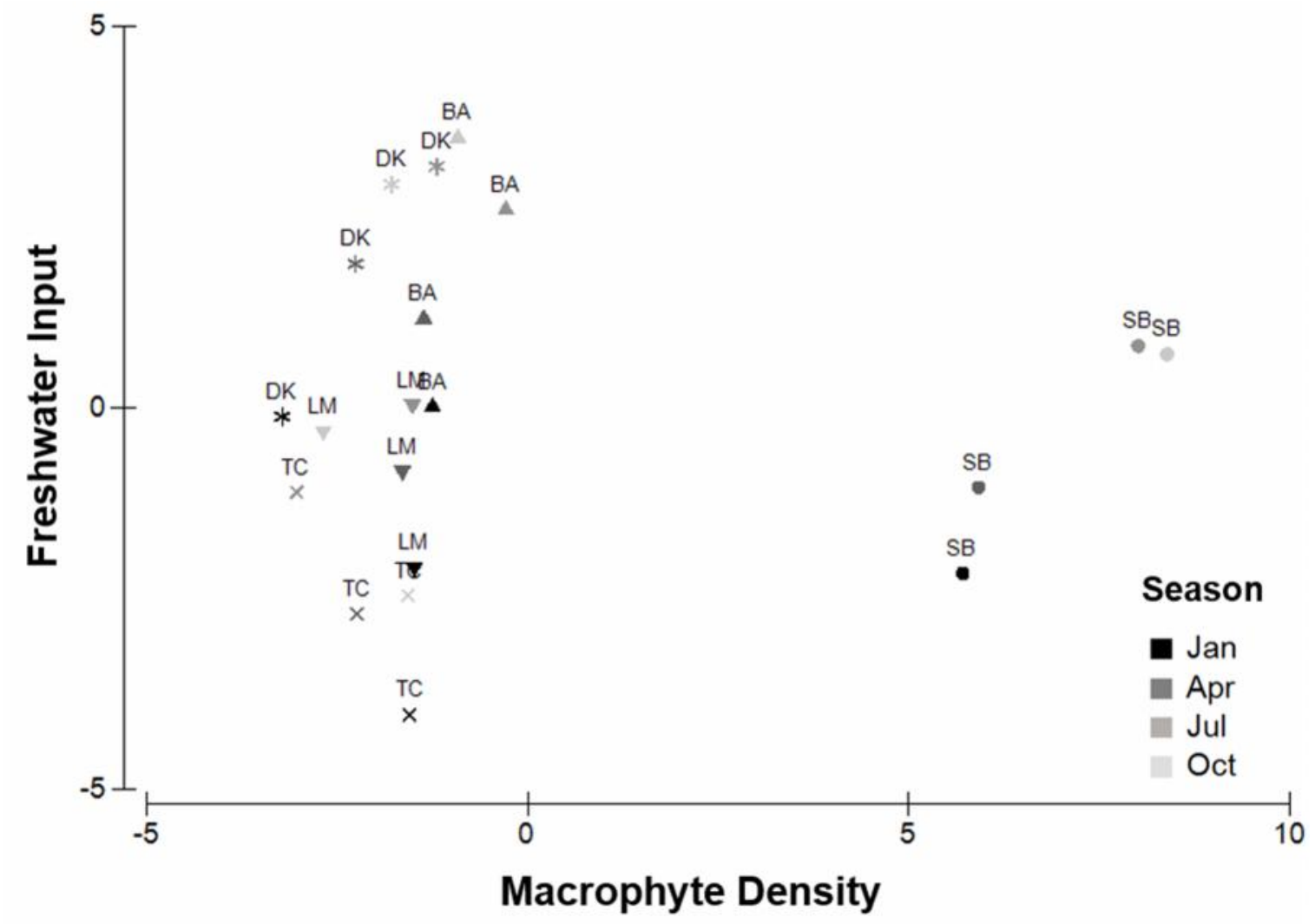

Figure 3.6. Biplots of first and third principle components explaining $49 \%$ of the variation in environmental data. Macrophyte density (PC1) explains 37\% of the variation. Freshwater input (PC3) explains $12 \%$ of the variation. Bob Allen (BA, triangles), Duck Key (DK, asterisks), Little Madiera (LM, inverted triangles), Trout Cove (TC, x's), and Sprigger Bank (SB, circles). Months are designated by shading of symbols where the darkest symbols are for January samples and the lightest samples are for October sampling. 


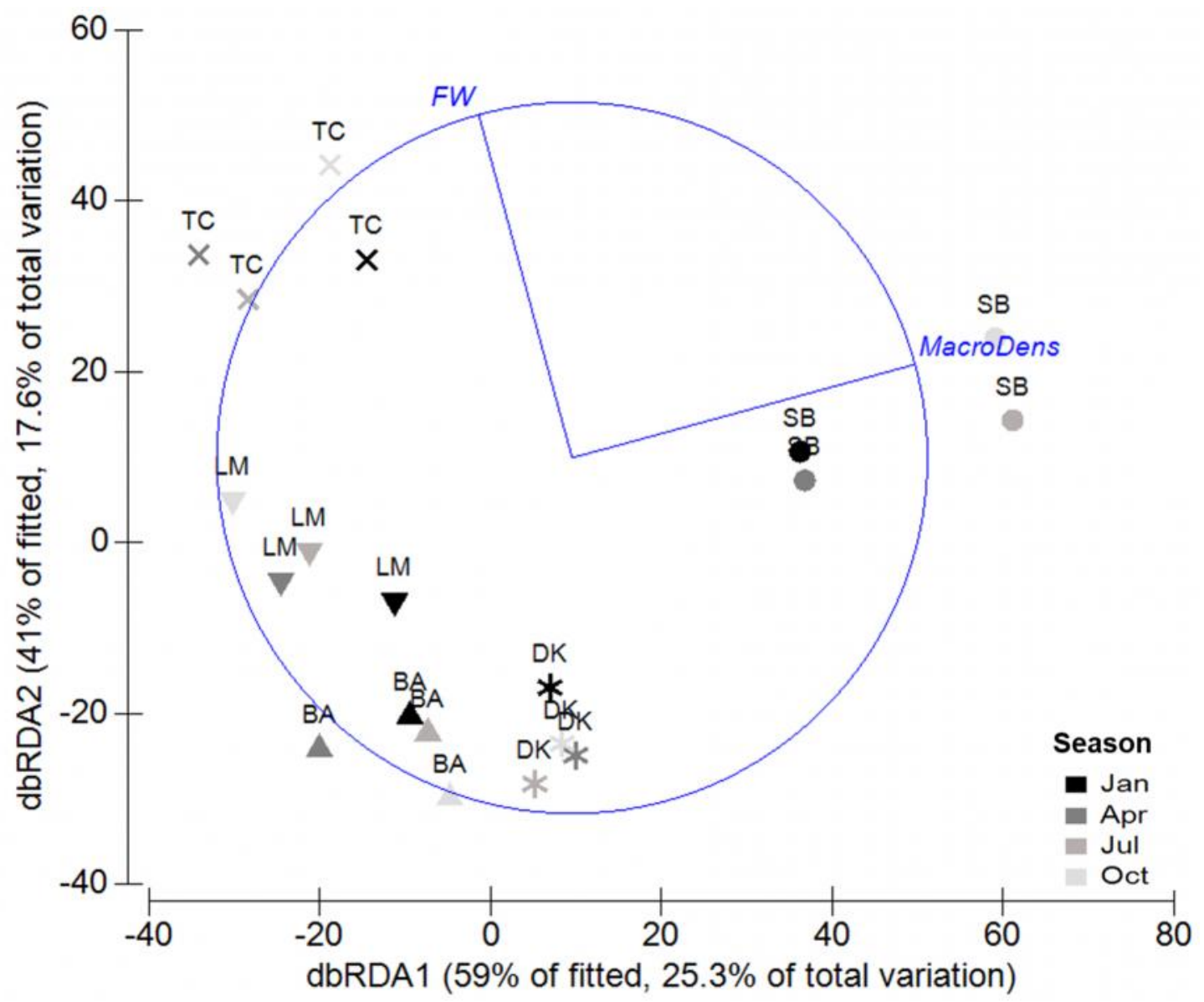

Figure 3.7. dbRDA ordination plot of the best fit model (from the DISTLM procedure) of multivariate amphipod community data as explained by the environmental components from the five Florida Bay sites in for seasons. 


\section{References}

Altermatt, F., Alther, R., Fišer, C., Jokela, J., Konec, M., Küry, D., Mächler, E., Stucki, P., Westram, A.M., 2014. Diversity and distribution of freshwater amphipod species in Switzerland (Crustacea: Amphipoda). PLoS One 9, e110328.

doi:10.1371/journal.pone.0110328

Barnard, J.L., Sandved, K., Thomas, J.D., 1991. Tube-building behavior in Grandidierella, and two species of Cerapus. Hydrobiologia 223, 239-254. doi:10.1007/BF00047643

Bousfield, E.L., 1973. Shallow-Water Gammaridean Amphipoda of New England. Cornell University Press.

Boyer, J.N., Fourqurean, J.W., Jones, R.D., 1999. Seasonal and long-term trends in the water quality of Florida Bay. Estuaries 22, 417-430.

Boyer, J.N., Fourqurean, J.W., Jones, R.D., 1997. Spatial characterization of water quality in Florida Bay and Whitewater Bay by multivariate analyses: Zones of similar influence. Estuaries 20, 743-758.

Boyer, J.N., Jones, R.D., 2002. An integrated surface water quality monitoring program for the south Florida coastal waters. Miami.

Brook, I.M., 1977. Trophic relationships in a seagrass community (Thalassia testudinum), in Card Sound, Florida. Fish diets in relation to macrobenthic and cryptic faunal abundance. Trans. Am. Fish. Soc. 106, 219-229. doi:10.1577/15488659(1977) $106<219:$ TRIASC >2.0.CO;2

Burnham, K., Anderson, D., 2002. Model Selection and Multimodel Inference: A Practical Information-theoretic Approach, second ed. Springer, New York.

Burkholder, J.M., Tomasko, D. a., Touchette, B.W., 2007. Seagrasses and eutrophication. J. Exp. Mar. Bio. Ecol. 350, 46-72. doi:10.1016/j.jembe.2007.06.024

Clarke, K.R., 1993. Non-parametric multivariate analyses of changes in community structure. Austral Ecol. 18, 117-143. doi:10.1111/j.1442-9993.1993.tb00438.x

Clarke, K.R., Gorley, R.N., Somerfield, P.J., Warwick, R.M., 2014. Change in marine communities: an approach to statistical analysis and interpretation, 3rd edition. Plymouth. 
Collado-Vides, L., Avila, C., Blair, S., Leliaert, F., Rodriguez, D., Thyberg, T., Schneider, S., Rojas, J., Sweeney, P., Drury, C., Lirman, D., 2013. A persistent bloom of Anadyomene J.V. Lamouroux (Anadyomenaceae, Chlorophyta) in Biscayne Bay, Florida. Aquat. Bot. 111, 95-103. doi:10.1016/j.aquabot.2013.06.010

Craft, C., Krull, K., Graham, S., 2007. Ecological indicators of nutrient enrichment, freshwater wetlands, Midwestern United States (U.S.). Ecol. Indic. 7, 733-750. doi:10.1016/j.ecolind.2006.08.004

Craft, C.B., Richardson, C.J., 1997. Relationships between soil nutrients and plant species composition in Everglades peatlands. J. Environ. Qual. 26, 224. doi:10.2134/jeq1997.00472425002600010032x

Cruz-Rivera, E., Hay, M.E., 2000. Can quantity replace quality? Food choice, compensatory feeding, and fitness of marine mesograzers. Ecology 81, 201-219. doi:10.1890/0012-9658(2000)081[0201:CQRQFC]2.0.CO;2

Dahl, E., 1948. On the smaller Arthropoda of marine algae, especially in the polyhaline waters off the Swedish west coast. Undersokningar over Oresund 35, 5-148.

de-la-Ossa-Carretero, J.A., Del-Pilar-Ruso, Y., Giménez-Casalduero, F., Sánchez-Lizaso, J.L., Dauvin, J.-C., 2012. Sensitivity of amphipods to sewage pollution. Estuar. Coast. Shelf Sci. 96, 129-138. doi:10.1016/j.ecss.2011.10.020

Douglass, J.G., Duffy, J.E., Bruno, J.F., 2008. Herbivore and predator diversity interactively affect ecosystem properties in an experimental marine community. Ecol. Lett. 11, 598-608. doi:10.1111/j.1461-0248.2008.01175.x

Douglass, J.G., France, K.E., Paul Richardson, J., Duffy, J.E., 2010. Seasonal and interannual change in a Chesapeake Bay eelgrass community: Insights into biotic and abiotic control of community structure. Limnol. Oceanogr. 55, 1499-1520. doi:10.4319/lo.2010.55.4.1499

Duarte, C., Navarro, J.M., Acuña, K., Gómez, I., 2010. Feeding preferences of the sandhopper Orchestoidea tuberculata: the importance of algal traits. Hydrobiologia 651, 291-303. doi:10.1007/s10750-010-0309-5

Duever, M.J., Meeder, J.F., Meeder, L.C., McCollom, J.M., 1994. The climate of South Florida and its role in shaping the Everglades ecosystem, in: Everglades: The Ecosystem and Its Restoration. St. Lucie Press, Boca Raton, Florida, USA, pp. 225248.

Duffy, J.E., Hay, M.E., 2000. Strong impacts of grazing amphipods on the organization of a benthic community. Ecol. Modell. 70, 237-263. 
Englert, D., Zubrod, J.P., Schulz, R., Bundschuh, M., 2013. Effects of municipal wastewater on aquatic ecosystem structure and function in the receiving stream. Sci. Total Environ. 454-455, 401-10. doi:10.1016/j.scitotenv.2013.03.025

Fourqurean, J.W., Jones, R.D., Zieman, J.C., 1993. Process Influencing Water Column Nutrient Characteristics and Phosphorus Limitation of Phytoplankton Biomass in Florida Bay, FL, USA:Inferences from Spatial Distributions. Estuar. Coast. Shelf Sci. 36, 295-314. doi:10.1006/ecss.1993.1018

Fourqurean, J.W., Robblee, M.B., 1999. Florida Bay: A history of recent ecological changes. Estuaries 22, 345. doi:10.2307/1353203

Fourqurean, J.W., Rutten, L.M., 2003. Competing goals of spatial and temporal resolution: Monitoring seagrass communities on a regional scale, in: Busch, D.E., Trexler, J.C. (Eds.), Monitoring Ecosystem Initiatives: Interdisciplinary Approaches for Evaluating Ecoregional Initiatives. Island Press, Washington, D.C., pp. 257-288.

Fourqurean, J.W., Willsie, A., Rose, C.D., Rutten, L.M., 2001. Spatial and temporal pattern in seagrass community composition and productivity in south Florida. Mar. Biol. 138, 341-354. doi:10.1007/s002270000448

Fourqurean, J.W., Zieman, J.C., 1992. Phosphorus limitation of primary production in Florida Bay: Evidence from C:N:P ratios of the dominant seagrass Thalassia testudinum. Limnol. Oceanogr. 37, 162-171.

Frankovich, T.A., Fourqurean, J.W., 1997. Seagrass epiphyte loads along a nutrient availability gradient, Florida Bay, USA. Mar. Ecol. Prog. Ser. 159, 37-50.

Gesteira, J.L.G., Dauvin, J.-C., 2000. Amphipods are good bioindicators of the impact of oil spills on soft-bottom macrobenthic communities. Mar. Pollut. Bull. 40, 10171027. doi:10.1016/S0025-326X(00)00046-1

Gotelli, N.J., Colwell, R.K., 2001. Quantifying biodiversity: procedures and pitfalls in the measurement and comparison of species richness. Ecol. Lett. 4, 379-391. doi:10.1046/j.1461-0248.2001.00230.x

Guerra-García, J.M., Koonjul, M.S., 2005. Metaprotella sandalensis (Crustacea: Amphipoda: Caprellidae): A bioindicator of nutrient enrichment on coral reefs? Environ. Monit. Assess. 104, 353-367. doi:10.1007/s10661-005-1621-9

Harrell FE, with contributions from Charles Dupont and many others. 2016. Hmisc: Harrell Miscellaneous. R package version 3.17-2. http://CRAN.Rproject.org/package $=$ Hmisc 
Heard, R.W., 1982. Guide to common tidal marsh invertebrates of the northeastern Gulf of Mexico.

Heck, K.L., Orth, R.J., 1980. Seagrass habitats: the roles of habitat complexity, competition and predation in structuring associated fish and motile macroinvertebrate assemblages, in: Kennedy, V.S. (Ed.), Estuarine Perspectives. Academic Press, New York, pp. 449-464.

Heck, K.L., Wetstone, G.S., 1977. Habitat complexity and invertebrate species richness and abundance in tropical seagrass meadows. J. Biogeogr. 4, 135-142.

Hein, M., Pedersen, M.F., Sand-Jensen, K., 1995. Size-dependent nitrogen uptake in micro- and macroalgae. Mar. Ecol. Prog. Ser. 118, 247-253.

Holloway, J.D., Stork, N.E., 1991. The dimensions of biodiversity: the use of invertebrates as indicators of human impact, in: Hawksworth, D.L. (Ed.), The Biodiversity of Micro-Organisms and Invertebrates: Its Role in Sustainable Agriculture. CAB International, London, pp. 37-61.

Holmquist, J.G., 1994. Benthic macroalgae as a dispersal mechanism for fauna: influence of a marine tumbleweed. J. Exp. Mar. Bio. Ecol. 180, 235-251. doi:10.1016/00220981(94)90069-8

Howard, J.L., Perez, A., Lopes, C.C., Fourqurean, J.W., 2016. Fertilization changes seagrass community structure but not blue carbon storage: Results from a 30-year field experiment. Estuaries and Coasts. doi:10.1007/s12237-016-0085-1

Jensen, J.R., Koch, M.S., Narumalani, S., 1995. Inland wetland changes detection in the Everglades water conservation area $2 \mathrm{~A}$ using a time series of normalized remotely sensed data. Photogramm. Eng. Remote Sensing 61, 199-209.

Jimenez, E.G., Hauxwell, J., Heckscher, E., Rietsma, C., Valiela, I., 1996. Selection of nitrogen-enriched macroalgae (Cladophora vagabunda and Gracilaria tikvahiae by the herbivorous amphipod Microdeutopus gryllotalpa. Biol. Bull. 191, 323-324.

Lecroy, S.E., 2002. An illustrated identification guide to the nearshore marine and estuarine gammaridean amphipoda of Florida. Tallahassee.

Lewis, F.G., Stoner, A.W., 1983. Distribution of macrofauna within seagrass beds: an explanation for patterns and abundance. Bull. Mar. Sci. 33, 296-304.

McClelland, J.W., Valiela, I., 1998. Linking nitrogen in estuarine producers to landderived sources. Limnol. Oceanogr. 43, 577-585. 
McGeoch, M.A., 2007. The selection, testing and application of terrestrial insects as bioindicators. Biol. Rev. 73, 181-201. doi:10.1111/j.1469-185X.1997.tb00029.x

McIvor, C.C., Ley, J.A., Bjork, R.D., 1994. Changes in freshwater inflow from the Everglades to Florida Bay including effects on biota and biotic processes: A review, in: Davis, S.M., Ogden, J.C. (Eds.), Everglades: The Ecosystem and Its Restoration. St. Lucie Press, Delray Beach, Florida, pp. 117-148.

National Research Council 2002 Florida bay research programs and their relation to the comprehensive everglades restoration. National academy press, 42pp

Nelson, G.A., 1998. Abundance, growth, and mortality of young-of-the-year pinfish, Lagodon rhomboides, in three estuaries along the gulf coast of Florida. Fish. Bull. 96, 315-328.

Nelson, W.G., 1979a. An analysis of structural pattern in an eelgrass (Zostera marina L.) amphipod community. J. Exp. Mar. Bio. Ecol. 39, 231-264. doi:10.1016/00220981(79)90129-1

Nelson, W.G., 1979b. Experimental studies of selective predation on ampibpods: Consequences for amphipod distribution and abundance. J. Exp. Mar. Bio. Ecol. 38, 225-245. doi:10.1016/0022-0981(79)90069-8

Nelson, W.G., Cairns, K.D., Virnstein, R.W., 1982. Seasonality and Spatial Patterns of Seagrass-Associated Amphipods of the Indian River Lagoon, Florida. Bull. Mar. Sci. 32, 121-129.

Noe, G.B., Childers, D.L., Jones, R.D., 2001. Phosphorus Biogeochemistry and the Impact of Phosphorus Enrichment: Why Is the Everglades so Unique? Ecosystems 4, 603-624. doi:10.1007/s10021-001-0032-1

Noss, R.F., 1990. Indicators for monitoring biodiversity: A hierarchical approach. Conserv. Biol. 4, 355-364.

Nuttle, W.K., Fourqurean, J.W., Cosby, B.J., Zieman, J.C., Robblee, M.B., 2000. Influence of net freshwater supply on salinity in Florida Bay. Water Resour. Res. 36, $1805-1822$.

O’Brien, R.G., Kaiser, M.K. 1985. MANOVA method for analyzing repeated measures designs: An extensive primer.

Oksanen J, Blanchet FG, Kindt R, Legendre P, Minchin PR, O’Hara RB, Simpson GL, Solymos P, Henry M, Stevens H, Wagner H. 2015. vegan: Community Ecology Package. R package version 2.3-2. http://CRAN.R-project.org/package=vegan 
Orth, R.J., Carruthers, T.I.M.J.B., Dennison, W.C., Duarte, C.M., James, W., Jr, K.L.H., Hughes, A.R., Kendrick, G.A., Kenworthy, W.J., Olyarnik, S., Short, F.T., Waycott, M., Williams, S.L., 2006. A global crisis for seagrass ecosystems. Bioscience 56, 987-996.

Orth, R.J., Heck, K.L., van Montfrans, J., 1984. Faunal communities in seagrass beds: A review of the influence of plant structure and prey characteristics on predator:prey relationships. Estuaries 7, 339. doi:10.2307/1351618

Powell, A.B., Thayer, G., Lacroix, M., Cheshire, R., 2007. Juvenile and small resident fishes of Florida Bay, a critical habitat in the Everglades National Park, Florida.

R Core Team (2015). R: A language and environment for statistical computing. R Foundation for statistical computing, Vienna, Austria. URL http://www.Rproject.org/.

Reish, D.J., Barnard, J.L., 1079. Amphipods (Arthropoda: Crustacea: Amphipoda), in: Hart, C.W.J., Fuller, S.L.H. (Eds.), Pollution Ecology of Estuarine Invertebrates. Academic Press, New York, pp. 345-370.

Rosenberg, G., Ramus, J., 1984. Uptake of inorganic nitrogen and seaweed surface area:volume ratios. Aquat. Bot. 19, 65-72. doi:10.1016/0304-3770(84)90008-1

Rudnick, D.T., Chen, Z., Childers, D.L., Boyer, J.N., Fontaine, T.D., 1999. Phosphorus and nitrogen inputs to Florida Bay: The importance of the Everglades watershed. Estuaries 22, 398. doi:10.2307/1353207

Russo, A.R., 1987. Role of habitat complexity in mediating predation by the gray damselfish Abudefduf sordidus on epiphytal amphipods. Mar. Ecol. Prog. Ser. 36, 101-105.

Schneider, F.I., Mann, K.H., 1991. Species specific relationships of invertebrates to vegetation in a seagrass bed. II. Experiments on the importance of macrophyte shape, epiphyte cover and predation. J. Exp. Mar. Bio. Ecol. 145, 119-139. doi:10.1016/0022-0981(91)90009-L

Sheridan, P.F., 1980. Three new special [sic] of Melita (Crustacea: Amphipoda), with notes on the amphipod fauna of the Apalachicola estuary of northwest Florida. Northeast Gulf Sci. 3, 60-73.

Sheridan, P.F., Livingston, R.J., 1983. Abundance and seasonality of infauna and epifauna inhabiting a Halodule wrightii meadow in Apalachicola Bay, Florida. Estuaries 6, 407. doi:10.2307/1351400 
Short, F.T., Polidoro, B., Livingstone, S.R., Carpenter, K.E., Bandeira, S., Bujang, J.S., Calumpong, H.P., Carruthers, T.J.B., Coles, R.G., Dennison, W.C., Erftemeijer, P.L.A., Fortes, M.D., Freeman, A.S., Jagtap, T.G., Kamal, A.H.M., Kendrick, G.A., Judson Kenworthy, W., La Nafie, Y.A., Nasution, I.M., Orth, R.J., Prathep, A., Sanciangco, J.C., Tussenbroek, B. van, Vergara, S.G., Waycott, M., Zieman, J.C., 2011. Extinction risk assessment of the world's seagrass species. Biol. Conserv. 144, 1961-1971. doi:10.1016/j.biocon.2011.04.010

Short, F.T., Wyllie-Echeverria, S., 2009. Natural and human-induced disturbance of seagrasses. Environ. Conserv. 23, 17. doi:10.1017/S0376892900038212

Stoner, A.W., 1983. Distributional ecology of amphipods and tanaidaceans associated with three sea grass species. J. Crustac. Biol. 3, 505-518.

Stoner, A.W., 1980. The role of seagrass biomass in the organization of benthic macrofaunal assemblages. Bull. Mar. Sci. 30, 537-551.

Stoner, A.W., 1980. Perception and choice of substratum by epifaunal amphipods associated with seagrasses. Mar. Ecol. Prog. Ser. 3, 105-111.

Stoner, A.W., 1979. Species-specific predation on amphipod crustacea by the pinfish Lagodon rhomboides: Mediation by macrophyte standing crop. Mar. Biol. 55, 201207. doi:10.1007/BF00396819

Stoner, A.W., Lewis, F.G., 1985. The influence of quantitative and qualitative aspects of habitat complexity in tropical sea-grass meadows. J. Exp. Mar. Bio. Ecol. 94, 19-40.

Tararam, A.S., Wakabara, Y., Leite, F.P.P., 1986. Vertical distribution of amphipods living on algae of a Brazilian intertidal rocky shore. Crustaceana 51, 183-187.

Thayer, G.W., S.M. Adams, and M.W. LaCroix. 1975. Structural and functional aspects of a recently established Zostera marina community. pp. 518-540 in: L.E. Cronin (Ed.) Estuarine Research. Academic Press, New York, New York.

Thomas, J.D., 1993. Biological monitoring and tropical biodiversity in marine environments: a critique with recommendations, and comments on the use of amphipods as bioindicators. J. Nat. Hist. 27, 795-806.

doi:10.1080/00222939300770481

Virnstein, R.W., Howard, R.K., 1987. Motile epifauna of marine macrophytes in the Indian River Lagoon, Florida. I. Comparisons among three species of seagrasses from adjacent beds. Bull. Mar. Sci. 41, 1-12. 
von Ende, C.N., 2001. Repeated-measures analysis: growth and other time-dependent measures, in: Scheiner, S.M., Gurevitch, J. (Eds.), Design and Analysis of Ecological Experiments. Oxford University Press, Oxford, UK, pp. 134-157.

Wilson, K.G., Ralph, P.J., 2008. A comparison of the effects of Tapis crude oil and dispersed crude oil on subtidal Zostera capricorni. Int. Oil Spill Conf. Proc. 2008, 859-864. doi:10.7901/2169-3358-2008-1-859

Winer BJ, Brown DR, Michels KM (1991) Statistical principles in experimental design. McGraw-Hill, New York

Worm, B., Sommer, U., 2000. Rapid direct and indirect effects of a single nutrient pulse in a seaweed-epiphyte-grazer system. Mar. Ecol. Prog. Ser. 202, 283-288. doi:10.3354/meps202283

Young, D.K., 1978. Regulation of species densities of seagrass-associated macrobenthos: evidence from field experiments in the Indian River estuary, Florida. J. Mar. Res. $36,569-593$.

Young, D.K., Buzas, M.A., Young, M.W., 1976. Species densities of macrobenthos associated with seagrass: a field experimental study of predation. J. Mar. Res. 34, 577-592.

Zieman, J.C., Fourqurean, J.W., Iverson, R.L., 1989. Distribution, abundance and productivity seagrasses and macroalgae in Florida Bay. Bull. Mar. Sci. 44, 292 311. 


\section{CHAPTER IV}

HABITAT FRAGMENTATION HAS WEAK IMPACTS ON ASPECTS OF ECOSYSTEM FUNCTIONING IN A SUB-TROPICAL SEAGRASS BED 


\begin{abstract}
Habitat fragmentation impacts ecosystem functioning in many ways, including reducing the availability of suitable habitat and altering resource dynamics. Fragmentation in seagrass ecosystems caused by propeller scarring is a major source of habitat loss, but little is known about how scars impact ecosystem functioning. Propeller scars were simulated in seagrass beds of Abaco, Bahamas, to explore impacts of scarring. To determine if plant-herbivore interactions were altered by fragmentation, amphipod grazers were excluded from half the experimental plots, and epiphyte biomass and community composition were compared between grazer control and exclusion plots. We found a shift from light limitation to phosphorus limitation at seagrass patch edges. Fragmentation did not impact top-down control on epiphyte biomass or community composition, despite reduced amphipod density in fragmented habitats. Seagrass and amphipod responses to propeller scarring suggest that severely scarred seagrass beds could be subject to changes in internal nutrient stores and amphipod redistribution.
\end{abstract}

Keywords: Habitat fragmentation, disturbance, food-webs, plant-herbivore interactions, stoichiometry, amphipod, epiphytes, seagrass 


\section{Introduction}

Habitat fragmentation is a process through which a continuous landscape is broken into multiple fragments or patches (Laurance et al. 2002; Feeley \& Terborgh 2008) often resulting in reduced areal coverage, increased frequency of edge habitats, and increased predation risk (Turner et al. 2001). In coastal marine ecosystems, habitat fragmentation can be a natural process driven by waves or currents (Fonseca et al. 1998), but anthropogenically-driven seagrass meadow fragmentation is increasing in frequency and severity due to high levels of boat traffic, dredging, and eutrophication (Short et al. 2011). Nearly half of all seagrass species are affected by mechanical damage including that caused by boat propellers (Short et al. 2011). The rate of seagrass loss has accelerated in recent decades with global seagrass coverage reduced by one-third since 1879. These losses are associated with substantial loss of ecosystem services (Waycott et al. 2009).

Fragmentation decreases habitat area and increases the amount of edge habitat present. Edges are dynamic regions characterized by variable environments including, temperatures, water or airflow, and habitat complexity (Turner et al. 2001; Bologna \& Heck 2002; Ries \& Sisk 2010). As such, the increased variability in edge habitats can affect the ecological relationships among organisms (e.g., herbivory and predation). Decreases in faunal abundances at the edge of seagrass patches are often attributed to increased predation (Irlandi 1994, Bell et al. 2001, Peterson et al. 2001, Uhrin \& Holmquist 2003). For example, Uhrin and Holmquist (2003) found crab and mollusk densities were lower up to $5 \mathrm{~m}$ away from recently-made scars in seagrass meadows 
(Uhrin \& Holmquist 2003). Conversely, some invertebrate prey species, including gammaridean amphipods, are found at higher densities at edge compared to interior regions (Bologna \& Heck 1999, Eggleston et al. 1999, Arponen \& Boström 2012). Amphipods are hypothesized to settle in these edge habitats because current flow is reduced by the aboveground structure of seagrass (Fonseca et al. 1982), providing a more amenable environment in which amphipods settle (Tanner 2003). Amphipods are also known to drift on macroalgae across bare substrate (Schneider \& Mann 1990, Holmquist 1994). Once they come into contact with a suitable habitat, usually the edge of a seagrass patch, they colonize the area (Virnstein \& Curran 1986, Tanner 2003, Arponen \& Boström 2012).

Gammaridean amphipods are important grazers in seagrass systems, consuming a wide range of macro- and micro-algae growing on the substrate or epiphytically on seagrass leaves. Gammaridean amphipods have strong impacts on regulating epiphyte growth on seagrasses (Orth and van Montfrans 1984, Neckles et al. 1993, Duffy and Hay 2000, Duffy and Harvilicz 2001, Hughes et al. 2004, Jaschinski and Sommer 2008, Spivak et al. 2009, Cook et al. 2011, Whalen et al. 2013), and can reduce the impacts of epiphyte-induced shading of seagrasses even under eutrophic conditions (Neckles et al. 1993, Heck et al. 2000, Hughes et al. 2004; McSkimming et al. 2015). Species identity, richness, and diversity of amphipods mediates the top-down effect of amphipods on seagrasses. A diverse amphipod community reduce epiphyte abundance on seagrass leaves because different amphipod species have different feeding preferences and abilities (Duffy and Harvilicz 2001). 
Amphipods are a major food source for many juvenile and smaller predatory fish and decapod species, making amphipods an important energy link from primary producers to higher trophic levels (Brook 1977; Young \& Young 1978). High amphipod grazer diversity can improve energy transfer up to higher trophic levels by increased secondary production (Duffy et al. 2003). Grazer diversity facilitates more complete use of epiphyte resources (Duffy et al. 2001) and, depending on the composition of grazer species, can even increase seagrass biomass indirectly via epiphyte removal (Duffy et al. 2003).

Studies examining amphipod responses to fragmentation have previously been conducted using small, artificial, seagrass patches in unvegetated habitats adjacent to continuous seagrass beds (Healey \& Hovel 2004; Arponen \& Boström 2012; Pierri-Daunt \& Tanaka 2014). These projects increased understanding of amphipod behavior in response to patch size and level of isolation from the main seagrass patch, but did not focus on habitat fragmentation, per se (see Fahrig 2003). A study focusing on the effects of active fragmentation, found a reduction in the abundance of amphipods in response to the fragmentation of a previously continuous, artificial, seagrass landscape with no response to edge habitats (Pierri-Daunt \& Tanaka 2014). They attribute the reduction in amphipod abundance to habitat loss.

Seagrass ecosystems can be highly fragmented, often because of propeller scars from motor boats (Zieman 1976, Sargent et al. 1995, Bell et al. 2002), which can have long lasting effects, with recolonization by later successional species taking decades (Zieman 1976, Kenworthy et al. 2002, Di Carlo and Kenworthy 2008, Uhrin et al. 2011). Despite their prevalence in shallow, vegetated areas, little is known about how scars 
affect the functioning of seagrass ecosystems. The objective of this study was to examine if fragmentation via propeller scarring impacts the structure and function of seagrass ecosystems, as mediated by changes in resource availability and amphipod grazer communities (Table 4.1). To test this, we simulated propeller scars in a seagrass bed on Abaco, Bahamas. Additionally, we measured the effects of grazers on epiphyte communities by removing grazers from half our experimental plots to disentangle the potentially confounding effects of increasing edge habitat and potentially altered amphipod distribution and community structure within seagrass patches. We evaluated seagrass primary production (hypothesis 1) and nutrient and isotopic content (hypotheses 2-3), epiphyte biomass and community structure (hypotheses 4-5), grazer abundance and community structure (hypotheses 6-7, and plant-grazer interactions (hypothesis 8) as measures of ecosystem functioning.

\section{Materials and methods}

\subsection{Site Description and Experimental Design}

The study was conducted at two sites in Abaco, The Bahamas $\left(26^{\circ} 25^{\prime} \mathrm{N}\right.$, $77^{\circ} 10^{\prime} \mathrm{W}$ ) from August to October 2014. The sites, Cherokee Sound and Jungle Creek, were characterized by depths of $1.5 \mathrm{~m}$ at high tide with $>50 \%$ Thalassia testudinum cover (Fig. 4.1). Forty experimental plots were established across a continuous seagrass landscape, and replicates of each treatment combination $(n=10)$ were randomly assigned (Fig. 4.2). Amphipod abundance (called Grazing) and fragmentation treatments were manipulated over the course of 5 weeks at the two sites (one factor in the design). The 
factor of Grazing consisted of two levels (amphipod exclusion and control). The factor of Fragmentation consisted of two levels (fragmented and continuous control). Edge and interior sampling plots were nested within the fragmented treatment to test for edge effects (Table 4.2). Seagrass, amphipod, and epiphyte samples were collected within 15 $\mathrm{cm}$ of carbaryl blocks or control plot markers at continuous, interior, and edge locations at the end of the experiment.

\subsection{Fragmentation Treatment}

Plots were chosen based on homogeneous cover of benthic vegetation (seagrasses and macroalgae) across a circular area $6.5 \mathrm{~m}$ in diameter, then were randomly assigned as a control or fragmented treatment. A simulated propeller scar was created around the circumference of the fragmented plots to a width of $25 \mathrm{~cm}$ (approximate width of propeller scars in the area) using hedge clippers. Seagrasses and macroalgae were removed at the sediment surface, and regrowth was trimmed weekly. Rhizomes were severed at the scar edge to prevent transfer of nutrients from adjacent short shoots. All experimental plots had a diameter of $6.5 \mathrm{~m}(6 \mathrm{~m}$ internal diameter and $0.25 \mathrm{~m}$ propeller scar on both sides for fragmented plots, $6.5 \mathrm{~m}$ diameter for continuous plots) with an area of $33.2 \mathrm{~m}^{2}$. All plot centers were $10 \mathrm{~m}$ apart to minimize cross-contaminating treatments (Fig. 4.2).

To test for fragmentation effects, samples were collected from the center of both fragmented and continuous plots. Samples were also collected from the edges and interior locations of a fragmented patch to test for edge effects (Table 4.2; Fig. 4.2). Edge plots were randomly assigned a cardinal direction to control for the potential effects of current. 


\subsection{Grazer Treatment}

Amphipods were excluded from half of the experimental plots using carbarylinfused plaster blocks as a test of hypothesis 8: amphipod grazing will be reduced at edge habitats (Table 1). Carbaryl is a water-soluble arthropod deterrent used to remove insects in agriculture (Tomlin 2000). Current marine applications include removal of arthropod pests in oyster farms (Dumbauld et al. 2001) and parasitic sea lice in fish farms (Høy \& Horsberg 1991). Carbaryl has a half-life of 5 hours in seawater and degrades rapidly in the presence of light (undetectable after 96 h; Armbrust \& Crosby 1991). Carbaryl effectively removes invertebrates, such as, amphipods, some gastropods, and burrowing shrimp (Duffy \& Hay 2000, Dumbauld et al. 2001, Douglass et al. 2008, Poore et al. 2009, Cook et al. 2011, Whalen et al. 2013, Duffy et al. 2015), with no lasting effects on fish, molluscs, polychaetes, seagrasses or algae (Carpenter 1986, Roth et al. 1993, Dumbauld et al. 2001, Poore et al. 2009).

Slow-release blocks were infused with a low concentration of carbaryl pesticide using $18.5 \mathrm{~g}$ carbaryl to $222 \mathrm{~mL}$ water and $555 \mathrm{~g}$ plaster of paris (3.3\% carbaryl by dry weight plaster; Whalen et al. 2013) and secured to the sediment surface using wire hooks. Carbaryl blocks were replaced weekly to maintain grazer exclusion. Control plots were unmanipulated (i.e., no block). Block controls (plaster blocks without carbaryl) were not used because data from a pilot experiment found no significant difference in amphipod abundances between the control block and ambient control plots $(\mathrm{p}=0.910$, and in Whalen et al. 2013). In our pilot studies, carbaryl successfully excluded amphipods from sample plots up to a distance of $30 \mathrm{~cm}$ from the treatment block ( $\mathrm{p}<0.05$; and in Whalen et al. 2013). 


\subsection{Seagrass Responses}

Abundance of all benthic flora was estimated as percent cover of each species

present in a $0.25 \mathrm{~m}^{2}$ quadrat placed at each sample location. Shoot density was calculated by counting shoots in a $0.02 \mathrm{~m}^{2}$ quadrat at each sample location. Thalassia testudinum productivity rates were estimated using the modified hole-punch technique (Fourqurean et al. 2001). Shoots were marked adjacent to the sample location (Fig. 4.2), and three to seven marked shoots were harvested a week later to measure morphometrics (leaf length and width) and determine areal productivity $\left(\mathrm{g} \mathrm{m}^{-2} \mathrm{~d}^{-1}\right)$. All destructive sampling was conducted at the end of the experiment after amphipod samples had been collected. In the lab, shoots marked for productivity were gently scraped free of epiphyte material, processed for growth metrics, and dried in an oven at $60^{\circ} \mathrm{C}$. Epiphytes were stored in foilwrapped scintillation vials in the freezer until further processing. Dried seagrass shoots were weighed and homogenized for nutrient and isotopic analyses. Total phosphorus content of T. testudinum leaves was determined using a dry-oxidation, acid hydrolysis extraction with colorimetric analysis (Fourqurean et al. 1992). Carbon and nitrogen content were analyzed using a CHN analyzer (Fisions NA1500).

Seagrass blade tissue from Cherokee Sound were analyzed for stable isotope ratios $\left(\delta^{13} \mathrm{C}, \delta^{15} \mathrm{~N}\right)$. Samples used for isotope analyses were fumed for 7 days with concentrated $\mathrm{HCl}$ to remove any carbonates, and re-dried in an oven at $60^{\circ} \mathrm{C}$ to a constant weight. Stable isotope content was determined using elemental analyzer isotope ratio mass spectrometer (EA-IRMS) procedures. Organic matter was combusted in the elemental analyzer and gases were reduced to $\mathrm{N}_{2}$ and $\mathrm{CO}_{2}$, which were measured on a Finnigan MAT Delta C IRMS in continuous flow mode. Results are presented in standard 
delta notation $(\delta)$ using the international standards of atmospheric nitrogen $\left(\mathrm{N}_{2}\right)$ and Vienna Pee Dee belemnite (V-PDB) for carbon. Based on sample replicates, reproducibility of reported $\delta$ values was better than $\pm 0.08 \%$ for carbon and $\pm 0.20 \%$ o for nitrogen.

\subsection{Epiphyte Responses}

High performance liquid chromatography (HPLC) was used to determine phytopigment abundance per sample, which measures relative concentrations of the accessory pigments fucoxanthin (found in diatoms), peridinin (found in dinoflagellates), zeaxanthin and echinenone (found in cyanobacteria), and chlorophyll $b$ (found in chlorophytes). Pigment abundance was estimated as $\mu \mathrm{g}$ pigment per $\mathrm{cm}^{2}$ seagrass leaf, and were presented as a percentage of the sum of the masses of all measured pigments. Abundances of these different pigments were used as indicators of the relative biomass, as taxon-specific chlorophyll $a$, for the various photosynthetic epiphyte groups. Scraped epiphyte material was lyophilized to obtain a dry weight. Epiphyte pigments were extracted using methanol/acetone/N,N-dimethylformamide/water (Hagerthey et al. 2006) and analyzed using HPLC analysis according to the methods described in Louda et al. (1998). Total epiphyte load was estimated as leaf-specific chlorophyll $a$ ( $\mu \mathrm{g}$ Chl $a$ leaf $\left.\operatorname{area}^{-1}\right)$. Epiphyte autotrophic index ( $\mu \mathrm{g}$ Chl $a \mathrm{~g}^{-1}$ epiphyte dry mass) was also calculated.

\subsection{Amphipod identification}

Amphipod samples were collected at all grazer exclusion or grazer control treatments using a modified Virnstein Grabber (Virnstein \& Howard 1987). The 
Virnstein Grabber collects seagrass above-ground biomass and associated epifauna from an area of $400 \mathrm{~cm}^{2}$ without collecting sediment or infauna (Douglass et al. 2008). Samples were rinsed through $400 \mu \mathrm{m}$ filter bags, transported on ice and then frozen. In the lab, samples were thawed and seagrass and macroalgae removed. The remaining sample was filtered through a $500 \mu \mathrm{m}$ sieve to remove sediment from the sample. Fauna collected in the sieve were then preserved in 5\% formalin before being rinsed, identified, and stored in $70 \%$ ethanol. Seagrass and algae were dried to a constant weight at $60^{\circ} \mathrm{C}$ then combusted at $500^{\circ} \mathrm{C}$ for four hours to determine ash-free dry weight (AFDW). Amphipods were identified to the species level (following LeCroy 2002) under a dissecting microscope. Amphipod density per g macrophyte biomass was calculated for each species as amphipod abundance divided by AFDW (number of amphipods $\mathrm{g}^{-1}$ macrophyte AFDW per $400 \mathrm{~cm}^{2}$ sample)(Whalen et al. 2013).

\subsection{Statistical Analyses}

Univariate statistical analyses were conducted using R Studio (R development core team 2015) and the following packages: 'car' (Fox \& Weisberg 2011), 'nlme' (Pinheiro et al. 2016), 'multcomp' (Hothorn et al. 2008), and 'MASS' (Venables \& Ripley 2002). Because interior and edge locations do not meet the assumption of independence for ANOVA when analyzing for fragmentation effects, we created two separate datasets. The first dataset includes data collected from fragmented-interior and continuous plots only, and is used to test for fragmentation effects between sites, habitats, grazer treatments, and all interaction terms in a 3-way analysis of variance (ANOVA). The second dataset includes data collected from fragmented-edge and interior plots, and 
was used to test for an effect of the edge. All analyses testing for edge effects were done using 2-way ANOVA within each site (two separate analyses), thereby removing site as a factor in the model (Table 4.2). Dependent variables were epiphyte biomass and autotrophic index, and seagrass abundance, productivity, and nutrient content ( $\mathrm{N}$ and $\mathrm{P}$ ).

Stable isotopic content $\left(\delta^{13} \mathrm{C}\right.$ and $\left.\delta^{15} \mathrm{~N}\right)$ of seagrass leaves in fragmentation and grazing treatments (Cherokee Sound only) were analyzed using 2-way ANOVA. Edge effects, or within-patch differences, in isotopic content between fragmentation and grazer treatments also were analyzed using 2-way ANOVA.

Community analyses were conducted using Primer 6 software (version 6.1.15;

Primer-E 2012). Epiphyte communities, as described by the accessory pigment relative abundances, were analyzed using a 3-factor permutational analysis of variance (PERMANOVA) where site, fragmentation, and grazer treatment were the three main factors. Differences in amphipod community structure between sites and fragmentation treatments were determined using Bray-Curtis dissimilarity index calculated on a matrix of amphipod densities of each species. Differences in community structures were visually examined using nonmetric multidimensional scaling (nMDS) ordination (Fig. 4.7 generated using the vegan package in R; Oksanen et al. (2015)), and significance was determined using PERMANOVA. The most influential taxa contributing to observed differences were determined using similarity percentage (SIMPER) analyses for both epiphyte and amphipod communities. 


\section{Results}

\subsection{Overview}

Thalassia testudinum cover was significantly higher at Cherokee Sound $(P<0.001$, $\bar{x}=80 \%)$ than Jungle Creek $(\bar{x}=62 \%)$ (Table 4.3). The habitat was more complex at Cherokee Sound, with significantly longer leaves, greater leaf area per short shoot, more leaves per short shoot, higher short shoot density, and larger standing crop biomass (all $P<0.001$ ). Productivity (areal productivity $\mathrm{g} \mathrm{m}^{-2} \mathrm{day}^{-1}$, and leaf area productivity $\mathrm{cm}^{-2} \mathrm{~m}^{-2}$ day $\left.^{-1}\right)$ of T. testudinum was significantly higher at Cherokee Sound as well $(P<0.001$ for both) (Table 4.3).

\subsection{Seagrass responses to fragmentation}

Thalassia testudinum abundance ranged from $40 \%$ to $100 \%$ cover at Cherokee Sound and $28 \%$ to $100 \%$ at Jungle Creek at the end of the experiment. Thalassia testudinum abundance was significantly higher in continuous habitats $(\bar{x}=76 \%)$ than interior $(P=0.025 ; \bar{x}=66 \%$ cover $)$ and edge $(P=0.021 ; \bar{x}=65 \%$ cover $)$ habitats. Within fragmented plots, $T$. testudinum cover was not significantly different between edge and interior locations, or grazer treatment plots.

Seagrass nutrient content $(\mathrm{C}, \mathrm{N}, \mathrm{P})$ was significantly different between sites. Carbon and nitrogen were significantly higher at Jungle Creek ( $\bar{x}=38.47$ for carbon; $\bar{x}=2.12$ for nitrogen) than at Cherokee Sound $(\mathrm{p}<0.0001 ; \bar{x}=35.02$ for carbon; $\bar{x}=1.91$ for nitrogen), but were not different across within-patch locations or grazer treatments at either site (Fig. 4.3). Phosphorus (\%P) was significantly higher at Cherokee Sound 
$(\bar{x}=0.066 \% ; P<0.001)$ than Jungle Creek $(\bar{x}=0.059 \%)$. Phosphorus was not affected by fragmentation (fragmented-interior vs. continuous plots) or grazer treatments. At Jungle Creek, there was no effect of edge on \%P in seagrass tissues (Fig. 4.4a), 4.but \% P was significantly higher in plots where grazers were present ( $P=0.014$; Fig. $4.4 \mathrm{~b})$. Conversely, $\% \mathrm{P}$ was higher at continuous plots $(\bar{x}=0.069 ; P=0.001)$ than edges $(\bar{x}=0.058 \%$; Fig. 4.4c) in Cherokee Sound, but was unaffected by grazer treatment (Fig. 4.4d).

Stable isotope content $\left(\delta^{13} \mathrm{C}\right.$ and $\left.\delta^{15} \mathrm{~N}\right)$ was analyzed in seagrass tissues at Cherokee Sound because of the observed depletion of $\mathrm{P}$ at edges. $\delta^{13} \mathrm{C}$ was significantly enriched $(P=0.004)$ at edges $(\bar{x}=-9.53)$ than continuous $(\bar{x}=-10.37)$ habitats. $\delta^{13} \mathrm{C}$ was similar between edge and interior, and continuous and interior locations. No significant differences between habitats were detected for $\delta^{15} \mathrm{~N}$. Both $\delta^{13} \mathrm{C}$ and $\delta^{15} \mathrm{~N}$ appeared unaffected by fragmentation and grazer treatments. A weak but significant, negative relationship $\left(P=0.01, \mathrm{R}^{2}=0.09\right)$ was detected between $\delta^{13} \mathrm{C}$ and phosphorus content (Fig. 4.5).

\subsection{Epiphyte responses to fragmentation and grazing}

Leaf-specific epiphyte biomass ranged from 0.02-2.38 $\mu \mathrm{g} \mathrm{Chl} a$ leaf area ${ }^{-1}$ at Cherokee Sound and 0.02-6.91 $\mu \mathrm{g} \mathrm{Chl} a$ leaf area $^{-1}$ at Jungle Creek. Fragmented habitats ranged from 0.18-1.85 $\mu \mathrm{g} \mathrm{Chl} a$ leaf area ${ }^{-1}$ and 0.15-2.38 $\mu \mathrm{g} \mathrm{Chl} a$ leaf area ${ }^{-1}$ at continuous habitats. Grazer control treatments ranged from 0.02-2.38 $\mu \mathrm{g} \mathrm{Chl} a$ leaf area ${ }^{-1}$, while grazer exclusion plots ranged from 0.09-6.91 $\mu \mathrm{g} \mathrm{Chl} a$ leaf area ${ }^{-1}$. Edge habitats ranged from 0.02-2.29 $\mu \mathrm{g} \mathrm{Chl} a$ leaf area ${ }^{-1}$ at Cherokee Sound and 0.02-6.91 $\mu \mathrm{g} \mathrm{Chl} a$ 
leaf area $^{-1}$ Jungle Creek. Leaf-specific epiphyte biomass was not significantly different for site, fragmentation, or grazer treatments, nor were there significant edge effects within sites (Table 4.4).

Epiphyte autotrophic indices ranged from 79.79-1439.12 $\mu \mathrm{g} \mathrm{Chl} a \mathrm{~g}^{-1}$ epiphyte dry mass at Cherokee Sound and 23.27-559.50 $\mu \mathrm{g} \mathrm{Chl} a \mathrm{~g}^{-1}$ epiphyte dry mass at Jungle Creek. Fragmented habitats ranged from $143.59-483.45 \mu \mathrm{g} \mathrm{Chl} a \mathrm{~g}^{-1}$ epiphyte dry mass and 60.68-703.88 $\mu \mathrm{g} \mathrm{Chl} a \mathrm{~g}^{-1}$ epiphyte dry mass at continuous habitats. Grazer control treatments ranged from 23.27-1439.12 $\mu \mathrm{g} \mathrm{Chl} a \mathrm{~g}^{-1}$ epiphyte dry mass, while grazer exclusion plots ranged from 27.99-663.85 $\mu \mathrm{g} \mathrm{Chl} a \mathrm{~g}^{-1}$ epiphyte dry mass. Edge habitats ranged from 180.54-483.45 $\mu \mathrm{g} \mathrm{Chl} a \mathrm{~g}^{-1}$ epiphyte dry mass at Cherokee Sound $(\bar{x}=$ 346.70 $\mu \mathrm{g} \mathrm{Chl} a \mathrm{~g}^{-1}$ epiphyte dry mass) and 143.59-367.54 $\mu \mathrm{g}$ Chl $a \mathrm{~g}^{-1}$ epiphyte dry mass at Jungle Creek ( $\bar{x}=233.87 \mu \mathrm{g} \mathrm{Chl} a \mathrm{~g}^{-1}$ epiphyte dry mass). Epiphyte autotrophic indices were significantly higher $(P<0.005)$ at Cherokee Sound than at Jungle Creek. The higher autotrophic index at Cherokee Sound suggests the presence of epiphytes with more chlorophyll $a$ relative to their total mass. Within-patch analyses of the epiphyte autotrophic indices were not significantly different among plots for either site (Table 4.4).

The dominant epiphyte phototrophic groups identified in this study were diatoms (average relative abundance across sites: 56.7\%) and chlorophytes (average relative abundance across sites: $32.1 \%$ ). Dinoflagellates (average relative abundance across sites: 8.2\%) and cyanobacteria (average relative abundance across sites: $3.0 \%$ ) were identified as well, but in lower abundances. Epiphyte community composition was significantly different between sites ( $P=0.001$; Fig. 4.6), but was unaffected by fragmentation and grazer treatments. Diatoms were the most abundant epiphyte group at Cherokee Sound 
(74.4\% average relative abundance), and chlorophytes were the most abundant epiphyte group at Jungle Creek (52.6\% average relative abundance). Within sites, epiphyte community composition was not significantly different across fragmentation or grazer treatments.

\subsection{Amphipod responses}

A total of 314 individual amphipods were collected from 7 families representing 14 unique taxa. At Cherokee Sound, 188 individuals were collected from 3 families representing 7 different species. Jungle Creek was more diverse with 126 individuals collected from 6 families representing 10 species. Of the collected amphipods, 2 families representing 3 species were collected at both sites (Family Aoridae: Grandidierella bonnieroides; Family Ampithoidae: Cymadusa compta and C. filosa). Amphipod density ranged from 0-1.63 amphipods $\mathrm{g}^{-1}$ seagrass AFDW at Cherokee Sound and 0-3.85 amphipods $\mathrm{g}^{-1}$ seagrass AFDW at Jungle Creek. Amphipod densities ranged from 0-3.85 amphipods $\mathrm{g}^{-1}$ AFDW in continuous habitats and from $0-1.73$ amphipods $\mathrm{g}^{-1}$ seagrass AFDW in fragmented habitats. In grazer treatments, amphipod density ranged from 03.85 amphipods $\mathrm{g}^{-1}$ seagrass AFDW in grazer exclusion plots and 0-2.92 amphipods $\mathrm{g}^{-1}$ seagrass AFDW in grazer control plots. Amphipod density was not significantly different between sites or fragmented treatments, but was lower in grazer exclusion plots $(\bar{x}=0.36$ amphipods $\mathrm{g}^{-1}$ seagrass AFDW; $\left.\mathrm{p}=0.002\right)$ than grazer control plots $(\bar{x}=0.61$ amphipods $\mathrm{g}^{-1}$ seagrass AFDW). The interaction between Site and Grazer treatments was significant $(P=0.043)$. Amphipod density was higher in grazer control plots $\left(\bar{x}=0.59\right.$ amphipods $\mathrm{g}^{-1}$ seagrass AFDW) than exclusion plots ( $\bar{x}=0.24$ amphipods $\mathrm{g}^{-1}$ seagrass AFDW) at 
Cherokee Sound (Tukey HSD post hoc analysis; $P=0.002$ ). No significant differences between grazer control and exclusion plots were observed at Jungle Creek indicating carbaryl was ineffective at this site. Carbaryl use to understand the ecological interactions between amphipods and primary producers is widespread in temperate seagrass ecosystems (see Duffy et al. 2015). The efficacy of carbaryl in tropical study systems, however, has been inconclusive to date (J. Campbell, personal communication). We caution against assuming carbaryl is universally effective in eliminating amphipod grazers from seagrass beds, even when study sites are in relative close proximity as in our study.

Because of the significant Site*Grazer treatment interaction, and the ineffectiveness of carbaryl at Jungle Creek we removed the grazer exclusion plots from the analyses for fragmentation and edge effects on amphipod density. Amphipod density was significantly reduced in fragmented plots $(\mathrm{P}=0.004)$, but not significantly impacted by edges (i.e., no difference between interior or edge locations) at Cherokee Sound or Jungle Creek.

Amphipod communities had a different composition between sites $(P<0.001)$, but were unaffected by fragmentation. The most common species identified at Cherokee Sound included Ampithoe ramondi (relative abundance $=34 \%$ ), Elasmopus levis (relative abundance $=24 \%$ ), and Cymadusa filosa (relative abundance $=23 \%)$. At Jungle Creek, Plesiolembos rectangulatus (relative abundance $=47 \%$ ), Grandidierella bonnieroides (relative abundance $=13 \%)$, Bemlos unicornis $($ relative abundance $=13 \%)$, and Shoemakerella cubensis (relative abundance $=8 \%$ ) were the most abundant species. 
Within sites, amphipod community composition was not significantly different between edge and interior treatments (Fig. 4.7).

\section{Discussion}

Habitat fragmentation in Bahamian seagrass meadows caused some changes in the functioning of seagrass ecosystems. The most obvious pattern occurred in edge habitats, i.e., a concurrent nutrient depletion and heavier $\delta^{13} \mathrm{C}$ which are indicative of increased light availability in seagrass ecosystems (Abal et al. 1994, Campbell \& Fourqurean 2009). While habitat fragmentation had no impact on amphipod and epiphyte community structure, amphipod density was reduced in fragmented patches. Changes in amphipod density (reductions in fragmented patches and exclusion plots) did not translate to changes in top-down control as evidenced by no change in epiphyte biomass or community composition across study patches. This study highlights the importance of understanding the impacts of habitat fragmentation via propeller scarring on seagrass ecosystem functioning. These data can be especially relevant in seagrass monitoring programs where nutrient and isotope content of photosynthetic tissues are assessed.

\subsection{Resource limitation}

The coastal areas of Abaco, Bahamas, are primarily phosphorus-limited (Allgeier et al. 2010). Allochthonous nutrient input is localized in this region (Stoner et al. 2011), and can influence seagrass productivity and epiphyte community composition. In this experiment, Cherokee Sound was subjected to higher levels of allochthonous nutrient 
input than Jungle Creek because of the close proximity to a larger human population. Allochthonous nutrient inputs at Cherokee Sound could account for increased seagrass productivity, higher phosphorus content, and different epiphyte community composition than at Jungle Creek.

Propeller scarring in Cherokee Sound caused as shift in nutrient and isotopic content of seagrass photosynthetic tissues in edge habitats. Phosphorus content became depleted at edges of plots, while $\delta^{13} \mathrm{C}$ increased, indicating a change in seagrass physiological processes initiated by altering the physical environment. When seagrasses are shaded they have lighter $\delta^{13} \mathrm{C}$ values in photosynthetic tissues (Durako \& Hall 1992; Abal et al. 1994; Campbell \& Fourqurean 2009). Propeller scars remove above- and below-ground tissues creating isolated patches within a larger, continuous, seagrass bed. The removal of plants via scarring relieves adjacent seagrasses from self-shading by allowing increased light penetration, exposing more photosynthetic tissue to light. In general, light is not a limiting factor in this system because of the clear, shallow, water column; however, short-shoot density was quite higher at Cherokee Sound, suggesting the seagrasses here indeed may be self-shading.

\subsection{Plant-herbivore interactions}

Fragmentation created by simulated propeller scars reduced amphipod density overall. This is in contrast with other studies, e.g., no influences of fragmented eelgrass beds or fragment size were detected on epifaunal or nekton communities in eelgrass fragments created in the lower Chesapeake Bay (Lefcheck et al. 2016). In southwest Finland, amphipod densities in fragmented treatments were higher than in continuous 
treatments (Arponen \& Boström 2012), which the authors attributed to an edge effect. In other cases edges, like those created by propeller scars in seagrass beds, can increase predation risk on some invertebrate species causing reduced abundance at edges (scallops: Bologna \& Heck 1999; decapods: Tanner 2005). We found no impact of the presence of the edge on amphipod density (i.e., amphipod densities in edge and interior plots were not significantly different) despite the presence of predators, such as Geres cinereus (yellowfin mojarra) and Lutjanus apodus (schoolmaster snapper; Rooker 1995), at both sites.

Reduced abundance of gammaridean amphipods has also been attributed to the loss of habitat associated with fragmentation. After fragmentation of artificial seagrass patches in Brazil, amphipod abundances were reduced in smaller experimental fragments when compared to larger fragments (Pierri-Daunt \& Tanaka 2014). Abundance of epifauna, including amphipods, was reduced in live seagrass beds in San Diego, California, but only after habitat area was reduced by $90 \%$ (Reed \& Hovel 2006). Amphipod densities were reduced after fragmentation in our study as well, but the amount of habitat loss was much less than $90 \%$ and fragments were embedded within a continuous seagrass bed. The propeller scars may have created a barrier over which amphipods would have been reluctant to cross because of the potentially elevated predation risk in scars. If the propeller scars acted as a barrier isolating amphipods within fragmented patches from the surrounding, continuous seagrass beds, natural top-down control exerted by amphipod predators present at our sites could have resulted in the detected reduction in amphipod densities in fragmented patches. 
Epiphyte biomass (measured as chlorophyll $a$ ) was not significantly different between Jungle Creek and Cherokee Sound despite measured differences in ambient nutrient availability (as determined from seagrass elemental content). Epiphyte chlorophyll $a$, however, is not a sensitive indicator of nutrient availability in oligotrophic seagrass ecosystems (Fourqurean et al. 2010), even under experimental nutrient enrichment (see Armitage et al. 2005, 2006). Accessory phytopigments in epiphytes are more responsive to changes in ambient nutrient content (Armitage et al. 2005; Frankovich et al. 2009) and may be a better metric to investigate.

Epiphyte community composition, however, differed significantly between Cherokee Sound and Jungle Creek. Both sites were dominated by diatoms and chlorophytes, but the relative abundance of each phototrophic group was rather different at each site. Diatoms dominated epiphyte communities at Cherokee Sound, whereas chlorophytes dominated epiphyte communities at Jungle Creek. In Florida Bay, the relative abundance of diatoms decreased with phosphorus enrichment (Frankovich et al 2009) and the relative abundance or chlorophytes ( $\operatorname{chl} b$ ) increased with phosphorus enrichment (Armitage et al. 2006). In Abaco, diatom abundance was higher at Cherokee Sound, the more phosphorus enriched site. Shifts in epiphyte communities were caused by experimental nutrient enrichment in Florida Bay. Experimental nutrient enrichment could promote the colonization of more opportunistic species of microalgal epiphytes by changing the ambient nutrient availability. In Abaco, nutrient enrichment has occurred over a longer time period and is indicative of ambient nutrient availability, not experimental fertilization. As such, epiphyte communities could be more stable and indicative of a climax community under naturally occurring nutrient availability. 
Differences in epiphyte communities could lead to different amphipod communities at our study sites. Gammaridean amphipods exhibit species-specific feeding preferences on epiphytic algae (Duffy and Hay 1994, Duffy and Hay 2000, Duffy and Harvilicz 2001). The dominant amphipod species at Cherokee Sound was Ampithoe ramondi, which accounted for $34 \%$ of amphipods collected. A. ramondi feeds primarily on diatoms and filamentous green algae (Brawley \& Adey 1981). Elasmopus levis and Cymadusa filosa consisted of $24 \%$ and $23 \%$ of the sampled amphipod community, respectively, and both species graze on chlorophytes (Buza-Jacobucci \& Pereira-Leite 2014; Ceh et al. 2005; Bruno \& O’Connor 2005; Duffy \& Hay 2000). Epiphyte communities at Cherokee Sound were dominated by diatoms and chlorophytes, a food source for all dominant amphipod species and less abundant species in this study (Grandidierella bonnieroides (Zimmerman et al. 1979) and A. longimana (Bousfield 1973)).

Despite the reduction of amphipod density in fragmented plots and the removal of amphipods from half the experimental plots, there was no evidence for top-down control of epiphyte biomass or the relative abundance of different phototrophic groups in this study. As such, epiphyte biomass was similar in amphipod control and exclusion plots, and in fragmented and continuous plots, refuting our hypothesis that epiphyte biomass would be higher when amphipods were absent (Table 4.1). Recent research indicates that amphipods fail to reduce the overall biomass of epiphytes, but can alter the community composition of epiphytes on seagrasses (Duffy \& Hay 2000). However, these studies were conducted in mesocosms stocked with locally dominant amphipod species Mesocosms neglect important variables such as immigration, emigration, the importance 
of rare or smaller species, and ecological interactions (e.g., competition and predation), which may impact the epiphyte community composition directly and indirectly. Potential amphipod predators were abundant in our study sites, which could have resulted in an overall reduction of amphipod densities independent of our experimental manipulations. Top-down control of amphipods could reduce grazing pressure on epiphytes resulting in no detectable impact of amphipod grazers on epiphyte abundance and biomass.

Mechanical damage caused by increased boat traffic is likely to increase as coastal development continues (Short et al. 2011; Hallac et al. 2012). As such, studies are needed to address the gaps in our understanding of how propeller scarring will alter the ecological functioning of seagrass ecosystems. This study demonstrates that light to moderate mechanical damage (as defined by Sargent et al. 1995) plays an important role in changing the stoichiometry of seagrass ecosystems. Severely scarred seagrass beds may suffer from depletion of internal nutrient stores and redistribution of amphipods as more and more suitable habitat is lost. The impacts of the scars on amphipod densities could become more apparent over time as seagrass complexity decreases and habitat loss increases (see Walker et al. 1989; Whitfield et al. 2002).

\section{Acknowledgements}

The authors would like to thank Friends of the Environment on Abaco and the residents of Cherokee Sound for logistical assistance. J. L. S. is forever indebted to Sara LeCroy for teaching her the art of amphipod identification; Elizabeth Whitman, A.J. Moss, and Dr. Betsy Stoner for assistance in the field; and Christina Currais and Rebecca 
Valls for assistance in the lab. We would like to thank Dr. Bill Louda at FAU for comments on earlier versions of this manuscript. Special thanks to Mike Bush and Christian Lopes for comments on earlier versions of this manuscript. Financial support was awarded to J. L. S. by the Christina Menendez Fellowship program. 


\section{Tables}

Table 4.1. Predicted and observed responses to habitat fragmentation in seagrass ecosystems from Abaco, Bahamas. $\mathrm{E}=\mathrm{Edge}, \mathrm{I}=$ Interior, and $\mathrm{C}=$ Continuous. Predictions were derived from previous studies on the effects of propeller scarring in seagrass ecosystems, and habitat fragmentation or patch dynamics of gammaridean amphipods.

\begin{tabular}{llc}
\hline Metric & Prediction & Supported (Y) or not (N) \\
\hline 1. Seagrass primary production & Increase at E & $\mathrm{N}$ \\
2. Seagrass nutrient content & Decrease at E & $\mathrm{Y}$ \\
3. Seagrass isotopic content & Increase at E & $\mathrm{Y}$ \\
4. Epiphyte biomass & Decrease in grazer control & $\mathrm{N}$ \\
5. Epiphyte community composition & Change with grazer removal & $\mathrm{N}$ \\
6. Amphipod abundance & Decrease at F plots, E plots & $\mathrm{Y}, \mathrm{N}$ \\
7. Amphipod community composition & Change with fragmentation & $\mathrm{N}$ \\
8. Amphipod grazing & Reduced at E & $\mathrm{N}$ \\
\hline
\end{tabular}


Table 4.2. Table detailing plots and initial models used to test for Fragmentation or Edge Effects. $\mathrm{CS}=$ Cherokee Sound, and JC= Jungle Creek.

\begin{tabular}{lcl}
\hline & Fragmentation Effects & Edge Effects \\
\hline Plots & Continuous and Interior & Interior and Edge \\
Model(s) & Y $\sim$ Site $\times$ Habitat $\times$ Grazer & $\mathrm{Y}_{\mathrm{CS}} \sim$ Habitat $\times$ Grazer \\
& & $\mathrm{Y}_{\mathrm{IC}} \sim$ Habitat $\times$ Grazer \\
\hline
\end{tabular}

*The factor Grazer was removed from the model after the initial run indicated a significant SitexGrazer interaction to test for fragmentation effects in unmanipulated plots. 
Table 4.3. Average values \pm standard error for seagrass percent cover and productivity across treatments at each site. Differences between sites are significantly different for each seagrass metric. $\mathrm{Tt}=$ Thalassia testudinum; $\mathrm{LAI}=\mathrm{Leaf}$ Area Index

\begin{tabular}{lrrrr}
\hline & Units & Cherokee Sound & Jungle Creek & P-value \\
\hline Tt Abundance & $\%$ & $79.7 \pm 2.8$ & $61.7 \pm 3.5$ & $<0.0001$ \\
Short Shoot Density & $\mathrm{Ss} \mathrm{m}^{-2}$ & $789.5 \pm 30.2$ & $519.4 \pm 20.1$ & $<0.0001$ \\
Standing Crop & $\mathrm{g} \mathrm{m}^{-2}$ & $123.7 \pm 8.8$ & $56.5 \pm 4.3$ & $<0.0001$ \\
Leaf Mass per Short Shoot & $\mathrm{mg}$ & $156 \pm 10.1$ & $108.8 \pm 7.1$ & 0.0003 \\
Leaf Length & $\mathrm{mm}$ & $161.2 \pm 7.3$ & $129.5 \pm 4.3$ & 0.0004 \\
Leaf Area & $\mathrm{cm}^{2} \mathrm{ss}^{-1}$ & $38.6 \pm 2.5$ & $26.2 \pm 1.6$ & 0.0001 \\
LAI & $\mathrm{m}^{2} \mathrm{~m}^{-2}$ & $3.1 \pm 0.2$ & $1.4 \pm 0.1$ & $<0.0001$ \\
Areal Productivity & $\mathrm{g} \mathrm{m}^{-2} \mathrm{~d}^{-1}$ & $2.2 \pm 0.2$ & $1.3 \pm 0.2$ & $<0.0001$ \\
Leaf Area Productivity & $\mathrm{cm}^{2} \mathrm{~m}^{-2} \mathrm{~d}^{-1}$ & $487.8 \pm 33.4$ & $274.9 \pm 15.6$ & $<0.0001$ \\
Specific Productivity & $\mathrm{mg} \mathrm{g}^{-1} \mathrm{~d}^{-1}$ & $19.3 \pm 1.4$ & $22.7 \pm 1.1$ & 0.0055 \\
\hline
\end{tabular}


Table 4.4. Minimum, mean and maximum epiphyte biomass by main effect (site, habitat type, and grazer treatment) as described by the epiphyte autotrophic index ( $\mu \mathrm{g} \mathrm{Chl} a \mathrm{~g}^{-1}$ epiphyte dry mass) and leaf specific epiphyte biomass ( $\mu \mathrm{g}$ Chl $a$ leaf area $^{-1}$ ).

\begin{tabular}{|c|c|c|c|c|c|c|c|}
\hline & & \multicolumn{3}{|c|}{ Leaf Specific Epiphyte Biomass } & \multicolumn{3}{|c|}{ Epiphyte Autotrophic Index } \\
\hline \multicolumn{2}{|c|}{ Main Effect } & Min & Mean & Max & Min & Mean & Max \\
\hline \multirow{2}{*}{ Site } & Cherokee Sound & 0.02 & 0.68 & 2.38 & 79.79 & 348.89 & 1439.12 \\
\hline & Jungle Creek & 0.02 & 0.73 & 6.91 & 23.27 & 235.71 & 559.50 \\
\hline \multirow{2}{*}{ Habitat } & Continuous & 0.15 & 0.67 & 2.38 & 60.68 & 293.68 & 703.88 \\
\hline & Fragmented & 0.18 & 0.63 & 1.85 & 143.59 & 288.38 & 483.45 \\
\hline \multirow{2}{*}{ Treatment } & Grazer control & 0.02 & 0.66 & 2.38 & 23.27 & 282.60 & 1439.12 \\
\hline & Grazer exclusion & 0.09 & 0.74 & 6.91 & 27.99 & 302.20 & 663.85 \\
\hline
\end{tabular}




\section{Figure Legends}

Figure 4.1. Map of study area. Black points indicate experimental sites.

Figure 4.2. Schematic of experimental plots. Black shading indicated simulated propeller scar where seagrasses were removed, and grey coloring indicates where seagrasses are intact. Arrows indicate distance between ecotones $(0.25 \mathrm{~m}$ is the width of the scar; $3 \mathrm{~m}$ is the distance from the scar to the patch center) or patch centers $(10 \mathrm{~m})$. Letters indicate where samples were collected: $\mathrm{N}=$ Grazer exclusion; $\mathrm{G}=$ Grazer control; $\mathrm{C}=$ Continuous sample location; I= Interior sample location; $\mathrm{E}=$ Edge sample location; $\mathrm{P}=$ Productivity samples. Figure not drawn to scale.

Figure 4.3. Nitrogen content in seagrass photosynthetic tissues within sites. Differences in nitrogen content by sampling location (panels a and c), and grazer treatments (panels b and $d$ ). $\mathrm{G}=$ grazer control; $\mathrm{NG}=$ grazer exclusion. Significant differences indicated by letters above error bars.

Figure 4.4. Phosphorus content in seagrass photosynthetic tissues within sites. Differences in phosphorus content by sampling location (panels a and c), and grazer treatments (panels b and d). $\mathrm{G}=$ grazer control; $\mathrm{NG}=$ grazer exclusion. Significant differences indicated by letters above error bars.

Figure 4.5. Relationship between $\delta^{13} \mathrm{C}$ and $\%$ phosphorus.

Figure 4.6. Relative abundance of epiphytes by major taxonomic group at each site. $\mathrm{CS}=$ Cherokee Sound, JC= Jungle Creek.

Figure 4.7. Non-metric multidimensional scaling plot illustrating community differences between sites, but not across locations within sites. Jungle Creek plots are indicated by open shapes and Cherokee Sound plots are in solid shapes. Circles are Interior plots, squares are edge plots, and triangles are continuous plots. Codes for amphipod taxa consist of four letters and '+', where Amlo is Ampithoe longimana, Amra is Ampithoe ramondi, Cyco is Cymadusa compta, Cyfi is Cymadusa filosa, Elle is Elasmopus levis, Beun is Bemlos unicornis, Grbo is Grandidierella bonnieroides, Plre is Plesiolembos rectangulatus, Prsc is Protohadzia schoenerae, Nehi is Neomegamphopus hiatus, and Shcu is Shoemakerella cubensis. 
Figures

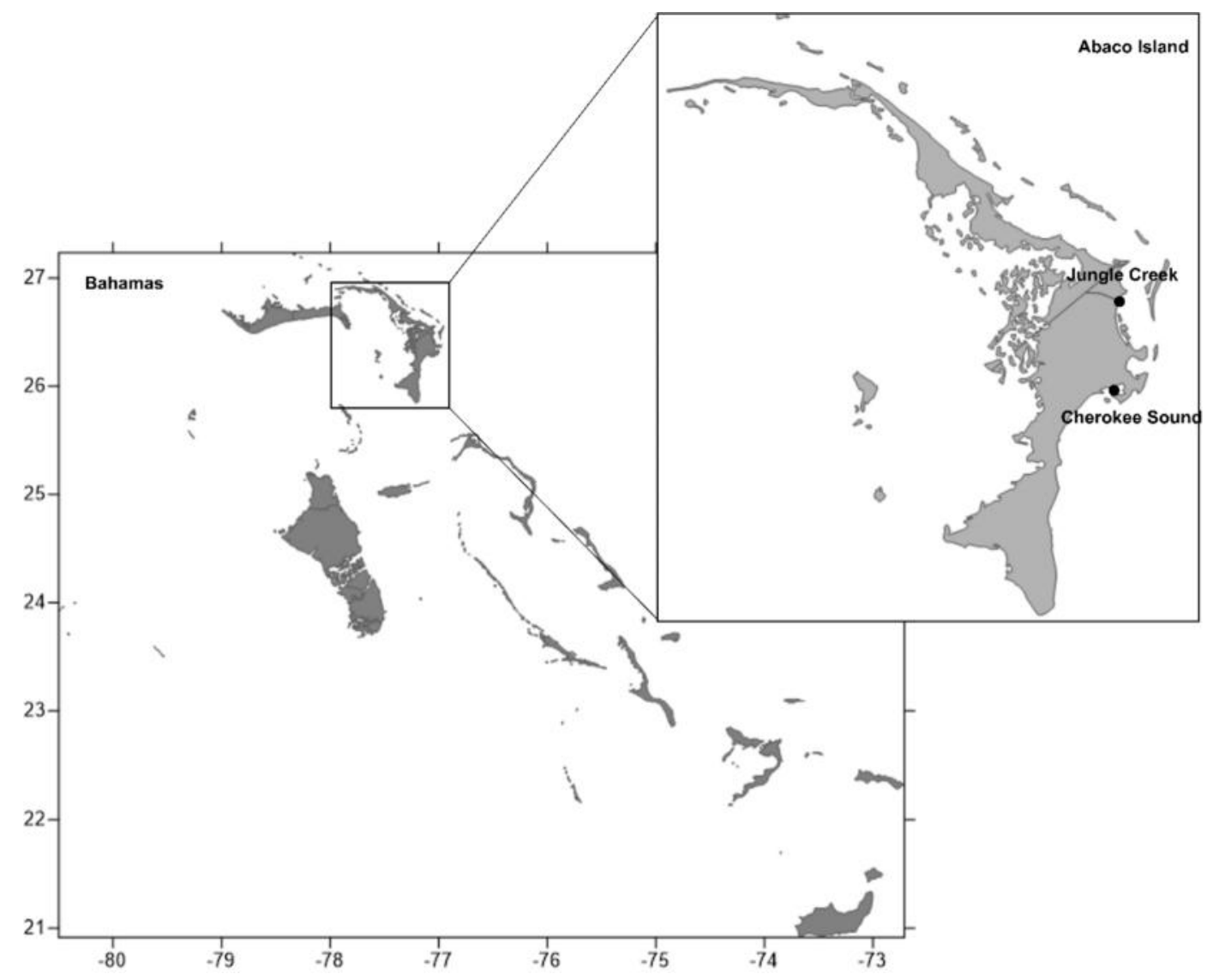

Figure 4.1. Map of study area. Black points indicate experimental sites. 

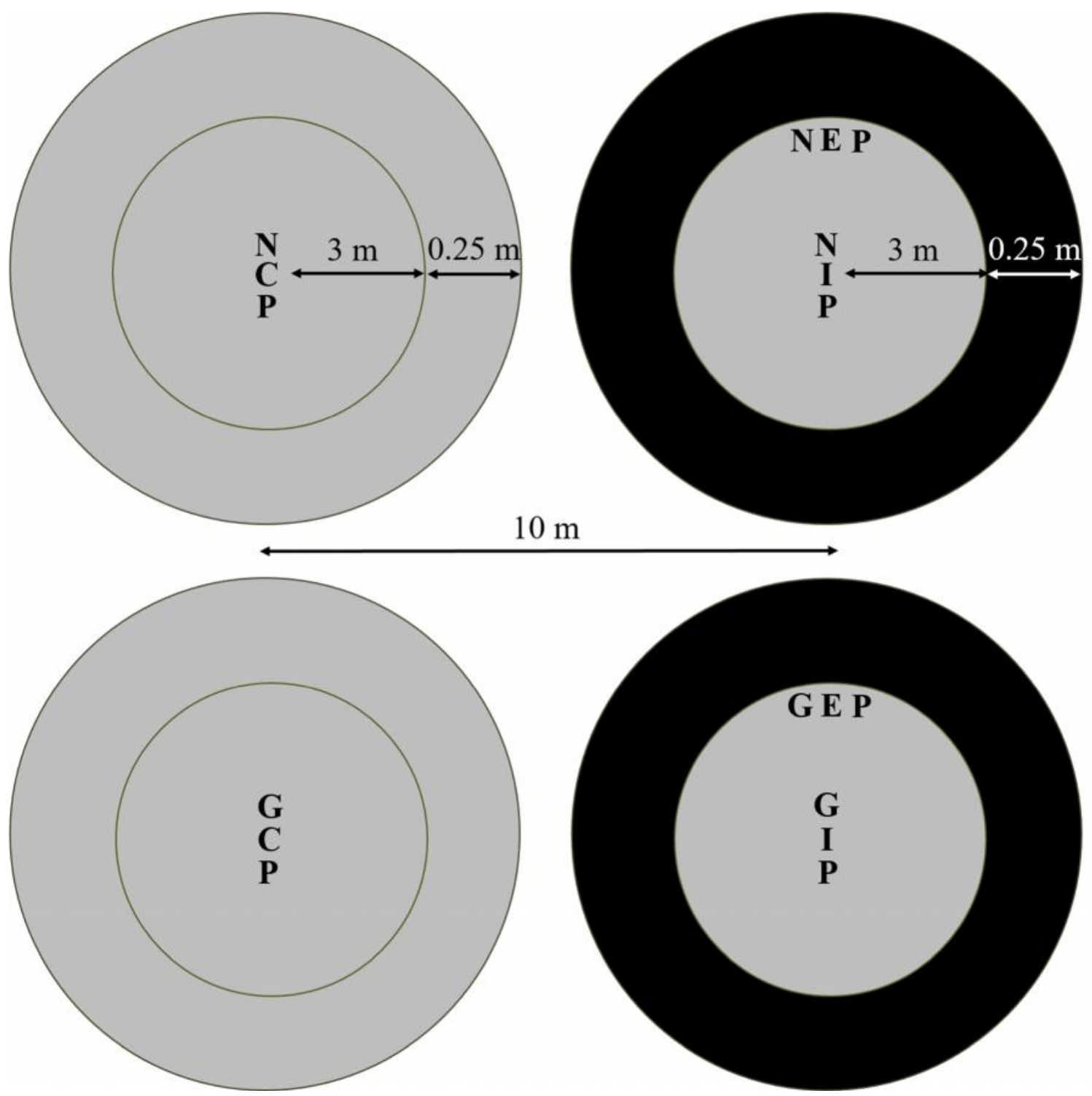

Figure 4.2. Schematic of experimental plots. Black shading indicated simulated propeller scar where seagrasses were removed, and grey coloring indicates where seagrasses are intact. Arrows indicate distance between ecotones $(0.25 \mathrm{~m}$ is the width of the scar; $3 \mathrm{~m}$ is the distance from the scar to the patch center) or patch centers $(10 \mathrm{~m})$. Letters indicate where samples were collected: $\mathrm{N}=$ Grazer exclusion; $\mathrm{G}=$ Grazer control; $\mathrm{C}=\mathrm{Continuous}$ sample location; I= Interior sample location; $\mathrm{E}=$ Edge sample location; $\mathrm{P}=$ Productivity samples. Figure not drawn to scale. 

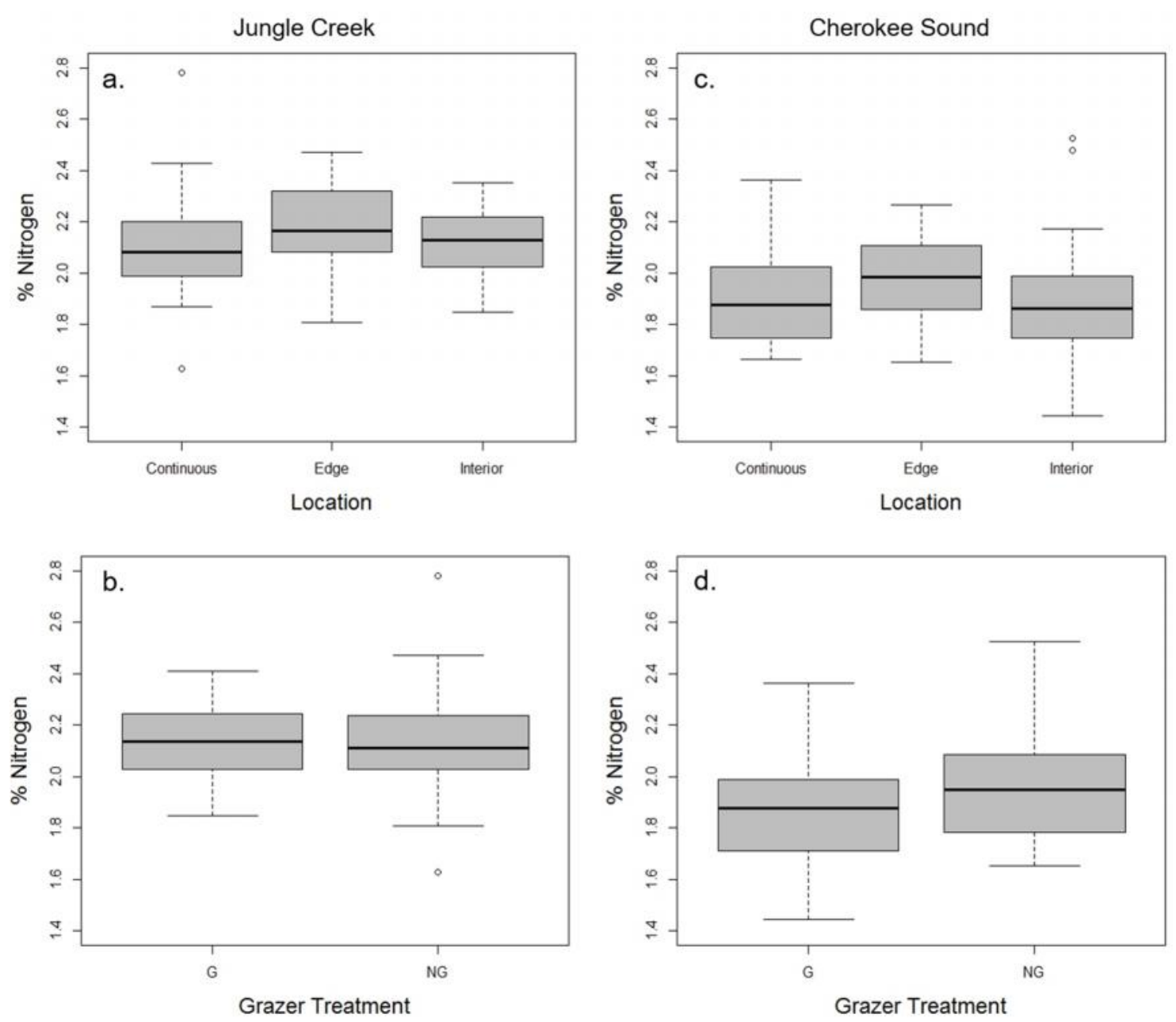

Figure 4.3. Nitrogen content in seagrass photosynthetic tissues within sites. Differences in nitrogen content by sampling location (panels a and c), and grazer treatments (panels b and d). $\mathrm{G}=$ grazer control; $\mathrm{NG}=$ grazer exclusion. Significant differences indicated by letters above error bars. 

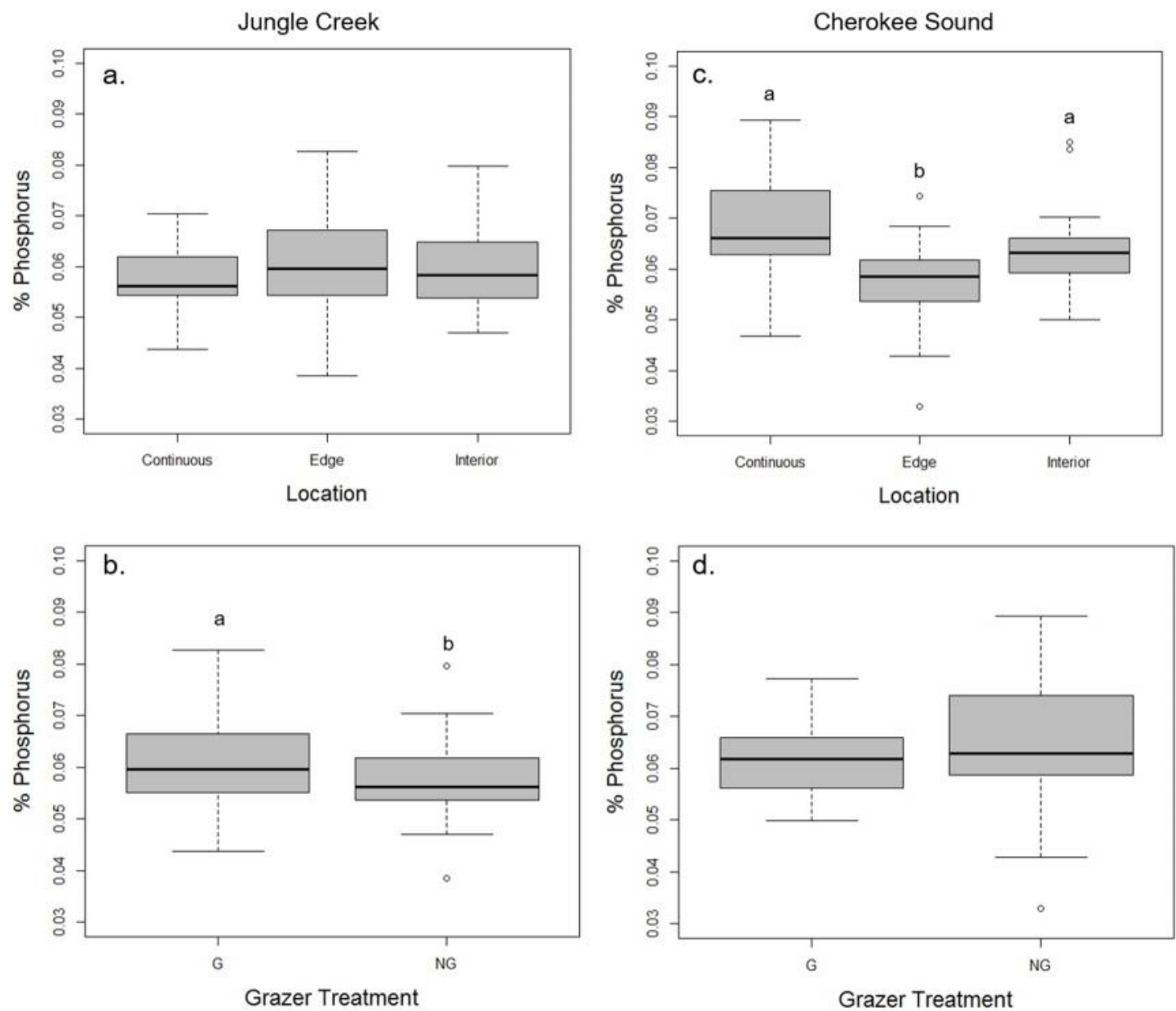

Figure 4.4. Phosphorus content in seagrass photosynthetic tissues within sites. Differences in phosphorus content by sampling location (panels a and c), and grazer treatments (panels $b$ and $d$ ). $\mathrm{G}=$ grazer control; $\mathrm{NG}=$ grazer exclusion. Significant differences indicated by letters above error bars. 


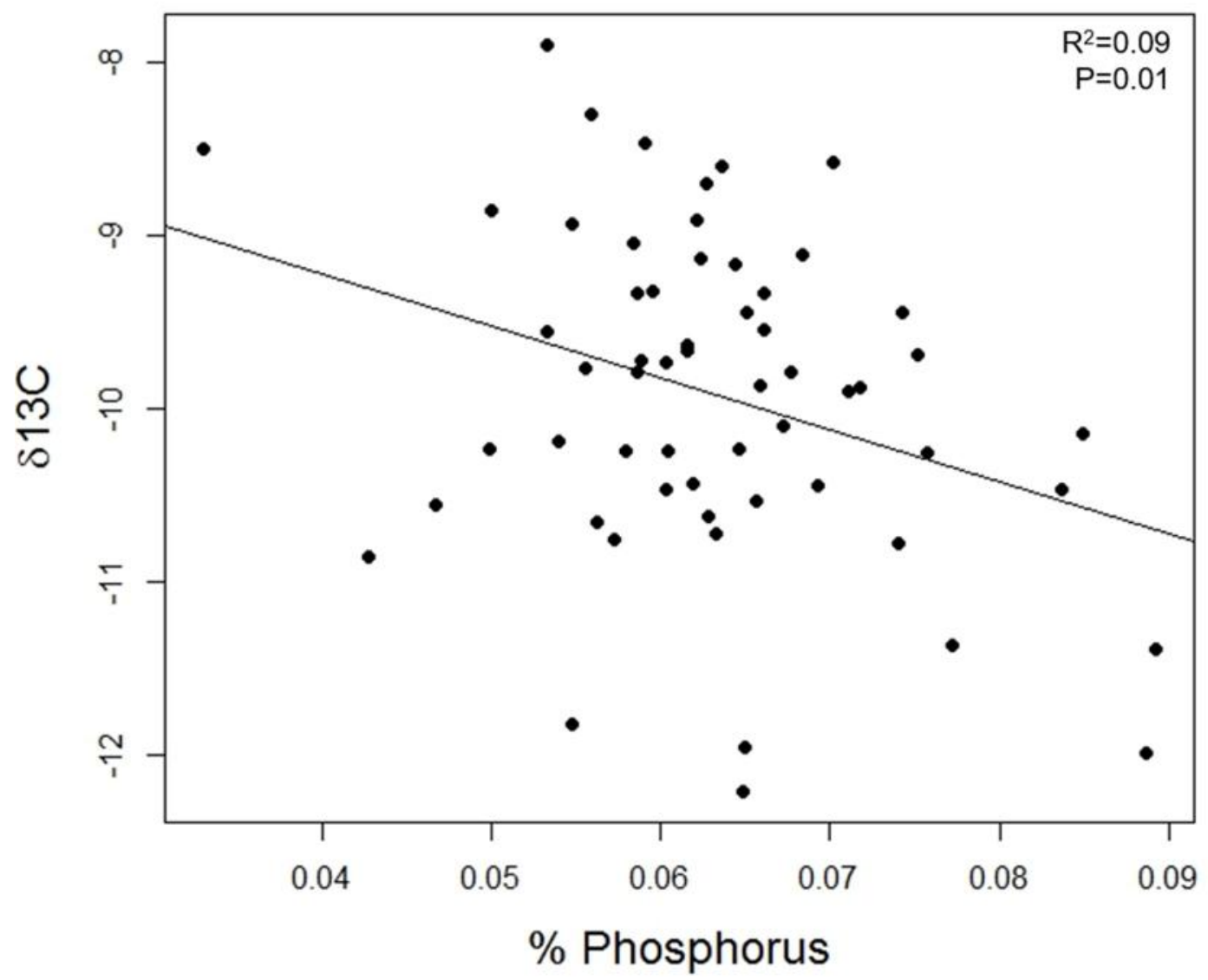

Figure 4.5. Relationship between $\delta^{13} \mathrm{C}$ and $\%$ phosphorus. 


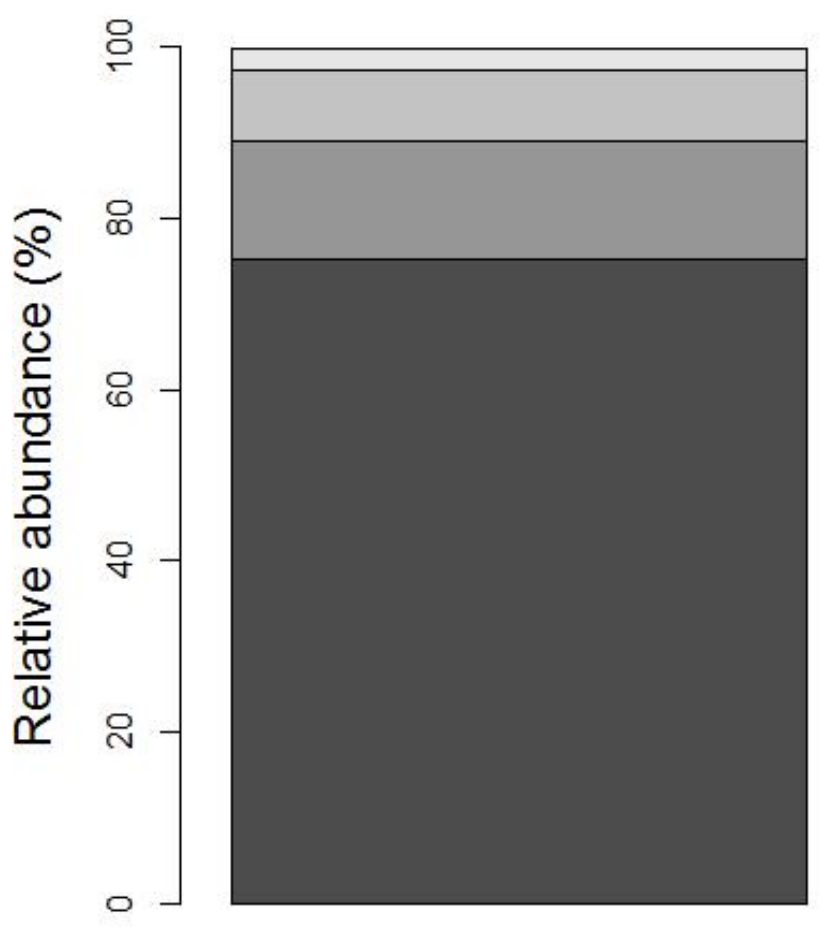

CS

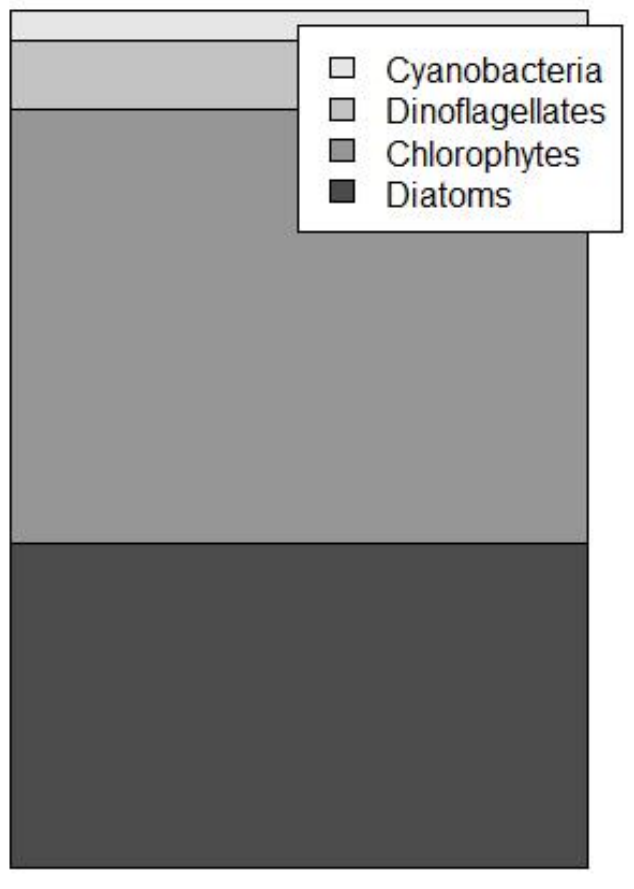

JC

Site

Figure 4.6. Relative abundance of epiphytes by major taxonomic group at each site. $\mathrm{CS}=$ Cherokee Sound, JC= Jungle Creek. 


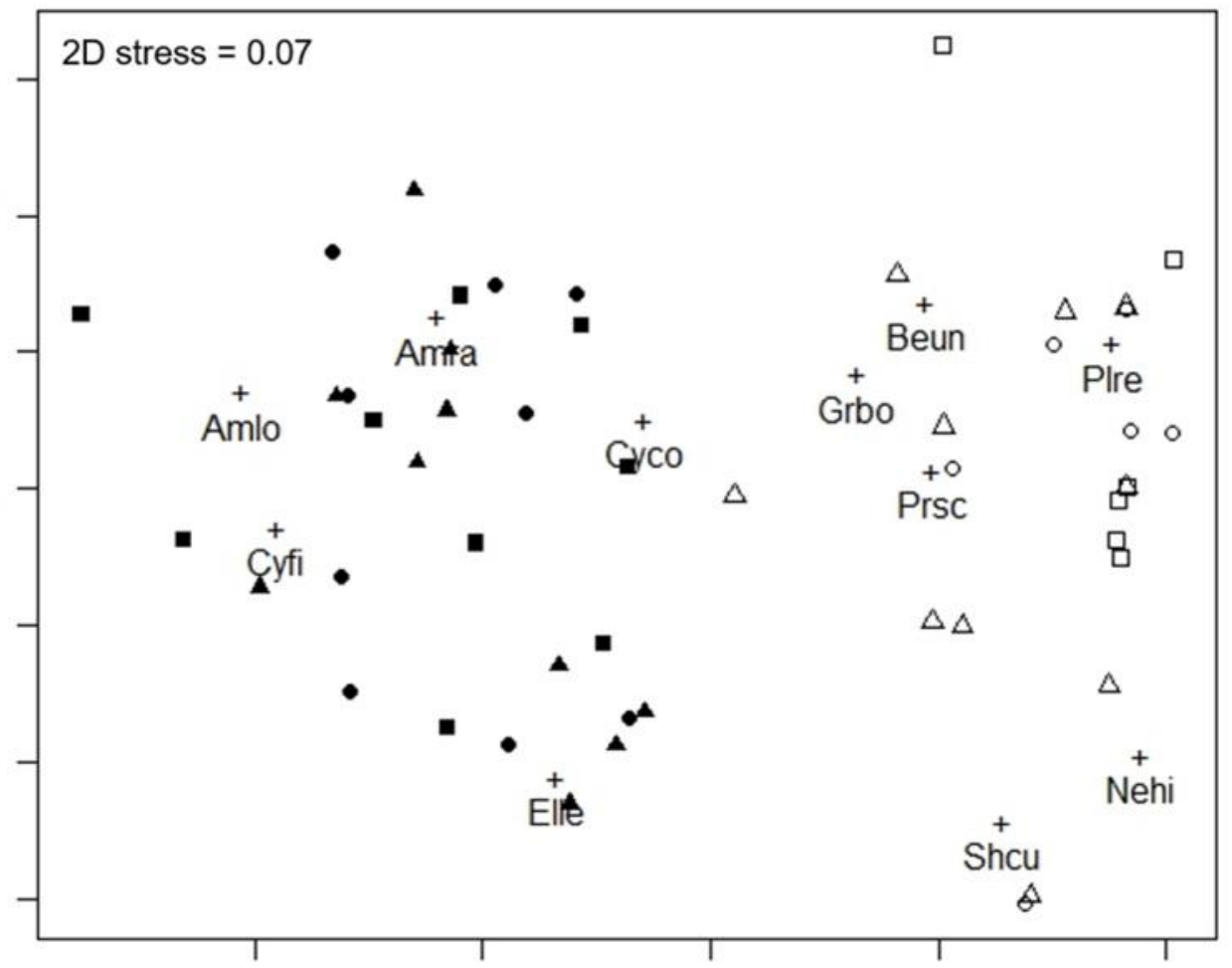

Figure 4.7. Non-metric multidimensional scaling plot illustrating community differences between sites, but not across locations within sites. Jungle Creek plots are indicated by open shapes and Cherokee Sound plots are in solid shapes. Circles are Interior plots, squares are edge plots, and triangles are continuous plots. Codes for amphipod taxa consist of four letters and ' + ', where Amlo is Ampithoe longimana, Amra is Ampithoe ramondi, Cyco is Cymadusa compta, Cyfi is Cymadusa filosa, Elle is Elasmopus levis, Beun is Bemlos unicornis, Grbo is Grandidierella bonnieroides, Plre is Plesiolembos rectangulatus, Prsc is Protohadzia schoenerae, Nehi is Neomegamphopus hiatus, and Shcu is Shoemakerella cubensis. 


\section{References}

Abal, E.G., Loneragan, N., Bowen, P., Perry, C.J., Udy, J.W., Dennison, W.C., 1994. Physiological and morphological responses of the seagrass Zostera capricorni Aschers, to light intensity. J. Exp. Mar. Bio. Ecol. 178, 113-129. doi:10.1016/00220981(94)90228-3

Allgeier, J.E., Rosemond, A.D., Mehring, A.S., Layman, C.A., 2010. Synergistic nutrient colimitation across a gradient of ecosystem fragmentation in subtropical mangrovedominated wetlands. Limnol. Oceanogr. 55, 2660-2668.

doi:10.4319/lo.2010.55.6.2660

Armbrust, K.L., Crosby, D.G., 1991. Fate of carbaryl, 1-naphthol, and atrazine in seawater. Pac. Sci. 45, 314-320.

Armitage, A.R., Frankovich, T. a., Fourqurean, J.W., 2006. Variable responses within epiphytic and benthic microalgal communities to nutrient enrichment. Hydrobiologia 569, 423-435. doi:10.1007/s10750-006-0146-8

Armitage, A.R., Frankovich, T.A., Heck, K.L., Fourqurean, J.W., 2005. Experimental nutrient enrichment causes complex changes in seagrass, microalgae, and macroalgae community structure in Florida Bay. Estuaries 28, 422-434. doi:10.1007/BF02693924

Arponen, H., Boström, C., 2012. Responses of mobile epifauna to small-scale seagrass patchiness: is fragmentation important? Hydrobiologia 680, 1-10. doi:10.1007/s10750-011-0895-X

Bell, S.S., Brooks, R.A., Robbins, B.D., Fonseca, M.S., Hall, M.O., 2001. Faunal response to fragmentation in seagrass habitats: implications for seagrass conservation. Biol. Conserv. 100, 115-123.

Bell, S.S., Hall, M.O., Soffian, S., Madley, K., 2002. Assessing the impact of boat propeller scars on fish and shrimp utilizing seagrass beds. Ecol. Appl. 12, 206-217.

Bologna, P.A.X., Heck Jr., K.L., 1999. Macrofaunal associations with seagrass epiphytes relative importance of trophic and structural characteristics. J. Exp. Mar. Bio. Ecol. 242, 21-39.

Bologna, P.A.X., Heck, K.L., 2002. Impact of habitat edges on density and secondary production of seagrass-associated fauna. Estuaries 25, 1033-1044. doi:10.1007/BF02691350

Bousfield, E.L., 1973. Shallow-Water Gammaridean Amphipoda of New England. Cornell University Press. 
Brawley, S.H. \& Adey, W.H. (1981) The effect of micrograzers on algal community structure in a coral reef microcosm. Mar. Biol., 61, 167-177.

Brook, I.M., 1977. Trophic Relationships in a Seagrass Community (Thalassia testudinum), in Card Sound, Florida. Fish Diets in Relation to Macrobenthic and Cryptic Faunal Abundance. Trans. Am. Fish. Soc. 106, 219-229. doi:10.1577/15488659(1977)106<219:TRIASC > 2.0.CO;2

Bruno, J.F., O'Connor, M.I., 2005. Cascading effects of predator diversity and omnivory in a marine food web. Ecol. Lett. 8, 1048-1056. doi:10.1111/j.14610248.2005.00808.x

Buza-Jacobucci, G., Pereira-Leite, F., 2014. The role of epiphytic algae and different species of Sargassum in the distribution and feeding of herbivorous amphipods. Lat. Am. J. Aquat. Res. 42, 353-363.

Campbell, J., Fourqurean, J., 2009. Interspecific variation in the elemental and stable isotope content of seagrasses in South Florida. Mar. Ecol. Prog. Ser. 387, 109-123. doi: $10.3354 /$ meps08093

Carpenter, R.C., 1986. Partitioning Herbivory and Its Effects on Coral Reef Algal Communities. Ecol. Monogr. 56, 345. doi:10.2307/1942551

Ceh, J., Molis, M., Dzeha, T.M., Wahl, M., 2005. Induction and reduction of antiherbivore defenses in brown and red macroalgae off the Kenyan coast. J. Phycol. 41, 726-731. doi:10.1111/j.1529-8817.2005.00093.x

Cook, K., Vanderklift, M.A., Poore, A.G.B., 2011. Strong effects of herbivorous amphipods on epiphyte biomass in a temperate seagrass meadow. Mar. Ecol. Prog. Ser. 443, 263-269.

Douglass, J.G., Duffy, J.E., Bruno, J.F., 2008. Herbivore and predator diversity interactively affect ecosystem properties in an experimental marine community. Ecol. Lett. 11, 598-608. doi:10.1111/j.1461-0248.2008.01175.x

Duffy, J.E., Harvilicz, A.M., 2001. Species-specific impacts of grazing amphipods in an eelgrass-bed community. Mar. Ecol. Prog. Ser. 223, 201-211.

Duffy, J.E., Hay, M.E., 1994. Herbivore resistance to seaweed chemical defense: The roles of mobility and predation risk. Ecol. 75, 1304-1319.

Duffy, J.E., Hay, M.E., 2000. Strong impacts of grazing amphipods on the organization of a benthic community. Ecol. Modell. 70, 237-263. 
Duffy, J.E., Reynolds, P.L., Boström, C., Coyer, J.A., Cusson, M., Donadi, S., Douglass, J.G., Eklöf, J.S., Engelen, A.H., Eriksson, B.K., Fredriksen, S., Gamfeldt, L., Gustafsson, C., Hoarau, G., Hori, M., Hovel, K., Iken, K., Lefcheck, J.S., Moksnes, P.-O., Nakaoka, M., O’Connor, M.I., Olsen, J.L., Richardson, J.P., Ruesink, J.L., Sotka, E.E., Thormar, J., Whalen, M.A., Stachowicz, J.J., 2015. Biodiversity mediates top-down control in eelgrass ecosystems: a global comparativeexperimental approach. Ecol. Lett. 18, 696-705. doi:10.1111/ele.12448

Dumbauld, B.R., Brooks, K.M., Posey, M.H., 2001. Response of an estuarine benthic community to application of the pesticide carbaryl and cultivation of Pacific Oysters (Crassostrea gigas) in Willapa Bay, Washington. Mar. Pollut. Bull. 42, 826-844. doi:10.1016/S0025-326X(00)00230-7

Durako, M.J. \& Hall, M.O. (1992) Effects of light on the stable carbon isotope composition of the seagrass Thalassia testudinum. Mar. Ecol. Prog. Ser., 86, 99-101

Eggleston, D.B., Elis, W.E., Etherington, L.L., Dahlgren, C.P., Posey, M.H., 1999. Organism responses to habitat fragmentation and diversity: Habitat colonization by estuarine macrofauna. J. Exp. Mar. Bio. Ecol. 236, 107-132. doi:10.1016/S00220981(98)00192-0

Fahrig, L., 2003. Fragmentation on of habitat effects biodiversity. Annu. Rev. Ecol. Evol. Syst. 34, 487-515. doi:10.1146/132419

Fonseca, M.S., Kenworthy, W.J., Thayer, G.W., 1998. Guidelines for the conservation and restoration of seagrasses in the United States and adjacent waters. NOAA Coastal Ocean Program: Decision Analysis Series vol. 12. Beaufort, NC.

Fourqurean, J.W., Muth, M.F., Boyer, J.N., 2010. Epiphyte loads on seagrasses and microphytobenthos abundance are not reliable indicators of nutrient availability in oligotrophic coastal ecosystems. Mar. Pollut. Bull. 60, 971-83. doi:10.1016/j.marpolbul.2010.03.003

Fourqurean, J.W., Willsie, A., Rose, C.D., Rutten, L.M., 2001. Spatial and temporal pattern in seagrass community composition and productivity in south Florida. Mar. Biol. 138, 341-354. doi:10.1007/s002270000448

Fourqurean, J.W., Zieman, J.C., 1992. Phosphorus limitation of primary production in Florida Bay: Evidence from C:N:P ratios of the dominant seagrass Thalassia testudinum. Limnol. Oceanogr. 37, 162-171.

Fox, J.W., Weisberg, S., 2011. An $\{\mathrm{R}\}$ companion to applied regression, 2nd ed. Sage, Thousand Oaks, CA. 
Frankovich, T.A., Armitage, A.R., Wachnicka, A.H., Gaiser, E.E., Fourqurean, J.W., 2009. Nutrient Effects on Seagrass Epiphyte Community Structure in Florida Bay. J. Phycol. 45, 1010-1020. doi:10.1111/j.1529-8817.2009.00745.x

Hagerthey, S.E., William Louda, J., Mongkronsri, P., 2006. Evaluation of pigment extraction methods and a recommended protocol for periphyton chlorophyll $a$ determination and chemotaxonomic assessment. J. Phycol. 42, 1125-1136. doi:10.1111/j.1529-8817.2006.00257.x

Hallac, D.E., Sadle, J., Pearlstine, L., Herling, F., Shinde, D., 2012. Boating impacts to seagrass in Florida Bay, Everglades National Park, Florida, USA: links with physical and visitor-use factors and implications for management. Mar. Freshw. Res. 63, 1117. doi:10.1071/MF12025

Healey, D., Hovel, K.A., 2004. Seagrass bed patchiness: Effects on epifaunal communities in San Diego Bay, USA. J. Exp. Mar. Bio. Ecol. 313, 155-174. doi:10.1016/j.jembe.2004.08.002

Heck, K.L., Pennock, J.R., Valentine, J.F., Coen, L.D., Sklenar, S.A., 2000. Effects of nutrient enrichment and small predator density on seagrass ecosystems : An experimental assessment. Limnol. Oceanogr. 45, 1041-1057.

Holmquist, J.G., 1994. Benthic macroalgae as a dispersal mechanism for fauna: influence of a marine tumbleweed. J. Exp. Mar. Bio. Ecol. 180, 235-251. doi:10.1016/00220981(94)90069-8

Hothorn, T., Bretz, F., \& Westfall, P. (2008). Simultaneous inference in general parametric models. Biometrical J 50(3), 346--363.

Høy, T., Horsberg, T.E., Wichstrøm, R., 1991. Inhibition of acetylcholinesterase in rainbow trout following dichlorvos treatment at different water oxygen levels. Aquaculture 95, 33-40. doi:10.1016/0044-8486(91)90070-N

Hughes, A., Bando, K., Rodriguez, L., Williams, S., 2004. Relative effects of grazers and nutrients on seagrasses: a meta-analysis approach. Mar. Ecol. Prog. Ser. 282, 87-99. doi:10.3354/meps 282087

Irlandi, E.A., 1994. Large- and small-scale effects of habitat structure on rates of predation: how percent coverage of seagrass affects rates of predation and siphon nipping on an infaunal bivalve. Oecologia 98, 176-183. doi:10.1007/BF00341470

Jaschinski, S., Sommer, U., 2008. Functional diversity of mesograzers in an eelgrassepiphyte system. Mar. Biol. 154, 475-482. doi:10.1007/s00227-008-0942-y 
Kenworthy, W.J., Fonseca, M.S., Whitfield, P.E., Hammerstrom, K.K., 2002. Analysis of seagrass Recovery in Experimental excavations and propeller-scar Disturbances in the Florida Keys National Marine Sanctuary. J. Coast. Res. URL http://www.jstor.org/stable/25736344?seq=1\#page_scan_tab_contents (accessed 1.26.16).

Laurance, W.F., Lovejoy, T.E., Vasconcelos, H.L., Bruna, E.M., Didham, R.K., Stouffer, P.C., Gascon, C., Bierregaard, R.O., Laurance, S.G., Sampaio, E., 2002. Ecosystem decay of Amazonian forest fragments: a 22-year investigation. Conserv. Biol. 16, 605-618. doi:10.1046/j.1523-1739.2002.01025.x

Lecroy, S.E., 2002. An illustrated identification guide to the nearshore marine and estuarine gammaridean amphipoda of Florida. Tallahassee.

Lefcheck, J.S., Marion, S.R., Lombana, A. V, Orth, R.J., 2016. Faunal communities are invariant to fragmentation in experimental seagrass landscapes.

doi:10.7287/peerj.preprints.1823v1

Louda, J.W., Li, J., Liu, L., Winfree, M.N., Baker, E.W., 1998. Chlorophyll-a degradation during cellular senescence and death. Org. Geochem. 29, 1233-1251. doi:10.1016/S0146-6380(98)00186-7

McSkimming, C., Tanner, J.E., Russell, B.D., Connell, S.D., 2015. Compensation of nutrient pollution by herbivores in seagrass meadows. J. Exp. Mar. Bio. Ecol. 471, 112-118. doi:10.1016/j.jembe.2015.05.018

Neckles, H.A., Wetzel, R.L., Orth, R.J., 1993. Relative effects of nutrient enrichment and grazing on epiphyte macrophyte dynamics. Oecologia 93, 285-295.

Oksanen, J., Guillaume Blanchet, F., Kindg, R., Legendre, P., Minchin, P. R., O'Hara, R. B., Simpson, G. L., Solymos, P., Henry, M., Stevens, H., \& Wagner, H. (2015). vegan: Community Ecology Package. R package version 2.3-2. http://CRAN.Rproject=vegan

Orth, R.J., van Montfrans, J., 1984. Epiphyte-seagrass relationships with an emphasis on the role of micrograzing: a review. Aquat. Bot. 18, 43-69.

Peterson, B.J., Thompson, K.R., Cowan Jr., J.H., Heck Jr., K.L., 2001. Comparison of predation pressure in temperate and subtropical seagrass habitats based on chronographic tethering. Mar. Ecol. Prog. Ser. 224, 77-85.

Pierri-Daunt, A.B., Tanaka, M.O., 2014. Assessing habitat fragmentation on marine epifaunal macroinvertebrate communities: an experimental approach. Landsc. Ecol. 29, 17-28. doi:10.1007/s10980-013-9970-1 
Pinheiro, J., Bates, D., DebRoy, S., Sarkar, D., \& R Core Team (2015). nlme: Linear and Nonlinear Mixed Effects Models. R package version 3.1-120, URL: http://CRAN.Rproject.org/package=nlme.

Poore, A.G.B., Campbell, A.H., Steinberg, P.D., 2009. Natural densities of mesograzers fail to limit growth of macroalgae or their epiphytes in a temperate algal bed. J. Ecol. 97, 164-175. doi:10.1111/j.1365-2745.2008.01457.x

R Core Team 2015. R: A language and environment for statistical computing. $\mathrm{R}$ Foundation for Statistical Computing, Vienna, Austria. URL http://www.Rproject.org/.

Reed, B.J., Hovel, K.A., 2006. Seagrass habitat disturbance: how loss and fragmentation of eelgrass Zostera marina ingludnces epifaunal abundance and diversity. Mar. Ecol. Prog. Ser. 326, 133-143.

Ries, L., Sisk, T.D., 2008. A predictive model of edge effects. Ecol. 85, 2917-2926,

Rooker, J.R., 1995. Feeding Ecology of the Schoolmaster Snapper, Lutjanus apodus (Walbaum), from Southwestern Puerto Rico. Bull. Mar. Sci.56, 881-894

Roth, M., Richards, R.H., Sommerville, C., 1993. Current practices in the chemotherapeutic control of sea lice infestations in aquaculture: a review. J. Fish Dis. 16, 1-26. doi:10.1111/j.1365-2761.1993.tb00844.x

Sargent, F.J., Leary, T.J., Crewz, D.W., Kruer, C.R., 1995. Scarring of Florida's Seagrasses: assessment and management options.

Schneider, F.I., Mann, K.H., 1991. Species specific relationships of invertebrates to vegetation in a seagrass bed. II. Experiments on the importance of macrophyte shape, epiphyte cover and predation. J. Exp. Mar. Bio. Ecol. 145, 119-139. doi:10.1016/0022-0981(91)90009-L

Short, F.T., Polidoro, B., Livingstone, S.R., Carpenter, K.E., Bandeira, S., Bujang, J.S., Calumpong, H.P., Carruthers, T.J.B., Coles, R.G., Dennison, W.C., Erftemeijer, P.L.A., Fortes, M.D., Freeman, A.S., Jagtap, T.G., Kamal, A.H.M., Kendrick, G.A., Judson Kenworthy, W., La Nafie, Y.A., Nasution, I.M., Orth, R.J., Prathep, A., Sanciangco, J.C., Tussenbroek, B. van, Vergara, S.G., Waycott, M., Zieman, J.C., 2011. Extinction risk assessment of the world's seagrass species. Biol. Conserv. 144, 1961-1971. doi:10.1016/j.biocon.2011.04.010

Spivak, A.C., Canuel, E.A., Duffy, J.E., Richardson, J.P., 2009. Nutrient enrichment and food web composition affect ecosystem metabolism in an experimental seagrass habitat. PLoS One 4, e7473. doi:10.1371/journal.pone.0007473 
Stoner, E.W., Layman, C.A, Yeager, L.A, Hassett, H.M., 2011. Effects of anthropogenic disturbance on the abundance and size of epibenthic jellyfish Cassiopea spp. Mar. Pollut. Bull. 62, 1109-14. doi:10.1016/j.marpolbul.2011.03.023

Tanner, J.E., 2005. Edge effects on fauna in fragmented seagrass meadows. Austral Ecol. 30, 210-218. doi:10.1111/j.1442-9993.2005.01438.x

Tanner, J.E., 2003. Patch shape and orientation influences on seagrass epifauna are mediated by dispersal abilities. Oikos 100, 517-524. doi:10.1034/j.16000706.2003.12060.x

Tomlin, C.D. S. 2000. The Pesticide Manual. 12th Ed. British Crop Protection Council. Surrey, UK. pp. 133-134.

Turner, M.G., Gardner, R.H., O’Neill, R.V., 2001. Landscape ecology in theory and practice: pattern and process. Springer-Verlag, New York

Uhrin, A., Holmquist, J., 2003. Effects of propeller scarring on macrofaunal use of the seagrass Thalassia testudinum. Mar. Ecol. Prog. Ser. 250, 61-70.

doi:10.3354/meps 250061

Venables, W. N. \& Ripley, B. D. (2002) Modern Applied Statistics with S. $4^{\text {th }}$ Ed. Springer, NewYork. ISBN 0-387-95457-0

Virnstein, R.W., Curran, M.C., 1986. Colonization of artificial seagrass versus time and distance from source. Mar. Ecol. Prog. Ser. 29, 279-288.

Virnstein, R.W., Howard, R.K., 1987. Motile epifauna of marine macrophytes in the Indian River Lagoon, Florida. I. Comparisons among three species of seagrasses from adjacent beds. Bull. Mar. Sci. 41, 1-12.

Walker, D.I., Lukatelich, R.J., Bastyan, G., McComb, A.J., 1989. Effect of boat moorings on seagrass beds near Perth, Western Australia. Aquat. Bot. 36, 69-77. doi:10.1016/0304-3770(89)90092-2

Waycott, M., Duarte, C.M., Carruthers, T.J.B., Orth, R.J., Dennison, W.C., Olyarnik, S., Calladine, A., Fourqurean, J.W., Heck Jr., K.L., Hughes, A.R., Kendrick, G.A., Kenworthy, W.J., Short, F.T., Williams, S.L., 2009. Accelerating loss of seagrasses across the globe threatens coastal ecosystems. Proc. Natl. Acad. Sci. 106, 1237712381.

Whalen, M.A., Duffy, J.E., Grace, J.B., 2013. Temporal shifts in top-down versus bottom-up control of epiphytic algae in a seagrass ecosystem. Ecology 94, 510-520. doi:10.1890/12-0156.1 
Young, D.K., 1978. Regulation of species densities of seagrass-associated macrobenthos: evidence from field experiments in the Indian River estuary, Florida. J. Mar. Res. 36, 569-593.

Zieman, J.C., 1976. The ecological effects of physical damage from motor boats on turtle grass beds in Southern Florida. Aquat. Bot. 2, 127-139. doi:10.1016/03043770(76)90015-2

Zimmerman, R., Gibson, R., Harrington, J., 1979. Herbivory and detritivory among gammaridean amphipods from a Florida seagrass community. Mar. Biol. 54, 41-47. doi:10.1007/BF00387050 
CHAPTER V

\section{CONCLUSIONS AND FUTURE DIRECTIONS}


Anthropogenic disturbance is ubiquitous, impacting even the most remote ecosystems. As such, monitoring programs have become a necessary component to the conservation of terrestrial, aquatic, and marine ecosystems worldwide. Major goals of monitoring programs are to adequately sample a habitat that maximizes the information being gathered while minimizing the destructive impacts of and costs associated with sampling (Thomas 1993; Fourqurean \& Rutten 2003). Incorporating species that can be indicators of changing ecosystem conditions can make monitoring programs more effective in assessing the overall health and functioning of an ecosystem (Thomas 1993).

Amphipods are widely used as indicators in temperate ecosystems where longterm natural history and taxonomic information exist, but are not widely used in tropical ecosystems (Thomas 1993). This dissertation is the first to study the broad-scale spatial distribution of amphipod communities, and identify the relationship between amphipod community composition, species richness and diversity, and site-specific environmental climates in a sub-tropical ecosystem. Baseline data collected as part of this body of research can be used to justify incorporating amphipod sampling into monitoring programs in south Florida and similar sub-tropical ecosystems.

To determine if amphipods would be indicators of changes in environmental conditions, I studied the spatial and temporal distribution of marine gammaridean amphipods in south Florida. In Chapter II, I identified amphipods at 15 sites across the Florida Keys National Marine Sanctuary, Florida Bay, and Dry Tortugas National Park. From these data I identified environmental drivers of amphipod community composition, density, species richness, and diversity. In south Florida, amphipod communities are largely driven by habitat complexity (macrophyte biomass), food availability (epiphyte 
abundance) and factors that vary seasonally (dissolved oxygen and temperature), nitrogen concentration in the water-column, and factors associated with hardbottom habitats (high macroalgal diversity and low seagrass density). These environmental factors can vary with anthropogenic influences. Different types of disturbance, including changes in water quality can influence both macrophyte and epiphyte communities, as well as nitrogen concentrations in the water column. Changes in the complexity of amphipod habitats (macrophyte biomass and species composition) and the quantity and quality of their food source (epiphyte biomass and nutrient content) can potentially alter the distribution of amphipods (see Stoner 1980, Reed \& Hovel 2006, Cruz-Rivera \& Hay 2000, Duarte et al. 2010). This work is the first assessment of amphipod community structure across south Florida and the relationship with local environmental climates. These baseline data can be used for future comparisons of amphipod community structure to better understand their spatial and temporal distribution and the factors driving the variation in amphipod communities.

For amphipods to be incorporated as bioindicators into seagrass monitoring programs, a solid understanding of the spatial and temporal variability in their community structure is necessary in order to distinguish between natural variation and variation as a result of anthropogenic changes (Noss 1990). Building on Chapter II, Chapter III investigated the temporal variability in amphipod community structure in Florida Bay. I found that amphipod communities in Florida Bay exhibit site-specific temporal variability. Variation in amphipod communities was largely driven by macrophyte density, nitrogen concentration, and freshwater input. Results from Chapters II and III indicate that there is a relationship between environmental variables and 
amphipod community structure, but more information is needed to fully understand the extent of temporal variability.

Seagrass beds and gammaridean amphipods are not only impacted by chemical pollutants (e.g., nutrients, toxicants), but are also impacted by mechanical damage from boat propellers, dredging, fishing practices, and trampling (Barnard 1958; Barnard 1961; Short et al. 2011). In Chapter IV, I simulated propellers scars in a continuous seagrass bed to investigate the impacts of propeller scarring on seagrass ecosystem functioning. I found that fragmentation of seagrass habitats as a result of boat propeller scars altered seagrass nutrient stores and reduced amphipod density, but did not impact the ability of amphipods to remove epiphytic algae from seagrass leaves. While propeller scarring does impact seagrass and amphipod communities, there was little impact on the overall functioning of the ecosystem. The reduction of amphipod densities in seagrass patches fragmented by propeller scarring could provide preliminary evidence that amphipods could be used as ecological indicators. More work is needed to investigate the impact of amphipod reduction in fragmented plots on higher trophic levels.

All chapters provide support that gammaridean amphipods would be good indicators of changes in environmental conditions in sub-tropical seagrass beds. Not only does this research increase our knowledge of the factors regulating amphipod community structure, it has contributed to the understanding of the utility of amphipods as environmental indicators in sub-tropical ecosystems. Amphipod samples are inexpensive to collect in existing monitoring programs and are ecologically relevant species that accumulate pollutants and have predictable responses to changes in some environmental variables (e.g., Rainbow \& White 1989). However, more temporal data are needed to 
better understand the factors regulating amphipod community structure so managers can distinguish between the natural phenology of amphipods and the responses of amphipods to anthropogenic disturbances in south Florida (see McGeoch 2007, and Rainio \& Niemelä 2003). As such, I recommend increasing the spatial and temporal extent of amphipod sampling and maintaining sample collection as part of the existing seagrass monitoring programs. This work will be increasingly valuable as increasing human populations and Everglades restoration continue to influence south Florida marine ecosystems. Furthermore, the results of this dissertation are applicable to management efforts in seagrass habitats in other tropical ecosystems. 


\section{References}

Barnard, J. L. (1958) Amphipod crustaceans as fouling organisms in Los Angeles-Long Beach harbors, with reference to the influence of seawater turbidity, California Fish and Game,44, 161-170.

Barnard, J. L. (1961) Relationship of California amphipod faunas in Newport Bay and in the open sea, Pacific Naturalist, 2, 166-186.

Cruz-Rivera E, Hay ME. 2000. Can quantity replace quality? Food choice, compensatory feeding, and fitness of marine mesograzers. Ecology 81: 201-219.

Duarte C, Navarro JM, Acuña K, Gómez I. 2010. Feeding preferences of the sandhopper Orchestoidea tuberculata: the importance of algal traits. Hydrobiologia 651: 291303.

Fourqurean, J.W. \& Rutten L.M. (2003). Competing goals of spatial and temporal resolution: monitoring seagrass communities on a regional scale. Pp 257-288 in: Busch, D. E. and J.C. Trexler, eds. Monitoring ecosystems: interdisciplinary approaches for evaluating ecoregional initiatives. Island Press, Washington, D. C. $447 \mathrm{pp}$

McGeoch, M.A. (2007) The selection, testing and application of terrestrial insects as bioindicators. Biological Reviews, 73, 181-201.

Noss, R.F. (1990) Indicators for monitoring biodiversity: A hierarchical approach. Conservation Biology, 4, 355-364.

Rainbow PS, White SL. 1989. Comparative strategies of heavy metal accumulation by crustaceans: zinc, copper and cadmium in a decapod, an amphipod and a barnacle. Hydrobiologia 174: 245-262.

Rainio, J. \& Niemelä, J. Ground beetles (Coleoptera: Carabidae) as bioindicators. Biodiversity \& Conservation, 12, 487-506.

Reed, B.J., Hovel, K.A., 2006. Seagrass habitat disturbance: how loss and fragmentation of eelgrass Zostera marina ingludnces epifaunal abundance and diversity. Mar. Ecol. Prog. Ser. 326, 133-143. 
Short, F.T., Polidoro, B., Livingstone, S.R., Carpenter, K.E., Bandeira, S., Bujang, J.S., Calumpong, H.P., Carruthers, T.J.B., Coles, R.G., Dennison, W.C., Erftemeijer, P.L.A., Fortes, M.D., Freeman, A.S., Jagtap, T.G., Kamal, A.H.M., Kendrick, G.A., Judson Kenworthy, W., La Nafie, Y.A., Nasution, I.M., Orth, R.J., Prathep, A., Sanciangco, J.C., Tussenbroek, B. van, Vergara, S.G., Waycott, M. \& Zieman, J.C. (2011) Extinction risk assessment of the world's seagrass species. Biological Conservation, 144, 1961-1971.

Stoner AW. 1980a. Perception and choice of substratum by epifaunal amphipods associated with seagrasses. Marine Ecology Progress Series 3: 105-111.

Thomas, J.D. (1993) Biological monitoring and tropical biodiversity in marine environments: a critique with recommendations, and comments on the use of amphipods as bioindicators. Journal of Natural History, 27, 795-806. 
VITA

\section{JENNIFER LYNN SWEATMAN}

$\begin{array}{ll}2000-2004 & \begin{array}{l}\text { B.S., Biology } \\ \text { Texas A\&M University - Kingsville } \\ \text { Kingsville, Texas }\end{array} \\ 2005-2007 & \text { Peace Corps, Republic of Kiribati } \\ 2008-2010 & \begin{array}{l}\text { M.S., Biology } \\ \text { Texas A\&M University - Corpus Christi } \\ \text { Corpus Christi, Texas }\end{array} \\ & \begin{array}{l}\text { Doctoral Candidate } \\ \text { Florida International University } \\ \text { Miami, Florida }\end{array}\end{array}$

\section{PUBLICATIONS AND PRESENTATIONS}

Stoner, E., Yeager, L., Sweatman, J., Sebilian, S., and C. Layman (2014) Modification of a seagrass community by benthic jellyfish blooms and nutrient enrichment. Journal of Experimental Marine Biology and Ecology 461: 185-192

Stroud, J. T., M. R. Bush, M. C. Ladd, R. J. Nowicki, A. A. Shantz, and J. L. Sweatman (2015) Is a community still a community? Reviewing definitions of key terms in community ecology. Ecology and Evolution. DOI: 10.1002/ece3.1651

Sweatman, J. S. (May 2016) Amphipods as bioindicators. Paper presented at the Smithsonian Marine Station [Invited Seminar]. Ft. Pierce, Florida.

Sweatman, J. S. (March 2016) Seagrass beds in south Florida: plant-animal interactions under the sea, Presentation for the Florida Native Plant Society Miami-Dade Chapter [Invited Seminar]. Miami, Florida.

Sweatman, J. L., J. W. Fourqurean, and L. Collado-Vides (February 2016) Contribution of Penicillus (Chlorophyta, Bryopsidales) to organic carbon and $\mathrm{CaCO}_{3}-\mathrm{C}$ production across Florida Bay. Paper presented at the Florida Coastal Everglades All Scientists Meeting. Miami, Florida

Sweatman, J. L., C. A. Layman, and J. W. Fourqurean (November 2015) Disturbance mediated shift in resource limitation in seagrass ecosystems. Paper presented at the Coastal and Estuarine Research Federation. Portland, Oregon. 
Sweatman, J. L., C. A. Layman, and J. W. Fourqurean (November 2015) Disturbance mediated shift in resource limitation in an anthropogenically impacted seagrass ecosystem. Paper presented at the Benthic Ecology Meeting. Quebec City, Quebec.

Sweatman, J. L. (November 2013) Light and seagrasses in the Florida Keys: An "illuminating" analysis. Presentation for the Florida Gulf Coast University Department of Marine and Ecological Sciences lecture series. Ft. Myers, Florida.

Sweatman, J. L. and J. W. Fourqurean (November 2013) Relationship between light availability and benthic community structure in the Florida Keys. Paper presented at the Coastal and Estuarine Research Federation Meeting. San Diego, California.

Sweatman J. L. and J. W. Fourqurean (March 2013) Light attenuation in the FKNMS: patterns and mechanisms. Paper presented at the Benthic Ecology Meeting. Savannah, Georgia.

Sweatman, J. L. and K. Cammarata (March 2010) Seasonal and dose-dependent response of epiphyte accumulation on Halodule wrightii to experimental nutrient enrichment. Paper presented at the Texas Bays and Estuaries Meeting. Port Aransas, Texas.

Sweatman, J. L. and K. Cammarata (March 2010) Seasonal and dose-dependent response of epiphyte accumulation on Halodule wrightii to experimental nutrient enrichment. Paper presented at the Benthic Ecology Meeting. Wilmington, North Carolina.

Sweatman, J. L. and K. Cammarata (March 2009) Epiphyte accumulation on Halodule wrightii as an indicator of environmental conditions. Paper presented at the Benthic Ecology Meeting. Corpus Christi, Texas.

Thomas, P., and Sweatman, J. (2008) Interference by atrazine and bisphenol-A with progestin binding to the ovarian progestin membrane receptor and induction of oocyte maturation in Atlantic croaker. Marine Environmental Research 66:1-2 